\title{
VERHANIDELINGEI
}

VAN HET KONINKLIJK INSTITUUT VOOR TAAL-, LAND- EN VOLKENKUNDE

DEEL XIII

\section{DE REGERING VAN \\ PANEMBAHAN SÉNAPATI INGALAGA}

DOOR

Dr H. J. DE GRAAF

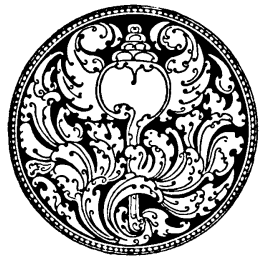

'S-GRAVENHAGE - MARTINUS NIJHOFF - 1954 



\section{INLEIDING.}

De geschiedenis der eerste Mataramse vorsten ligt nog geheel in de schemering. De beschrijver van Java's Hindoeïstisch verleden heeft gewoonlijk de pen reeds neergelegd, lang voordat hij aan de figuur van Sénapati zou zijn toegekomen; de Compagnies historicus beseft nauwelijks, dat zijn vaderlandse helden de bloei van een machtig Javaans rijk verstoorden, even oud als het Gemenebest der Zeven Verenigde Nederlanden. Zo kan het gebeuren, dat er in de handboeken of verzamelwerken nauwelijks een plaats voor Sénapati mag overschieten en het Mataramse huis pas in de persoon van sultan Agung toch nog vrij onverwacht ten tonele verschijnt. Aldus werd de $16 \mathrm{e}$ eeuw het verwaarloosde stiefkind in de Javaanse historie, gelegen als zij is tussen twee machtige veeleisende terreinen van onderzoek: de Javaanse archeologie en de koloniale geschiedenis.

Zelfs de Islamitici, die men zo gaarne de akker der z.g. „Mohammedaanse rijken" zag doorploegen, houden zich meestal verre van deze belangwekkende, maar ondankbare stof, terwijl de Javanici voorlopig nog het oog liever op oudere litteratuurproducten geslagen houden, dan op die van Nieuw-Mataram. Slechts enkelingen als Brandes en Rouffaer bestudeerden een of ander vraagstuk uit deze duistere periode. Waar zij aarzelend voorgingen, is behoedzaamheid dubbel geboden.

Toch lijkt het mogelijk, onze kennis van de 16e eeuw uit te breiden en ons inzicht daaromtrent te verdiepen. Nòg zijn niet alle verstrooide gegevens verzameld en behoorlijk gerangschikt. Met name lijken die in de Babad Tanah Djawi, onze hoofdbron niet in voldoende mate benut. Ook heeft m.i. de Sadjarah Dalem, het stamboomboek van ki PadmaSusastra, nog nauwelijks de aandacht getrokken, ofschoon het meer dan een halve eeuw geleden werd samengesteld.

Daarnaast beschikken Lands- en Koloniaal Archief over vele belangrijke, ongeraadpleegde stukken, terwijl in de bibliotheek van het Kon. Bataviaasch Genootschap een drietal voor deze periode nuttige handschriften op bewerking wachtte.

Dit oude en nieuwe, weinig of niet benutte materiaal lokte uit tot een poging, om de kloof, die tussen de $15 \mathrm{e}$ en $17 \mathrm{e}$ eeuw der Javaanse 
geschiedenis gaapt, niet zozeer te dempen, als wel ondieper te maken. $\mathrm{Na}$ volbrachte taak beseft men maar al te goed, dat hier nog zeer veel te doen valt, en dat menige conclusie door gebrek aan deugdelijke bronnen, slechts voorlopig mag heten.

Werpen wij, alvorens met het geschiedverhaal te beginnen, eerst een vluchtige blik op het Javaanse bronnenmateriaal, hetwelk een afzonderlijke beschouwing verdient. 


\section{DE BELANGRIJKSTE JAVAANSE BRONNEN.}

Ofschoon het in de bedoeling ligt in een ander verband de bronnen voor de Mataramse geschiedenis uitvoeriger te bespreken, dient hier toch het een en ander gezegd te worden over de voornaamste Javaanse bronnen voor het leven van Sénapati.

Het eerst trekt de aandacht de Babad Tanah Djawi. Het is er verre van af, dat wij oorsprong, bedoeling, middelen en samenstellende delen van dit hoogst merkwaardige geschrift reeds geheel zouden kunnen doorgronden. Voorlopig zij het voldoende op te merken, dat het zeker niet op eenmaal voltooid werd, doch dat verschillende handen er aan medegewerkt hebben. Zelfs in het proza-uittreksel, dat ons de z.g. Babad-Meinsma biedt, zijn deze met enige inspanning te herkennen.

Wat de betrouwbaarheid der gedeelten betreft, die aan onze held gewijd zijn, moet het betreurd worden, dat zo weinig daarvan aan de hand van buitenlandse gegevens kan gecontroleerd word. Echter verandert deze toestand vrijwel onmiddellijk, nadat de stichter van Mataram's grootheid de ogen gesloten heeft, door de komst der Nederlandse zeevaarders, wier berichten vooral chronologisch uiterst betrouwbaar zijn. Dan valt het op, dat de geschiedenis van Sénapati's opvolgers: panembahan Krapjak en sultan Agung, tot ongeveer 1635 in tamelijk goede volgorde verhaald wordt en dat de feiten vrij goed worden weergegeven. Dit wekt vertrouwen, niet slechts voor de periode van 1600 tot 1635, doch ook t.o.v. de daaraan vooraf gaande 20 jaar, dus van 1580 tot 1600 , aangezien de verteltrant van dit gedeelte in wezen niet verschilt van het volgende stuk. Vóór 1580 geeft de Babad ons helaas minder steun.

Een soortgelijke, zeer verwante bron is de Serat Kanda, in Nederlandse vertaling aangetroffen in de bibliotheek van het Kon. Bataviaasch Genootschap (Ms. no. 5404 dln.). Vrij zeker is het ms. afkomstig van de gouverneur van Java's Oostkust, Nicolaas Engelhardt en heeft hij het omstreeks het jaar 1807 uit het Javaans laten vertalen.

In hoofdzaak loopt het verhaal van deze Serat Kanḍa parallel met de bovengenoemde Babad, doch voor wat de tijd van Sénapati betreft, 
lijken sommige lezingen oorspronkelijker en ouder te zijn, minder fantastisch of romantisch uitgewerkt, nuchterder en zakelijker. Het aantal gegevens over personen is veel talrijker, terwijl de Javaanse auteur een bijzondere voorliefde koestert voor militaire zaken. Bovendien heeft hij zijn hart verpand aan Semarang e.o. zo mede aan de daar vereerde heiligen. Mogelijk komt deze Serat Kanḍa dan ook uit de kabupatèn van Semarang, waar Engelhardt in 1807 resideerde.

Terwijl de Babad Tanah Djawi en de Serat Kanḍa in onderwerp en opzet niet sterk verschillen, bestaan er gelukkig daarnaast nog bronnen, die een gans ander karakter dragen, m.n. de jaartallenlijsten.

Reeds Raffles onderscheidde in de Javaanse historische litteratuur deze lijsten van de eigenlijke kronieken en hij gaf er zelf een proefje van in zijn Chronological Table, waarin hij door J. Hageman werd gevolgd.

Behalve deze beide jaartallenlijsten benutten wij er nog twee, die slechts in handschrift worden aangetroffen in de bibliotheek van het Kon. Bataviaasch Genootschap: de Babad Sengkala en de Babad Sengkalaning Momana.

De eerste, die tot A.D. 1747 loopt, behandelt de Hindoe-Javaanse tijd zeer beknopt.

De andere, welks auteur genoemd wordt: pangèran aria SurjaNagara, reikt tot A.D. 1833 en is zeer uitvoerig over de oude mythische tijd. Vaak maakt hij daarbij van schema's gebruik, wat de gebruiker wantrouwig maakt.

Deze jaartallijsten vermelden heel wat méér feiten, dan de Babad of de Serat Kanda, soms over tijdperken, waarover de mededelingen overigens zeer schaars zijn, b.v. de tijd van Demak. $Z$ ij doen dit helaas in zo'n beknopte vorm, dat het, wanneer men de feiten niet van elders kent, soms meer raadsels dan gegevens zijn. Waren deze lijsten hulpmiddelen ter ondersteuning van het geheugen van vertellers? Verwonderlijk is ook, dat de meer verhalende bronnen zo weinig van deze jaartallijsten geprofiteerd hebben. Tot dusverre werden zij slechts zelden benut door moderne onderzoekers, het meest nog door G. P. Rouffaer.

De overige bronnen zullen in de loop van het verhaal besproken worden. 


\title{
KJAI GEDE SÉLA.
}

\author{
De oudste stamboom.
}

De stamboom der eerste Matarammers ziet er volgens de Babad (24-27) als volgt uit:

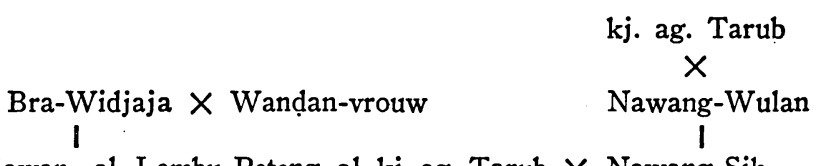

rd. Bonḍan-Kedjawan, al. Lembu-Peteng, al. kj. ag. Tarub $\times$ Nawang-Sih

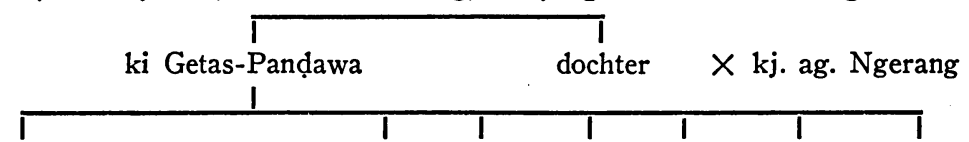

kj. ag. Séla njai ageng's: Pakis, Purna, Karé, Wanglu, Bokong, Adi-Baja

njai ageng's: Lurung Tengah, Saba, Bangsri, Djati, Patanèn, Pakis-Dadu, kj. ag. Ngenis

kj. ag. Pamanahan

Hiertoe past de volgende toelichting:

Rd. Bondan-Kedjawan is de zoon van Bra-Widjaja, laatste vorst van Madja-Pait en een Wanḍan-vrouw van zwart, donker ras, die hij, op aanraden van een nachtelijke stem, gehuwd heeft, om van een venerische ziekte af te komen (24).

Rd. Bondan Kedjawan wordt wegens een gevaarlijke voorspelling, bestemd om gedood te worden en daartoe aan een opzichter der rijstvelden, kj. bujut Masahar meegegeven. Doch op de voor de ter dood brenging bestemde tijd, wordt hij gespaard, dank zij het medelijden van Masahar's vrouw (24-25).

Later komt de jonge rd. Bonḍan Kedjawan met zijn pleegvader Masahar weer aan het hof, wordt door de vorst wel niet herkend, maar toch aangenomen en toevertrouwd aan $\mathrm{kj}$. ag. Tarub, die zijn naam in Lembu-Peteng verandert (28). 
Bondan Kedjawan alias Lembu-Peteng huwt daarna met de dochter van kj. ag. Tarub, geboortig uit een nimf Nawang-Wulan (33). Na de dood van zijn schoonvader wordt hij eveneens $\mathrm{kj}$. ag. Tarub genoemd en heeft dan pas gemeenschap met zijn vrouw Nawang-Sih, welke hem twee kinderen schenkt; ki Getas Panḍawa en een dochtertje, dat met kj. ag. Ngerang huwt.

Getas Panḍawa heeft zeven kinderen, alleen de oudste, kj. ag. Séla is een zoon, de overige zes zijn meisjes, de njai ageng's van Pakis, Purna, Karé, Wanglu, Bokong en Adi-Baja (33).

De enige zoon, kj. ag. Séla, verwekt wederom 7 spruiten, van welke ditmaal de jongste mannelijk is : kj. ag. Ngenis. De 6 meisjes heten de njai ageng's van Lurung-Tengah, Saba, Bangsri, Djati, Patanèn en Pakis-Dadu (47).

Deze kj. ag. Ngenis is ten slotte de vader van kj. ag. Pamanahan geworden, de eerste, wiens graf te Koṭa Geḍé in Mataram wordt aangewezen.

Tot zover de Babad Tanah Djawi, waarmede de Serat Kanda, ofschoon wat minder uitgebreid, overeenstemt. De Sadjarah Bantěn daarentegen vertoont belangrijke afwijkingen (p. 20). Bonḍan Kadjawan, zoon van Madja-Pait's eerste vorst, huwt er op raad zijner eerste vrouw een nimf, en daarna de dochter van kj. gedé Seséla. Uit het eerste huwelijk wordt een zoon Pandjoewed geboren, uit het tweede een zoon Pamanahan. $\mathrm{Na}$ de dood hunner ouders treden beiden in dienst bij de vorst van Padjang.

Kg. gedé Séla wordt in dit geschrift, hetwelk uit 1662-63 dateert, als een stamvader van moederszijde beschouwt, Daar een deel der gegevens in de Sadjarah Bantěn ontleend zijn aan een oudere vorm van de Babad Tanah Djawi, die vermoedelijk in de 2e helft der Regering van Sultan Agung geschreven is, zou het mogelijk zijn, dat ook deze opvatting omtrent kj. geḍe Séla in de oorspronkelijke Babad stond.

In dit vermoeden werden wij gesterkt, door een ,slacht reecqs”, in 1677 door de Mataramse hoveling Djaga-Pati opgegeven aan admiraal C. Speelman, waarin kj. geḍé Séla niet de grootvader van moederszijde is, doch slechts de schoonvader van $\mathrm{kj}$. geḍe Pamanahan, terwijl hij een „,man van staat” heet. Dus ook nu weer, behoort Séla tot de vrouwclijke lijn.

Is het verloop soms zo geweest, dat kj. geḍe Séla aanvankelijk helemaal niet tot het Mataramse geslacht behoorde, toch een plaats wist te verwerven in de vrouwelijke lijn, en eindelijk als rechtstreekse voor- 
vader werd erkend ${ }^{1}$ ). Van dit proces vinden we een parallel in Demak. Het geslacht dezer vorsten zal wel nooit, zomin van vaders- of moederszijde, iets te maken hebben gehad met het roemruchte huis van MadjaPait, aangezien het vermoedelijk uit Chinese (handels-?)kringen stamde. Welnu, in de oorspronkelijke Bantamse overlevering stammen de Demakse vorsten niet rechtstreeks van de Madja-Paitse koningen af, doch slechts van moederszijde. Pas de zoon van de ştamvader, Tjoetjoe geheten, kreeg na het verrichten van enige heldendaden, een MadjaPaitse prinses tot vrouw, uit welke dan de verdere vorsten stamden (Sadj. Bantěn 21-22).

In de latere Mataramse overleveringen daarentegen, waar de overeenkomstige figuren aria Damar en rd. Patah heten, zijn beiden bloedeigen zonen van de Madja-Paitse koning. Het ongetwijfeld oorspronkelijke Chinese element is nog slechts vertegenwoordigd door de vermaarde putri $T$ jina, die aria Damar tot vrouw krijgt, doch welke niet de moeder van rd. Patah wordt.

Wij veronderstellen dus, dat $\mathrm{kj}$. gedé Séla, er oorspronkelijk niet toe behorende, op den duur in de Mataramse stamboom ingeschoven is.

Gewoonlijk heten al deze kjai geḍé's naar een plaats ; zo ook kj. geḍé Séla. Dit Séla is niet het plaatsje Séla geweest tussen de bergen Merapi en Merbabu ingelegen, waar de Susuhunan een pasanggrahan en een groentetuin bezat, doch de desa Séla in het Groboganse, niet ver van Purwa-Dadi. Daar liggen ook kj. geḍe Séla en zijn beide echtgenoten begraven in de „Kradjang Séla”, waartoe een moskee en de woning van een djuru-kuntji behoren (Enc. N.I. s.v. Séla). Doch niet slechts de naam van $\mathrm{kj}$. geḍe Séla vinden we in het Groboganse terug.

Zijn vader heet volgens de overlevering ki Getas-Pandawa, of wel rd. Depok. Welnu, zowel een Getas als een Depok worden in de afdeling Grobogan aangetroffen.

Diens vader rd. Bondan-Kedjawan, of Lembu-Peteng, wordt ook, naar zijn schoonvader kj. ageng Tarub genoemd. Dit Tarub komt mede in Grobogan voor.

Ook de namen van enigen der vele dochters van Getas Pandawa en Séla zijn daar terug te vinden, b.v. Pakis en Bangsri. Het heeft er

1) In de Sadjarah Dalem, een vrij laat werk van ki Padma-Susastra (Sam. 1902), stamt volgens generatie $130 \mathrm{kj}$. geḍé Pamanahan niet slechts op de gewone rechtstreekse wijze van $\mathrm{kj}$. gedé Séla af, doch heet ook zijn moeder een nicht te zijn van „njai ageng Seséla Sepuh”. Er wordt terecht bij opgemerkt, dat dus kj. geḍé Pamanahan's beide ouders van dezelfde familie waren. Is dit een poging tot harmoniëring van twee overleveringen? 
inderdaad veel van, of men de sobere stamboom der Matarammers wat verrijkt heeft met de namen van plaatselijke, mythische figuren. Immers ook kj. geḍe Sęlla's zoon, kj. geḍe $\mathrm{Ngenis,} \mathrm{is} \mathrm{een} \mathrm{locale} \mathrm{groot-}$ heid, ditmaal niet in Grobogan, doch vlak naast de latere kraton van Padjang in Lawéjan, waar men hem zelfs de tjakal-bakal noemde.

Trachten wij thans de mogelijkheid na te gaan, of uit de berichten der overlevering iets zekers is vast te stellen, omtrent deze kj. geḍe Séla.

\section{Kjai gedé Séla volgens de overlevering.}

Het eerst treedt hij als leraar op (Babad 36-38) en Djaka-Tingkir, de latere vorst van Padjang, zit aan zijn voeten. De kennelijke bedoeling dezer episode is, er op te wijzen, dat zelfs de grote heerser over Padjang eens bij de Mataramse stamvader in de leer is geweest.

Belangrijker daarentegen lijken Séla's bemoeienissen met Demak (Babad 45):

Kj. ag. Séla wenst tamtama-soldaat (lijfwacht) te worden bij de sultan van Demak en als proefstuk slaat hij met één klap een stier de kop in. Toch wordt hij afgewezen, daar hij, beducht voor bloedspatten, het hoofd heeft afgewend.

Deze afwijzing brengt hem zo van streek, dat hij met gewapenden de kraton aantast. Hij komt te paard zelfs tussen de beide „waringin kurung” op de aloen-aloen. Zijn aanval mislukt jammerlijk, daar hij niet opgewassen blijkt tegen de nimmer missende pijlen van de sultan. Daardoor slaat zijn paard op hol, zodat het pas in Séla weer stil houdt.

De sultan doet dan deze raadselachtige uitspraak: „Het is duidelijk, dat onze vriend uit Séla vreesachtig is. Mij dunkt, dat hij geen vorst zal kunnen wezen. Maar ik weet niet, hoe het later zal zijn.

De Serat Kanḍa (388-95) heeft enige verschillen.

Zo noemt hij kj. ag. Séla een ,bediende" van de sultan. Om diens geweldige macht nog duidelijker te doen uitkomen, wordt medegedeeld, dat hij alléén de aanval stuit, ofschoon Séla zelfs met gevelde piek de pagelaran nadert. Met zijn pijlen schiet de sultan de buikgordel van het paard aan stukken, zodat dit opspringt en zijn berijder afwerpt. Daarna uit de sultan zich beslister dan in de Babad: „..... Misschien zal er indertijd een van uw nakomelingen wezen, die boven $U$ in heldenmoed zal overtreffen." Beschaamd druipt Séla daarop af naar zijn woning en voleindigt zijn tapa. Blijkbaar is hij te voorbarig geweest. 
Afgezien van de al te duidelijke voorspelling der Mataramse bloei in de laatste woorden van de Demakse vorst vervat, is het grootste bezwaar, dat wij tegen deze voorstelling koesteren, haar geringe oorspronkelijkheid. $Z \mathrm{ij}$ vertoont n.l. sterke gelijkenis met verhalen, die op naam van Djaka-Tingkir, stichter der Padjangse dynastie, staan. Deze biedt zich evenzo als tamtama-soldaat bij de vorst van Demak aan, zelfs tot twee maal toe.

Er bestaat dus aanleiding om te onderstellen, dat men ook de stamvader der Mataramse dynastie niet wilde laten achterblijven bij de befaamde Padjanger. Hij bedreef dezelfde heldendaad, n.l. het doden van een buffel met één klap, doch werd tòch nog, om een kleinigheid, afgewezen. Gewapend verzet daartegen baatte natuurlijk niet, doch de fraaie voorspelling vergoelijkt veel. Deze geschiedenis is blijkbaar een handig bedacht verzinsel.

Voorts bezitten wij nog enige verhalen, die er zó legendarisch uitzien, dat zij bezwaarlijk historische feiten kunnen weergeven, (Babad 46-47), wier inhoud wij niet zullen weergeven. Het zijn: kj. ageng Séla en de bliksem; dezelfde en het slagbekken kj. Bitjak; ten slotte deze persoon en enige taboe's. Deze geschiedenissen ontbreken in de Serat Kanda, waarin wij daarentegen een andere legende aantreffen. Wij vermelden deze, niet om haar waarheidsgehalte, doch enkel, omdat een herinnering er aan zich in de Demakse moskee bevindt (p. 381-83).

Bij de dood van pg. Sabrang Lor van Demak verzamelden zich alle wali's en mindere geestelijken in de grote moskee en na de Vrijdagsgodsdienstoefening begaven zij zich naar de ,galderij” van de „Tempel”, ter verkiezing van een nieuwe vorst. Onderwijl verspreidde zich in de lucht een donkere wolk onder zwaar onweder en bliksems. Toen verscheen aldaar "Gede Selo". Deze werd wel door de bliksem geraakt, doch hij pakte hem aan en gaf hem over aan de wali's, die er een afbeelding van maakten aan de Noordpoort van de tempel. Vervolgens baden zij de Almachtige vuriglijk, dat de moskee voor blikseminslag bewaard mocht blijven.

Men vindt thans nog aan de Demakse moskee een fantastische figuur afgebeeld, kj. geḍé Séla voorstellende, welke reeds Raffles vermeldt.

Echter kan men niet zeggen, dat de oogst aan vaststaande historische feiten aanzienlijk is.

Pigeaud acht het daarom in zijn Volksvertoningen (par. 372) zeer wel mogelijk, deze kjai gedé te beschouwen als een mythische voorvader of godheid, die oudtijds in verband werd gebracht met vuur en bliksem. 
Inderdaad speelt vuur bij het huidige ceremonieel aan het graf in Séla nog altijd een zekere rol.

\section{Het vuurceremonieel.}

Voor Garebeg Mulud kwam er een kratondienaar het heilige graf bezoeken en ontstak er een reep klapperbast aan de daarboven steeds brandende lamp. Vervolgens werd dit „eeuwige vuur” Solowaarts gebracht en daarmede een lamp binnen het sacrale huis van de Kraton ontstoken, welke dan weder een jaar achtereen ononderbroken moest branden. Aldus mijn bereidwillige berichtgever dr. Poerbatjaraka.

Een enigszins afwijkende voorstelling van dit gebruik verstrekt $B$. Schrieke in zijn bijschrift bij F. D. K. Bosch' artikel: Het lingga-heiligdom van Dinaja (T. B. G. LXIV, 227-85), waarin hij mededeelt, dat tweemaal 's jaars een weinig van het Sélase hemelvuur naar de Kraton te Solo werd overgebracht, waar het bij de vorstelijke kobongan werd geplaatst. „In vroeger dagen zou deze overbrenging met een grote processie.. zijn gepaard gegaan, die ook anderen (b.v. de pangéran's) in de gelegenheid stelde, het lampje hunner kobongan opnieuw aan het vuur van Séla te voorzien" (p. 290-91). Schrieke betoogt dus, dat het Séla-se vuur feitelijk ,het glanzend beginsel der heerschappij” voorstelt.

Doch waarom, zo vraagt men zich af, begeerden de Mataramse vorsten dit hemelse vuur nu juist uit Séla te ontvangen?

Het eerste heeft zich, bij mijn weten, W. F. Stutterheim met deze vraag bezig gehouden in zijn: A Javanese Period in Sumatran History, Surakarta 1929. Hij wees er op, dat de desa Séla in de nabijheid ligt van de plek, waar de traditie de ligging van het geheimzinnige Mendang Kamulan zocht. Raffles trof er nog de overblijfselen van een oude kraton aan. In kjai ageng Séla, dat hij door ,de grote heilige van Séla" vertaalde, zag Stutterheim een Çailendra-vorst. Çailendra splitste hij in : Çaila (Oud-Javaans voor Séla) en Indra, de hemelgod, die de bliksem voert.

Hierbij dient echter te worden opgemerkt, dat niet steeds kjai gedé grote heilige beduidt, doch vaak een meer wereldse betekenis heeft. Of de volksoverlevering de personen der Çailendra's inderdaad zich zo scherp zou herinneren, als Stutterheim meent, valt m.i. te betwijfelen. Wellicht bestond er niet meer dan een flauwe notie, ondersteund door nog aanwezige bouwvallen, dat hier eens het middelpunt van een groot rijk geweest was, zonder dat men zich een bepaald persoon helder voor ogen stelde. 
Schrieke noemde in zijn binnenkort te verschijnen „Studiën over vorst en rijk op oud Java" in verband hiermede ook de anwezigheid van ,slijkvulkanen, zoutbronnen en het eeuwige vuur, dat uit de grond te voorschijn komt". Inderdaad zou dit het vunrachtige karakter van de kjai geḍe Séla-figuur wel enigszins verklaren. Daar de streek te onvruchtbaar was voor een kraton, dacht Schrieke ook aan het bestaan van een dynastiek heiligdom in Séla. Tevens wees hij er op, dat ook $\mathrm{kj}$. ageng Tarub, kj. agung Séla's grootvader, in zijn naam herinnert aan een plaats, die reeds in de Hindoe-Javaanse tijd vermaard was, t. w. het ,aloude Tarub van Sanjaya” (Krom, Hindoe-Jav. Gesch. 2e dr. p. 191).

Dit zij voldoende, om het kunstmatig karakter van de kj. gedé Sélafiguur op de voorgrond te stellen.

Doch er bestaat nòg een bijzondere reden, waarom de Mataramse dynastie begeerde aan te knopen bij de vage herinneringen aan een groots verleden, waartoe de Javaanse geest wel meer neiging heeft.

De voorafgaande dynastie, die van Padjang, deed n.l. hetzelfde, vermoedelijk reeds eerder. Haar held, Djaka Tingkir, heet naar het plaatsje Tingkir, hetwelk, naar Schrieke meent, eveneens een historische plek is, daar het niet ver van een der bronnen van de kali Senjaya gelegen is.

Ook later blijkt er nog een nauwe staatsrechtelijke verbinding tussen Séla en de Vorstenlandse kratons te bestaan.

Toen de Vorstenlanden na de Java-oorlog zo sterk werden ingekrompen, bedongen de Sunan en Sultan bij contract van 27 Sept. 1830, dat de „Heilige graven van ... Seselo in het Soekowatische ... het eigendom van de beide vorsten (zouden) blijven". Voor het onderhoud dezer graven zouden ,twaalf Jonken (=djung) land aan Z. H. den Sultan van Djogjakarta in de nabijheid derzelven voor het onderhouden .... aangewezen worden" (P. W. Filet, De verhouding der vorsten op Java tot de N.I. Regering p. 288-89).

Volgens Van Hoëvell (Reis over Java enz. I, 120) betaalde de Susuhunan jaarlijks f 100 per jaar voor het onderhoud der graven, welke zich bij zijn bezoek (in 1847) in een armzalige toestand bevonden.

De enclave Séla is bij contract van 14 Jan. 1902 opgeheven. Echter waren van de koop door het Gouvernement uitgesloten de graven met de moskee en wachterswoning, die voor rekening der zelfbestuurders werden onderhouden (Encyclopaedie ibidem).

Een en ander toont het belang aan, dat men in de Vorstenlanden ge- 
durende de laatste eeuwen aan het landje Séla hechtte, en zou inderdaad in de richting van een krachtige overlevering kunnen wijzen.

De Matarammers volgden dus die van Padjang niet slechts na, door voor hun kj. gedé Séla-figuur de historische Djaka-Tingkir als voorbeeld te nemen, doch ook door aan te knopen bij een plaats, vermaard in de Javaanse herinnering. Ja, ze overtroffen zelfs de Padjangers door een plek te kiezen, welks verleden nog verder terug zou liggen, dan de figuur Sandjaja, n.l. die van het heilige Menḍang Kamulan.

\section{De Séla-traditie en Mataram.}

Séla nam reeds lang een bijzondere plaats in binnen het Mataramse rijk.

Op een lijst met opgaven van belastingen, waartoe alle gewesten des rijks verplicht zouden wezen, en welke uit het jaar 1638 moet dateren - men vindt haar opgenomen tussen de jaartallen van de Babad Sangkalaning Momana (Ms.) - komt onmiddellijk ná Mataram (JogjaKarta) en Padjang (Sura-Karta) ook het nietige Séla als afzonderlijk gewest voor, ofschoon dit kleine landje slechts 500 tjatjah's telt, tegen Mataram en Padjang respectievelijk 41.345 en 25.380. Het grotere getal der Mataramse dienstplichtigen zou er inderdaad op kunnen wijzen, dat dit bericht nog uit de tijd van Mataram, dus van vóór 1680 is.

Als afzonderlijk gebied verschijnt Séla ook in het Dagregister van Antonio Hurdt (van 5 Sept. 1678 tot 2 April 1679), behelzende zijn verrichtingen tegen de opstandige rd. Truna-Djaja. Onder 16 Sept. 1678 vermeldt deze superintendent, dat "die van Cecela" zich waren komen vernederen voor hun heer, sunan Mangku-Rat II.

Vraagt men, wie deze op een fictie berustende traditie in het leven hebben geroepen, en wanneer, dan wordt men onwillekeurig toch gedreven in de richting van de eerste samenstellers der Mataramse Babadstof, de heren van Adi-Langu, die omstreeks het einde van sultan's Agung's regering aan het werk zijn geweest. Véél vroeger kon niet, want in de verhalen van kj. gedé Séla is onder meer materiaal verwerkt, ontleend aan de Padjangse traditie, die toch niet eerder dan in het begin van de $17 \mathrm{e}$ eeuw kan zijn ontstaan. Later kan evenmin, want vóór 1662/63 blijkt kj. geḍé Séla reeds in de Mataramse familie, zij het nog slechts in de vrouwelijke lijn, te zijn opgenomen.

Bovendien is de afstand Adi-Langu-Grobogan niet zo groot, dat de faam van Séla de nazaten van sunan Kali-Djaga zou zijn ontgaan. 
Toch zou ik er voor terugdeinzen, om àlle rechtstreekse verbindingen tussen het van ouds vermaarde Séla en de Mataramse dynastie voor ongerijmd te verklaren. De merkwaardige $\mathrm{kj}$. geḍé Séla moge een bedenksel blijken, de meermalen in de Babad vermelde lieden van Seséla (p. 59 en 63) lijken moeilijker thuis te brengen. 150 Hunner, familieleden van $\mathrm{kj}$. gedé Pamanahan, volgen hem naar het pas verworven Mataram, nadat zij hem tegen Djipang hebben bijgestaan, tenzij men deze 150 getrouwen als een opzettelijke imitatie beschouwt van de „honderd menschen”, die rd. Susuruh volgen op zijn vlucht uit Padjadjaran naar het rijk Singa-Sari (Babad 16-17)!

Evenwel, er lopen nog meer lijnen van Séla naar de Vorstenlanden. De maskerspelers van Palar (bij Klatèn) geven ook een herkomst uit Séla op (Pigeaud, Volksvertoningen par. 16, 27 en 366).

\section{Oudste Nederlandse berichten.}

Laat ons thans zien, of uit de oudste Nederlandse berichten nog iets te halen is. Deze mededelingen verdienen niet de voorkeur om hun oorspronkelijkheid, daar zij alle op meest ongenoemde Javaanse berichtgevers teruggaan, doch enkel op grond van hun hoge ouderdom, welke die der Babad-eindredactie overtreft.

Het eerste bericht is afkomstig van niemand minder dan van Jan $P z$. Coen en wordt aangetroffen in zijn „Vertoogh van de staet der Vereenichde Nederlande in de quartieren van Oost-Indien" (Kron. Hist. Gen. 1853, p. 126-27), waar men leest, dat de grootvader van de toenmalige vorst van Mataram (sultan Agung) was ,een gemeen man uyt een dorp Mataran... beteldrager van coninch Paty, welcke neuens de cloecheyt in wapenen ende verstandt, 't geluck hadde, dat van geringe staet tot heerschappie over veel volckeren ende coninckrijcken geraect is ..."

Terecht veronderstelt H. Djajadiningrat in zijn proefschrift (p. 283), dat Coen grootvader en overgrootvader van sultan Agung verwart, dus Sénapati met $\mathrm{kj}$. geḍé Pamanahan, wat een vergeeflijke fout is, die meer voorkomt. Doch verder lijkt Paty, welks ,coninck” (Bescheiden I, 374) Coen kende, in de plaats getreden van het hem wschl. onbekende Padjang, in welk geval de mededeling zou slaan op de periode omstreeks 1575 , toen kj. geḍe Pamanahan nog een vazal was van de vorst van Padjang. Aldus verspreidt dit oudste bericht geen licht over het allereerste begin der Mataramse grootheid. 
Dan hebben wij nog twee verhalen, resp. van de opperkoopman Jacob Couper en van de bekende predikant ds. François Valentijn. Beide vertonen sterke overeenkomst, zijn zeer waarschijnlijk op West-Java opgevangen, dragen daarom een voor Mataram weinig vleiend karakter, en zijn helaas jonger dan het ontstaan van de oudste Babad, zodat zij daaraan kunnen ontleend hebben. Daar Couper's verhaal een zeer storende fout vertoont, beginnen wij met Valentijn (IV, 72).

Volgens Valentijn was de eerste der Mataramse keizers Siroeboed, waarin wij Sénapati's jeugdnaam radèn Bagus Srubut herkennen (Sadjarah Dalem gen. 131,2). Echter verhaalt Valentijn ook feiten van hem, die zeker tijdens zijn vader voorvielen. In Siroeboed zal dus de ganse voorgeschiedenis der Matarammers samengevat zijn.

Over hem deelt Valentijn mede: „Deze was geen Keizer, nog Koning, maar een slaaf van den Sultan van Damak, die gewoon was gras voor zyn paarden te haalen. Hy, eenig quaad omtrent de bywyven van den Sultan bedreven, en gehoord hebbende, dat die Vorst hem dooden wilde, nam de vlugt na den Sultan van Padjang..., die als een goedaardig Vorst hem in zyn dienst aannam, en een vrouw, een huis, en rystvelden gaf." Tot dank stal hij de goederen van die vorst, ja zelfs zijn bijwijven, zodat zijn leven gevaar liep.

Ook Jac. Couper, begint met Srubut zijn „Verhael van het geslagt der Cheribonse princen" enz., dat te vinden is in het onuitgegeven Dagregister van 1 Oct. 1684 (L.A.). Naar hij zelf mededeelt, vernam hij het in Tjerebon, toen hij daar jacht maakte op de avonturier Sura-Pati.

Daar Couper zijn „Sroeboet” tevens kj. geḍe Mataram noemt, is er, evenals bij Valentijn, ook Sénapati's vader mede bedoeld. Deze was eveneens een „slegt Javaen, een dienaer of grashaelder”, echter niet in dienst van de vorst van Demak, doch in die van de vorst van Padjang. $\mathrm{Na}$ op overspel betrapt te zijn met een van des sultans bijwijven, vindt hij een schuilplaats in Demak, totdat hem ook in die plaats wegens een of andere misdaad, de grond te heet onder de voeten wordt. Daarop wordt hij roverhoofdman, vermeestert de „negorij Mataram” en noemt zich daarnaar.

Couper heeft blijkbaar Demak en Padjang verwisseld. Herstelt men deze fout, dan vertoont zijn verhaal met dat van Valentijn sterke gelijkenis. Het zijn, buiten de Mataramse traditie, waarvan zij wellicht iets gehoord kunnen hebben, de enige aanwijzingen voor een bemoeienis der oudste Matarammers met Demak. Zij leggen daarom weinig gewicht in de schaal. Doch belangrijker wordt hun getuigenis, wanneer zij, in overeenstemming met het bericht van Coen, aan de Matarammers een 
zeer eenvoudige herkomst toeschrijven. Bij Coen: een beteldrager; bij Valentijn: een slaaf; bij Couper: een dienaar of grashaalder. Wij vermogen niet aan dit drievoudig, eensluidend getuigenis, dat in de Babad of Serat Kanḍa ontbreekt, zonder meer voorbij te gaan. Dit is een zeer oude, zeer waarschijnlijk op zekere realiteit teruggaande overlevering, die in flagrante strijd is met een afstamming van kj. geḍe Séla, waarvan in hofkringen hoog werd opgegeven. Het valt niet te ontkennen, dat naar mate de herkomst uit het roemrijke Seséla onaannemelijker wordt, de proletarische afstamming der Matarammers aan waarschijnlijkheid wint. 


\title{
DE LIEDEN VAN SÉLA IN PADJANG.
}

\author{
Overleveringen omtrent Djaka-Tingkir.
}

Gelijk $k j$. ageng Séla, zij het ook kort, verbonden zou zijn geweest aan de opkomst van Djaka-Tingkir (Babad 37), zo zou de daarop volgende grote Matarammer, kj. geḍe Pamanahan getuige wezen van diens grootheid als vorst van Padjang, terwijl diens zoon Sénapati mede zou werken aan zijn val en ondergang. Aldus laat de overlevering de opkomst van het Mataramse geslacht met opzet evenwijdig lopen met de kortstondige groei, bloei en ondergang van het Padjangse rijk.

Wanneer wij kj. geḍé Pamanahan voor het eerst in de Padjangse historie zien ingrijpen, dan heeft de Padjangse vorst reeds een lange en wisselvallige loopbaan achter de rug. Het lokt ons niet aan, hem hierop stap voor stap te volgen. Vooreerst ligt Padjang's opkomst enigszins buiten de lijn van ons betoog en voorts zijn de bezwaren, om uit de verwarde overlevering wijs te worden, al te groot. Wij weten slechts, dat de wonderverhalen over 's vorsten jeugd op gebeurtenissen moeten slaan, welke vóór 1546 hebben plaats gevonden. Toen immers kwam volgens de vindingrijke Portugees Pinto voor de muren van Panarukan de laatste vorst van Demak door jeugdige moordenaarshand droevig om het leven, en het was waarschijnlijk aan het hof van deze vorst, in de Javaanse overlevering Trenggana genaamd, dat de jeugdige Djaka-Tingkir zo'n merkwaardige opgang maakte.

Hierover vertelt de Babad (35-46) het volgende:

Djaka-Tingkir zou geboren zijn in het geheimzinnige Pengging, dat een zelfstandig staatje moet geweest zijn (35). Men vindt er enige hindoeïstische oudheden, zo mede een heilig graf, toegekend aan Djaka-Tingkir's vader Kebo Kenanga, alias Andajaningrat. Aan zijn geboorte tijdens een wajang bèbèr-voorstelling (ook wajang krèbèt genaamd) dankt hij de naam van mas Krèbèt.

Djaka-Tingkir werd evenwel niet in Pengging opgevoed, doch te Tingkir, daar sunan Kudus, priestervorst - diplomaat - generaal van Demak, zijn vader wegens diens wederspanningheid vermoord had en zijn moeder kort daarop gestorven was. Zijn familie had hem toen naar Tingkir overgebracht, waar een rijke weduwe van 
een vriend zijns vaders hem verder verzorgde. Vandaar zijn naam Djaka-Tingkir, de knaap uit Tingkir, gelijk hij allerwegen in de Vorstenlanden geliefd en vermaard is.

Zijn leertijd bij kj. ageng Séla roerden wij reeds aan. Diens gelukkige dromen over zijn leerling slaan wij over (37). Ook met een andere Mataramse heilige maakte hij kennis, n.l. met de befaamde sunan Kali-Djaga, die hem raadde, dienst te nemen bij de sultan van Demak (38).

Djaka-Tingkir volgde deze raad en bood zich aan als tamtama, lijfwacht. Door achteruit over de moskee-vijver te springen zonder opzet, hij moest onverwachts voor de sultan en de zijnen uitwijken - toonde hij aan, de geschikte man te wezen, en hij werd hoofd der tamtama's (39).

Enige tijd later vroeg dit corps om uitbreiding. Een candidaat, geen Adonis, mishaagde aan de jeugdige kommandant. Derhalve onderwierp deze hem niet aan het gebruikelijke examen: het verbrijzelen van de kop van een stier met de vlakke hand, doch stelde, met toestemming van het slachtoffer, diens onkwetsbaarheid op de proef. Djaka-Tingkir had echter genoeg aan een haarnaald, om diens hart te doorboren, zo groot was zijn sekti! Doch dit had meteen zijn ontslag en verbanning ten gevolge, hoe zeer zijn kameraden ook zijn vertrek betreurden.

Moedeloos keerde Djaka-Tingkir terug en verlangde te sterven (40). Twee kluizenaars, kj. ageng Butuh en Ngerang onderwezen hem niet slechts, doch staken hem ook een hart onder de riem. Tijdens een nachtelijk bezoek aan zijns vaders graf in Pengging verwees een stem hem weer naar andere heilige mannen o.a. naar kj. Bujut van Banju-Biru, die hem verder onderrichtte. Zo schonk deze hem een tovermiddel om opnieuw de gunst van de sultan te verwerven. De reis terug naar Demak ging per vlot, getorst door 40 krokodillen enz. (40-43).

In Demak paste hij het geleerde tovermiddel toe. Een wilde buffel werd dol gemaakt, zodat zelfs de tamtama's hem de kop niet konden verbrijzelen en het smadelijk aflegden, drie dagen en nachten lang. Slechts Djaka-Tingkir gelukte het de buffel te doden, n.l. door eenvoudig het in de bek gestopte tovermiddel er uit te nemen. Hij werd daarop in zijn oude ambt hersteld (44-45).

Enige tijd later mocht hij 's vorsten 5e dochter huwen en werd bupati van Padjang met een apanage van 4000 bouw. Elk jaar moest hij zijn opwachting maken, doch het land bloeide en hij bouwde er zich een paleis (46).

Dit zijn zo Djaka-Tingkir's lotgevallen vóór de dood van sultan Trenggana in 1546, gelijk de Babad Tanah Djawi die ons beschrijft.

De historicus vermag hier voorlopig nog weinig aan toe te voegen. Het heeft er echter de schijn van, alsof de verbinding met het vermaarde Pengging toch wel uiterst dun is. Waarom wordt Djaka-Tingkir 
geen Djaka-Pengging genoemd? Heeft men deze jongeling uit Tingkir met opzet een luisterrijke stamboom willen verschaffen? De. Sadjarah Bantěn (28-29) wil van Pengging niets weten en noemt Djaka Tingkir's vader eenvoudig een krokodil. Over het Hindoe-Javaanse verleden van Tingkir zie men hiervoren.

Voorts is de dubbele inwijding door heilige mannen en de tweevoudige reis naar Demak er één te veel. De eerste tocht derwaarts wordt ook voorbereid door kj. geḍe Séla en sunan Kali-Djaga, voorvader en beschermheilige der Matarammers. Op grond van dit Matarams karakter zou men het eerste bezoek aan Demak kunnen zien als een latere toevoeging uit Mataramse pen. De oorspronkelijke reis Demakwaarts zou dan de tweede zijn, waarbij ook heilige mannen uit het Padjangse (Sura-Karta) een rol van betekenis spelen.

Trouwens in de Sadjarah Bantĕn (29) wordt ook maar één reis van Djaka-Tingkir naar Demak vermeld, met sterk afwijkende bijzonderheden. Overigens is het niet de gewoonte der volksoverleveringen om te verdubbelen, doch eerder om te vereenvoudigen. Twee reizen naar Demak moeten dus wijzen op invoeging of opzettelijke combinatie. Dit zou een aardig voorbeeld er van kunnen zijn, hoe een oorspronkelijk Padjangs verhaal Matarams geworden, of liever opzettelijk gemaakt is.

Nemen wij dus voorlopig aan, dat Djaka Tingkir niets met Pengging had uit te staan en dat hij door in dienst te treden bij de vorst van Demak, Trenggana, zijn fortuin gemaakt heeft. De Sadjarah Bantěn schrijft hem ook een buitengewone vlugheid toe. Niet alleen, dat hij op jacht de herten voor zijn heer inhaalde en ijlings thuis bracht, doch hij verraste deze daarna ook met een nog warme sirihpruim, afkomstig van de lippen der sultane! Schuilt er in dit verhaal spotternij?

Bedenkelijker lijkt, dat hij volgens de Serat Kanḍa (437) zijn nieuwe dalem in Padjang maakte naar het voorbeeld van die in Demak.

\section{Padjangse oudheden.}

Wat ten slotte de plaats Padjang zelve betreft, dit was in deze tijd enigszins een middelpunt van cultuur. Op de plek, waar de bevolking de kraton aanwijst - tot in onderdelen toe! - worden thans nog massa's baksteenpuin gevonden, die de grond daar ietwat rood kleuren.

Bovendien treft men er duizenden scherven Chinees en Zuid-Oost Aziatisch aardewerk aan, welke door de Heer E. W. van Orsoy de Flines gedateerd werden van de $13 \mathrm{e}$ eeuw af tot de eerste jaren der 17 e eeuw. In die tijd leefden daar dus lieden, rijk en beschaafd genoeg, 
om zich de weelde van ingevoerd aardewerk te kunnen veroorloven. Dit feit ondersteunt dus dr. Stutterheim's hypothese, dat de in de Nāgarakrtāgama herhaaldelijk genoemde leenvorst van Padjang inderdaad in het thans als zodanig bekend staande Padjang zou gewoond hebben.

Voorts werden daar in 1940 bij het graven van een één à twee meter diepe greppel bakstenen fondamenten bloot gelegd, waarvan de stenen niet door kalk of cement verbonden waren. Op naburige erven werden bijzonder grote bakstenen aangetroffen, die volgens de eigenaar, opgedolven waren. Als enigst monument boven de grond staat er een nauwelijks geornamenteerde, kubusvormige steen, die dr. Stutterheim een yoni noemde, doch welke de bevolking verslijt voor de stenen voet van een reusachtige pendapa-stijl. Ten slotte wijst men in de nabijgelegen kali nog een plek aan, waar wijlen de sultan zich met tapa zou hebben onledig gehouden. Dat de zwoele verbeelding der brave tani's ook van een kaputrèn afweet, behoeft nauwelijks vermelding.

Dit Padjang nu was het middelpunt van een rijk, dat zich korte tijd over een groot deel van Java uitstrekte. Rouffaer leverde voor het bestaan van dit rijk het bewijs door zijn belangrijk artikel in het AlbumKern (1903) p. 267-74: Een duistere plaats van Java's staatkundige toestand tijdens Padjang... opgehelderd, waarvan hij de inhoud herhaalde in het artikel: Padjang van de Encyclopaedie van N.I. III, $244-45$.

\section{De verhuizing van Ngenis.}

Aan het Padjangse hof zouden zich, aldus de Mataramse overlevering, lieden bevonden hebben, die daarheen uit Séla waren overgekomen. Een drietal hunner verdient de aandacht. Allen staan in verbinding met kj. ageng $N g e n i s$, de zoon van de kj. geḍe Séla, over wie wij in het vorige hoofdstuk spraken. Het zijn de volgende figuren: (Babad 47-48) :

De eerste is Ngenis' zoon, kj. geḍe Pamanahan, gehuwd met de oudste dochter zijner tante, nj. gedé Saba, dus met zijn nicht.

De tweede is kj. Djuru-Martani, een zoon van deze nj. geḍe Saba. Daardoor was hij zowel neef als zwager van kj. gedé Pamanahan.

De derde wordt een aangenomen zoon van kj. geḍe Ngenis genoemd, een bloedverwant in de eerste graad (ook wel: neef S.K. 441). Hij heette slechts ki Pandjarri. Stellig was hij niet de minste, daar hij, niettegenstaande zijn eenvoudige positie, toch als een broeder der eerste twee werd behandeld. Wij komen op hem terug. 
Vrij uitvoerig verhaalt de Babad (48), hoe deze lieden uit Séla in Padjang kwamen.

Het genoemde, onafscheidelijke drietal, ging in de leer bij sunan Kali-Djaga, waar ze als mede-leerling de sultan van Padjang aantroffen. Op verlangen van hun leraar werd deze als broeder der drie uit Séla beschouwd, hetgeen vlot verliep.

Volgens de wens van de sultan verhuisde kj. gedé Ngenis naar Padjang, waarheen hem ook de anderen natuurlijk volgden. $\mathrm{Na}$ lange tijd overleed Ngenis in zijn woonplaats Lawijan, waar hij ook begraven werd.

Pamanahan en Pandjawi vielen bij de sultan zo in de smaak, dat zij aanvoerders der tamtama's werden. De vorst noemde hen zelfs „oudere broeder”. Kj. Djuru-Martani's werk was slechts het leiding geven aan de eerste twee.

De Serat Kanḍa (441-42) is veel beknopter en verkleint sunan Kali-Djaga's rol. Kj. geḍé Ngenis begeeft zich eenvoudig met zijn ganse familie in dienst van de nieuwe vorst van Padjang, bij wie hij zo in de smaak valt, dat hij Lawijan ten geschenke ontvangt. $\mathrm{Na}$ zijn dood aldaar worden kj. Pamanahan en Pandjawi lurah's over de tamtama's.

Tegen bovenstaande overleveringen pleit echter, dat de Sadjarah Bantĕn kj. geḍe Ngenis evenmin vermeldt als Speelman's zegsman Djaga-Pati. Waar dus deze 17 e eeuwse bronnen over Ngenis zwijgen en zelfs de traditie nauwelijks een enkel feit uit zijn leven weet te melden, daar ligt de onderstelling voor de hand, dat deze vage figuur een bedenksel is van Karta-Surase geleerden, zodat hij pas opduikt in een vorstenlijst van 1741. De nabuurschap van Lawijan zal zijn introductie tijdens de kraton van Karta-Sura in de hand hebben gewerkt. Met hem zou ook de verhuizing uit Séla naar Padjang verdwijnen. Hierop zinspelen wel de bij Couper en Valentijn aangetroffen verhalen, doch daar Ngenis' naam hun onbekend is, blijven hun voorstellingen uiterst vaag.

De sterkste aanwijzing voor Ngenis' verhuizing zou zijn naam kunnen wezen, indien men deze ten minste mocht vertalen als „de uitknijper” d.w.z. uit Séla. Doch deze naam kan ook „de oudere, wijlen” beduiden, waarmede dit argument vervalt.

In elk geval rust kj. geḍe Ngenis met vele andere groten, onder welke de rampzalige sunan Paku-Buwana II, op een zeer weidse begraafplaats achter de moskee van Lawijan. Een enkele maal wordt hij wel naar deze plaats genoemd en de bewoners beschouwen hem ook als hun tjakal-bakal. 
Ngenis' vrouw rust echter, merkwaardigerwijze, niet aan zijn zijde, doch aan het hoofd der vorstengraven te Kuṭa Geḍé. Men zou dit kunnen beschouwen als een krachtig argument ten gunste van 's mans veronderstelde plaats in de Mataramse stamboom, indien wij omtrent deze aanwijzing zekerder waren. Doch, gelijk zo vaak, is het grafmonument naamloos. Bovendien pleit tegen de echtheid van dit graf, dat het in een nis van het grote grafhuis ligt, waarvan men zou vermoeden, dat hij er later tegen aangezet is, ten einde de Mataramse stamboom nog één geslacht hoger op te voeren. Nauwkeurige onderzoekingen ter plaatse naar stijl en materiaal van het grafteken zouden hier wellicht een oplossing kunnen geven, als de toestand van het monument dit nog vergunt. Immers in het begin dezer eeuw is het grafhuis in vlammen opgegaan en daarna in ietwat pronkerige stijl vernieuwd.

Met het wegvallen van $\mathrm{kj}$. gedé Ngenis behoorde de familieband tussen Pamanahan, Djuru-Martani en Pandjawi te breken. Daar staat echter weer tegenover, dat er toch tal van aanwijzingen in de traditie zijn, dat deze drie met elkander verwant waren. Djuru-Martani wordt herhaaldelijk door Sénapati oom genoemd (B.T. Dj. 75, 76, 79, 94, $102,107,114)$, treedt op als voogd over Sénapati en zijn broeders (ibid. 72) en installeert zijn opvolger (ibid. 117). De laatste twee functies komen inzonderheid familieleden toe. Zijn kleinzoon ManduraRedja (Babad 121) draagt de pangéranstitel, welke naar Mataramse opvattingen bijzonder prinsen van den bloede toekomt (d.J. IV, 292).

Dat Pamanahan en Pandjawi (hier: Pandjoewed), verwanten waren, meent ook de Sadjarah Bantěn (p. 20), die hen halve broeders noemt. Sénapati's wilde zoon rd. Rangga noemt de dipati van Pati, Pandjawi, zijn oom (Babad 100). Doch bovenal wijst op verwantschap het verhaal over de dood van Pandjawi's zoon Pragola (I) door toedoen van Sénapati. Op drieërlei wijzen wordt daarin de onschuld van Sénapati betoogd, hetgeen t.a.v. een bloedverwant het begrijpelijkst zou wezen (Babad 115-16; zie hierna blz. 128).

\section{De drie mannen van Séla.}

Bezien wij thans het drietal, dat met kj. gedé Ngenis in verbinding heet te staan, en dat wij voor het gemak de lieden van Séla zullen noemen, aangezien het kwalijk aangaat hen thans reeds naar Mataram te betitelen, waarvan ze nog geen handbreed gronds bezitten. Hun mogelijke afstamming uit Séla blijft hierbij buiten beschouwing.

Kj. geḍe Pamanahan, Ngenis' zoon, heet naar het gebied, dat hij van de Padjangse vorst als leen zou ontvangen hebben, en dat men nu nog 
in Manahan, een westelijke wijk van Solo terugvindt. Men toont daar ook een badplaats van onze kjai geḍé, welke op initiatief van dr. ng. Poerbatjaraka voor verwaarlozing werd behoed door de bouw ener ommuring, aangebracht op last van Z.H. Mangku-Nagara VII. Deze naam en plaats wijzen er dus duidelijk op, dat hij, gelijk de traditie bevestigt, een vazal van de vorst van Padjang was. Als Pamanahan komt hij reeds vrij vroeg, n.l. in de Sadjarah Bantěn (p. 20) voor. Op een leen in Padjang wijst ook Val. IV, 72: een vrouw, een huis, en rijstvelden.

Hoe hij eigenlijk heette, wordt in de Babad niet vermeld. Slechts kennen wij uit de Sadjarah Dalem (gen. 130) een jeugdnaam: bagus Katjung, welke naam reeds bij Van der Horst (1707) voorkomt in de vorm van Castioeng. Deze traditie kan dus wel heel oud zijn.

De militaire functies van $\mathrm{kj}$. geḍé Pamanahan en zijn familielid ki Pandjarei behoeven natuurlijk weinig verbazing te wekken in een maatschappij, als de toenmalige Javaanse; de bijzondere taak, die op de schouders van kj. Djuru-Martani, hun oom rust, is reeds de gewone, welke de overlevering aan hem pleegt toe te kennen, n.l. die van wijze raadgever. Hij zal deze rol tot aan zijn dood (ongeveer in 1613) door blijven spelen.

De banden der lieden uit Séla met Padjang worden nog vaster aangeknoopt door de adoptie van kj. geḍé Pamanahan's zoon: rd. Bagus (of: Bagus Srubut), de latere Sénapati. 's Vorsten bedoeling daarmede was, om hem als landjaran te gebruiken, opdat hij zelve ook kinderen zou krijgen (Babad 48). De naam Srubut komt als Sirabut voor in Cense's Kroniek van Bandjarmasin, p. 131 en 133.

De Serat Kanḍa (443-44) noemt deze knaap: Danang, en de vorst verheft hem tot raden mas Danang, wat, gezien de Sadjarah Dalem, een verschrijving moet zijn voor rd. bagus Danar. Dit laatste kan op 's jongelings uiterlijk slaan. Het betekent n.l. fraai lichtgeel. Ook schenkt de vorst hem een gele (gouden) pajong. Zo voortreffelijk is het onderwijs, dat hij in krijgs- en staatszaken ontvangt, dat zijn eigen vader hem „Mijnen Heere” noemt.

Enige tijd later krijgt de vorst zelve ook een zoon, Rd. Penowo (ten rechte: Benawa). Ouder geworden zijnde, wordt hij tot ngabéhi verheven onder de naam van: rd. ng. Suta-Widjaja, wat wel verband houdt met 's vorsten eigen naam: Adi-Widjaja. Suta betekent n.l. zoon. Daar hij een dalem ten Noorden van de pasar bewoont, heet hij ook wel rd. ng. Sa-Lor-ing-Pasar. Volgens de Babad (51) wordt hij zelfs aanvoerder der tamtama's. 
Een historisch bezwaar tegen deze adoptie is, dat Sénapati later zo bitter weinig blijken van dankbaarheid jegens zijn pleegvader aan de dag legt, doch dit bezwaar vervalt, als men in aanmerking neemt, dat een dgl. adoptie meer het gevolg van politieke berekening kan zijn geweest, dan van onderlinge sympathie. Het geslacht van kj. geḍe Pamanahan zal een machtige stam geworden zijn, die niet slechts bezittingen had in het Padjangse, doch ook misschien daar buiten (in Séla?). Het is aannemelijk, dat de Padjangse vorst zulke invloedrijke vazallen gaarne aan zijn huis wenste te binden. En waardoor kon hij dit doel beter bereiken, dan door de oudste zoon van kj. geḍe Pamanahan als kind te adopteren? Zo hield hij deze jonge man in zijn buurt, en wellicht is daarom ook de plaats van diens dalem niet willekeurig gekozen: ten Noorden van de pasar, die aan het vorstelijk verblijf, de Kraton, grensde. Met enige goede wil kon men deze adoptie als een eerbewijs laten gelden, en de officiële geschiedschrijving suggereert deze voorstelling.

Tevens kon deze rd. ng. Suta-Widjaja als pand voor de trouw zijns vaders dienen. Vandaar wellicht de moeite, die het laatstgenoemde kostte, om zijn zoon mee naar Mataram te krijgen (S.K. 502-3).

Deze zoon van kj. geḍe Pamanahan maakt het viertal volledig. $Z \mathrm{ij}$ worden genoemd in Babad 55, 56, 59, 60 en 61, zo mede in zang VIII en XV van de Sadjarah Bantěn. In de Serat Kanḍa is hun optreden minder opvallend, b.v. op p. 478 en 489 . Toch moet deze voorstelling wel heel oud zijn. Over de bijzondere rol, die viertallen bij de Javanen speelden, vindt men een en ander in Pigeaud's Volksvertoningen (par. $360-61$ ).

Binnen die vier nemen weer twee: Pamanahan en Pandjawi, een eigen plaats in. 


\title{
DE WORSTELING TUSSEN DJIPANG EN PADJANG.
}

\author{
Padjang's eerzucht.
}

Volgens Babad Tanah Djawi (46) en Serat Kanda (437-38) beide zou „sultan Trenggana” van Demak rustig op zijn bed gestorven zijn. Het stellige bericht van de Portugees Pinto maakt dit onwaarschijnlijk. In het $179 \mathrm{e}$ hoofdstuk zijner Peregrinação deelt hij mede, dat na de moord op de vorst van Demak voor Panarukan, zulk een verwarring in het Javaanse rijk ontstond, dat de schrijver zich niet langer veilig gevoelde en dit schone eiland verliet. $\mathrm{Hij}$ duchtte, dat wel lange tijd de toestanden er niet rustig zouden worden en deze vrees was niet ijdel.

De enige Javaanse bron, waarin iets over de strijd in de Oosthoek, waarbij de Demakse vorst het leven verloor, wordt aangetroffen, is de Babad Sengkala, die voor het Javaanse jaar 1468 een oorlog met Balambangan geeft. Dit komt dus nauwkeurig met Pinto's A.D. 1546 overeen.

Voor de daarop volgende verwarring schenkt de Serat Kanda (437-38) ons nog de meeste aanwijzingen, zij het flauwe. Er wordt n.l. verhaald, dat al na Djaka-Tingkir's aankomst in Padjang, dit gebied in uitgestrektheid en volksrijkdom toenam. Ten wiens koste, wordt niet vermeld. $\mathrm{Na}$ het vernemen der ziekte van zijn schoonvader, de sultan, begeeft hij zich ijlings naar Demak. Deze belangstelling mag de kranke vorst echter niet meer baten, want hij sterft spoedig en wordt aan de Westzijde der Demakse moskee begraven.

Het verbaast ons dan te lezen, dat de Padjanger vervolgens de troon bestijgt. $\mathrm{Na}$ deze onverwachte verheffing laat hij alle pusaka-goederen uit Demak naar Padjang overbrengen, waarbij niemand hem een strobreed in de weg legt. Integendeel! Veel later, kort voor zijn huldiging door de priestervorst van Giri, beweert hij door het Demakse volk tot vorst verkoren te zijn (Serat Kanda 511).

De rechtmatige erfgenaam, pg. Ária, zoon van Trenggana, zou voor de rijkszetel bedankt hebben en geheel vrijwillig Prijaji Moekmin of een heilige Susuhunan van Prawata geworden zijn. Deze titel had toen nog slechts een geestelijke betekenis.

Prawata heet in de Babad (44) een pasanggrahan, elders een berg 
(42 en 136) of een verblijf van de Demakse sultan in de regentijd.

In ieder geval noemde de bevolking een 70 jaar geleden de bij Prawata aangetroffen overblijfselen van een ringmuur nog Kraton (Tijdschr. Aardrk. Gen. 1882 p. 82). Brumund zag er nog een bouwvallige poort, „Gapoera” genoemd, en daarachter lag een kleine hoogte, door de inwoners als de sitinggil van de kraton beschouwd. In het nabijgelegen Garoeda vond Brumund ook een badplaats, waarin heilige schildpadden rondzwommen. Dit doet sterk denken aan een dgl. vijver in Kuṭa Geḍé, waar zich ook een vermaarde schildpad bevindt.

Op twee paal van Prawata ligt de desa Oendaan, waar de kabajans nog met ontbloot bovenlijf en met de kuluk op het hoofd rondlopen, omdat zij volgens de overlevering als dienaren aan de vorst van Demak waren toegewezen.

Men ziet dus in Prawata's bouwvallen de overblijfselen van een aanzienlijk vorstenverblijf, wat stellig méér is dan de kluis van een der wereld afgestorven vorstelijke heremiet. Daarom verbaast het ons niet, dat ad. Pragola II, laatste vorst van Pați, er voor de Mataramse veroveraars een toevlucht zoekt in 1627 (Babad 136). Tot zover over dit vorstenverblijf.

De jongste zoon van de overleden vorst, pg. Timur geheten, werd vervolgens (vrijwillig?) naar Padjang overgebracht, om later over Madiun te heersen. Daar zullen we hem t.z.t. als panembahan ontmoeten.

Vervolgens verhief de Padjanger velen zijner vrienden tot hoge ambten (S.K. 439), welke handeling een succesvolle troonsbestijging pleegde te vergezellen. Zo werd aria Mantja-Nagara rijksbestuurder; Marta-Nagara en Wila-Marta tumenggungs of legerhoofden enz. De Babad noemt hem dan reeds sultan, hetgeen voorbarig is. De Serat Kandia beperkt zich tot de vorstentitel.

Al deze gewichtige staatkundige veranderingen passen wel in het door Pinto geschetste beeld der grote verwarring na de dood van de heerser over Demak, toen iedere grote naar de oppermacht streefde. Indien wij Pinto's ,pati Sudaju" heer van Sura-Baja, verblijf houdende in „Pisammanis", die door acht grote heren in Demak ten schild verheven wordt, konden vereenzelvigen met de tot vorst van Padjang opgeklommen Djaka Tingkir, zou de gelijkenis nog sprekender zijn.

Later blijkt het een der vele ergernissen van de hierna te noemen pg. aria Panangsang te zijn, dat de pangéran Prawata, welke naderhand een heilige Susuhunan wordt genoemd, het recht op zijn troon aan de Padjangse vorst zonder meer heeft afgestaan (Serat Kanḍa 447). 
De Babad (46) is over deze feiten veel droger en beknopter dan de Serat Kanda, doch ook behoedzamer. Daar wordt eenvoudig over het optreden van de Padjangse vorst het volgende gemeld:

Alle onderhorige landen onderwierpen zich. $\mathrm{Zij}$, die weerstand boden, werden verslagen. Niemand durfde zich verzetten, uit vrees voor de sekti van de adipati van Padjang. Alleen de dipati van $\mathrm{Djipang}$, pg. aria Panangsang, wilde zich niet onderwerpen.

Doch zelfs deze simpele regels doen ons het gewelddadig en heerszuchtig optreden van Padjang vermoeden, ofschoon hier van een troonsbestijging of vorstenwijding geen sprake is. Langs de ganse kust is er niemand meer, die zich tegen deze bovenlander kan verweren. Slechts de vorst van Djipang, pg. aria Panangsang durft hem trotseren.

\section{Djipang's roraakucht.}

Aan deze snodaard wordt door zijn tegenstanders een groot aantal misdaden en moorden geweten, n.l. die op Trenggana's opvolger, susuhunan Prawata en zijn echtgenote, zo mede op zijn zwager pg. KaliNjamat, terwijl men hem tevens een aanslag laat plegen op het leven van de vorst van Padjang.

De enige, die bij mijn weten, een lans voor zijn goed recht gebroken heeft, is dr. J. Brandes geweest in zijn artikel: Arya Panangsang's rechten en pogingen tot herstel daarvan (TBG XLIII 1901 488). Hij schreef dit opstel alleen op grond van gegevens, hem verstrekt door die zelfde Babad, welke over Panangsang zo slecht te spreken is.

Brandes wees er op, dat de eerste sultan van Demak, de vermaarde rd. Patah, opgevolgd werd door zijn oudste zoon pg. Sabrang Lèr. Deze „stierf weldra, terwijl hij nog geen kinderen had", meldt de Babad (39). Men placht dit overlijden in het jaar 1521 te stellen.

$\mathrm{Nu}$ had dienen op te volgen $\mathrm{pg}$. Séda-Lèpèn, de eerstvolgende zoon. Dit geschiedde echter niet, want in plaats van deze beklom zijn jongere broeder rd. Trenggana de vorstelijke zetel en verliet haar pas met zijn gewelddadige dood, vermoedelijk in 1546 voor Panarukan. Daarna werd hij opgevolgd door zijn zoon pg. Prawata.

Hierover moet zich niet slechts pg. Séda-Lèpèn gebelgd gevoeld hebben, doch ook diens zoon, pg. aria Panangsang, daar zij beiden gepasseerd waren. De wrevel van de laatste werd nog vergroot, doordat pg. Prawata, voordat hij heilig susuhunan werd, Panangsang's vader, 
pg. Séda-Lèpèn had laten vermoorden, ,toen hij van de Vrijdagse godsdienstoefening naar huis ging" door een handlanger, Sura-Jata, bode van pg. Prawata (Babad 49).

Prawata had dus niet slechts de zetel in beslag genomen, die Panangsang volgens erfrecht toekwam, doch ook diens vader laten vermoorden. Men kan zich dus voorstellen, dat hij sedertdien elk middel te baat nam, niet slechts om zich te wreken, doch ook om de macht in handen te krijgen. $\mathrm{Hij}$ poogde daarom allen, die op grond hunner afstamming van, of verbintenis met sultan Trenggana aanspraak op het bewind konden maken, uit de weg te ruimen en wel in de eerste plaats hen, die het dichtst in de buurt woonden. Dit waren dus de volgende zonen en schoonzonen van sultan Trenggana, t.w.: pg. (sunan) Prawata, die in Demak of daaromtrent gevestigd was; pg. KaliNjamat, gehuwd met een dochter van Trenggana, wonende iets verder te Kali-Njamat bij Japara; eindelijk rd. Djaka-Tingkir, eveneens met een dochter van Trenggana getrouwd, vorst van Padjang.

Inderdaad werden de aanslagen op hun leven juist in deze gegeven volgorde ondernomen. Alle slaagden, behalve de laatste (Babad 50), waardoor het spel voor pg. aria Panangsang verloren was.

Deze Babad-voorstelling bevat dus een hoge graad van innerlijke waarschijnlijkheid door zijn uitvoerigheid en vanzelfsprekendheid.

\section{Het ingrijpen der heiligen.}

De voorstelling van deze strijd is niet volledig zonder vermelding van de scherpe mededinging der beroemde leraren, welke in die tijd ,hun leerlingen onderwezen in de godsdienst van de Profeet en in de bovennatuurlijke krachten en onoverwinnelijkheid" (Babad 48). Genoemd worden de susuhunan's Kudus en Kali-Djaga. Beiden vermeldden wij reeds enige malen.

De eerste zou aanvankelijk de grootste aanhang hebben bezeten, daar als zijn leerlingen genoemd worden: pg. aria Panangsang van Djipang, sunan Prawata en de vorst van Padjang, Djaka-Tingkir.

De andere, sunan Kali-Djaga, die van buiten zou gekomen zijn (van Tjerebon?), moest zich voorlopig met mindere goden tevreden stellen, n.l. met ons drietal uit Séla. Bij hen voegde zich nog als vriend de Padjangse vorst, „op verlangen van sunan Kali-Djaga”. Dat betekende dus minder invloed voor sunan Kudus. Daarom heeft het gesprek, dat deze machtige geestelijke heer vervolgens met zijn lievelingsleerling Dg. aria Panangsang voerde, zo'n bijzondere betekenis. 
Volgens de Babad (49) zou sunan Kudus aan pg. aria Panangsang gevraagd hebben :

„Wat is de straf voor iemand, die tegelijk twee guru's heeft?" Aria Djipang antwoordde bedaard: „De doodstraf. Maar ik weet niet, wie aldus handelt." Sunan Kudus sprak: ,Je oudere broer van Prawata."

Van sunan Kudus' leerlingen hebben zich dus reeds twee bij die van zijn mededinger sunan Kali-Djaga gevoegd: Padjang en Prawata. Slechts pg. aria Panangsang is hem nog trouw gebleven. Deze spoort hij dus aan, zijn meester op de ontrouwe leerlingen, in de eerste plaats op de dichtst bij zijnde, te wreken. De Serat Kanḍa (446), schoon wat nuchterder, bevestigt deze voorstelling, al komt sunan Kudus er daar wat beter af.

Wij zullen er daarom goed aan doen, deze verhoudingen van meester tot leerlingen niet al te zeer te vergeestelijken of te veridealiseren. Stellig waren het ook politieke concentraties, deze godsdienstscholen, gelijk de wijze leraren zich heus niet tot het zuiver geestelijke beperkten, doch als echte politici in de staatszaken ingrepen. Sunan Kudus is daarom allesbehalve een der wereld afgestorven kluizenaar, evenmin als zijn collega van Adi-Langu. Prawata's overlopen kan dus zowel als een geestelijk als een politiek verraad gebrandmerkt worden.

Nevens de hierna volgende strijd tussen Padjang en Djipang zullen wij daarom ook met de wedijver tussen twee machtige geestelijke figuren of groepen dienen te rekenen, resp. gevestigd te Kudus en bij Demak (Adi-Langu). De laatste zal de zegepalm wegdragen en tot in lengte van dagen door de partij, die hij in het zadel geholpen heeft, n.l. de latere Mataramse vorsten, vereerd worden. Merkwaardig is overigens, dat deze volgens de Babad Tanah Djawi en Serat Kanḍa uit Tjerebon afkomstige heilige zich nimmer blijvend in het binnenland heeft willen vestigen, als hij er al ooit geweest is, doch bij Demak is blijven wonen, waar men dan ook zijn nakomelingen bij een keurig, te keurig onderhouden graf aantreft. $Z \mathrm{ij}$ dragen er de titel van pangéran (Sadjarah Bantěn 222). Het bestaan dezer pangérans van Adi-Langu acht dr. Pigeaud een bewijs voor de historiciteit der sunan Kali-Djagafiguur (Volksvertooningen par. 372). Het is wel merkwaardig, dat in deze strijd tussen pasisir-heiligen een hunner, sunan Kali-Djaga, de hulp van het binnenland benut. Dit zal voor de toekomst gewichtige gevolgen hebben.

Of sunan Kali-Djaga ooit in het binnenland geweest is, moet ernstig 
betwijfeld worden. Wel beschrijft de $\operatorname{Babad}(63,66)$ verscheidene bezoeken aan Midden-Java ten Zuiden, doch de oudere Serat Kanda mist deze verhalen. In zijn plaats treedt daar zijn even heilige zoon, susuhunan Adi op (S.K. 504-8).

Wellicht mogen wij hieruit besluiten, dat bij het optreden van $\mathrm{kj}$. geḍé Pamanahan de actieve rol van sunan Kali-Djaga feitelijk uitgespeeld was, zodat hij, indien hij al niet gestorven was, zich door zijn zoon liet vertegenwoordigen. Wij kunnen hem daarom misschien plaatsen omstreeks het begin en midden der 16e eeuw. Dit klopt ook met de overige overleveringen. Zo heet hij de leerling van sunan Bonang, die men omstreeks 1500 mag stellen, en doet wondertekenen bij de stichting der huidige Demakse moskee, welke men toch wel in het begin der $16 \mathrm{e}$ eeuw mag plaatsen (B.T.Dj. 22 en 31).

Het uitweiden in de Babad Tanah Djawi over sunan Kali-Djaga's lotgevallen is werkelijk zo opvallend, dat wij dit in verband brengen met het auteurschap van een of meerderen zijner nazaten.

\section{De drie moordaanslagen.}

Met de volgende moordaanslagen poogt pg. aria Panangsang zich een weg tot de oppermacht te banen (Babad 49-50) :

$\mathrm{Na}$ sunan Kudus' aanmoediging stuurde pg. aria Panangsang -een zijner harembewakers Rangkud, om sunan Prawata te vermoorden. In Prawata trof hij de vorst ziek aan, leunende tegen zijn gemalin. De sunan vroeg: „Wat ben jij voor iemand?” en onbeschaamd deelde Rangkud het doel zijner komst mede, waarop de sunan sprak: „Ga je gang, maar laat ik de enige zijn, die je doodt...." Als antwoord doorstak Rangkud met één steek zowel de vorst als zijn gemalin. Met zijn laatste krachten slingerde de stervende nog zijn kris $\mathrm{kj}$. Bețok naar de onverlaat, die licht geschramd werd (S.K.: in de voet). Bij een toverkris is dit voldoende, zodat hij neerviel en stierf. Ook sunan Prawata en zijn gemalin stierven.

De zuster van sunan Prawata, ratu Kali-Njamat, nam geen genoegen met de moord op haar broeder en, onbewust van sunan Kudus' medeplichtigheid, begaf ze zich met haar echtgenoot tot deze heilige om recht, doch verkreeg dit niet naar haar zin. Op de terugweg werden ze overvallen door boden van pg. aria Panangsang, die de vorst van Kali-Njamat doodden. „Daarop ging ze naakt als kluizenares op de berg Dana-Redja wonen. Als kleding dienden haar loshangende haren. Ratu Kali-Njamat legde de gelofte af, dat ze haar gehele leven geen kain meer zou aan- 
doen, zolang aria Panangsang nog niet dood was en...., ,wie aria Panangsang zou weten te doden, die zou ratu Kali-Njamat dienen en.... al haar bezittingen krijgen." (S.K. ontbreekt).

Daarop raadde sunan Kudus aria Panangsang aan, om de vorst van Padjang te doden, zonder dat men er iets van zou merken (S.K. : met uitgezochte krissen). Ook nu werden vier harembewakers uitgezonden naar Padjang, waar ze de vorst aantroffen, slapende onder zijn dodot. Zijn vrouwen rustten aan zijn voeteneind. Tevergeefs trachtten de harembewakers de vorst te doorsteken, maar zelfs de dodot bleek ondoordringbaar. De vier indringers vielen zelfs door het wapperen van de dodot ter aarde. De sultan, door het gegil der vrouwen ontwaakt, vergaf de aspirant-moordenaars niet alleen, doch schonk hun ook geld en kleren. Daarop vertrokken ze en brachten rapport uit bij hun heer (S.K. : elk kreeg 15 realen).

Wij wezen reeds op de logische volgorde dezer aanslagen. Wanneer vonden zij plaats? In de Babad Sengkala, die ons meer dan eens door de juistheid zijner gegevens verrast, vinden wij voor het Javaanse jaar 1471 opgegeven : ,itjalè Sang Radjeng Parwata”, hetgeen de dood van de vorst van Prawata beduidt. Dat geschiedde dus A.D. 1549. Daar wij in 1550 de vorstin van Japara zelfstandig belangrijke staatkundige handelingen zullen zien verrichten, n.l. meedoen aan een aanval op Malakka, en het ondenkbaar is, dat dit tijdens het leven van haar heer en gemaal kan hebben plaats gevonden, dienen wij dus diens dood in de jaren 1549 of 1550 te stellen. De aanslag op Padjang kan dan niet veel later geschied zijn.

Wat ook de historische waarde dezer schilderachtige verhalen ook moge wezen, zij wekken wel de indruk, dat het gezag van sunan Kudus nog zeer aanzienlijk was, daar zijn hulp als scheidsrechter door vorsten werd ingeroepen. Al weder een aanwijzing voor de grote staatkundige macht dezer heilige mannen.

Plaatselijke overleveringen omtrent de tapa, bedreven door de ratu Kali-Njamat vindt men ook in Oudheidkundige Rapporten 1910 p. $162-68$.

De bovennatuurlijke kracht, waarover de vorst van Padjang beschikt, is hier wel zeer aanzienlijk, daar zij zich zelfs aan zijn statiekleed (dodot) mededeelt. 
$\mathrm{Na}$ de mislukking van pg. aria Panangsang's aanslag op het leven van Padjangs's vorst vervolgt de Babad (51-52):

Het verslag der vier harembewakers verontrustte pg. aria Panangsang en daarom raadpleegde hij weer sunan Kudus. Hij verzocht deze de Padjanger te ontbieden ,onder voorwendsel, dat $\mathrm{U}$ met hem over de geheime wetenschappen wilt spreken. Als hij eenmaal hier is, is het gemakkelijk...."

De uitnodiging door zijn guru (S.K.: door 3 priesters) maakte Djaka-Tingkir zenuwachtig, maar hij ging toch. Op raad zijner Mataramse dienaren nam hij zijn ganse leger mee, de ruiterij voorop, het voetvolk achteraan. Aanvoerder was de patih (S.K.: eerst 400 tamtama's onder de Matarammers).

Op de alun-alun van Kudus hield de vorst van Padjang stil en sunan Kudus beval aria Panangsang hem gezelschap te houden, tot hij zelve buiten kwam. Beiden gingen tegenover elkander zitten, ieder in de rug door zijn legermacht gedekt. Aria Panangsang verzocht de kris van zijn gast te mogen beschouwen en kreeg die ook. Doch de vorst van Padjang behield nog een fraaie kris, die ook magisch krachtiger was. Zo bedreigden ze elkaar met ontblote krissen, tot sunan Kudus naar buiten kwam. Onder honende woorden staken zij hun krissen weder op en werden door de sunan naar hun pasanggrahan's teruggestuurd, welke aan weerszijden van de rivier Soré lagen (S.K.: de Padjanger ligt ten Westen van de kali Lanang).

Boven alles blijkt hier weer duidelijk de overheersende positie van sunan Kudus. Hij ontbiedt de vorsten van Djipang en Padjang, alsof het inderdaad schooljongens waren, laat hen rustig voor zijn dalem wachten, spreekt hen spottend toe en stuurt hen met een standje naar huis. De fraaie oude menara, die volgens Krom (Inleiding II, 429) hoogstens uit het begin der 16e eeuw zou dateren en zo levendig aan de Balische tromtorens herinnert, is een waardig overblijfsel uit Kudus' grote tijd ${ }^{\mathbf{1}}$ ).

Of de boven beschreven ontmoeting werkelijk heeft plaats gevonden is natuurlijk moeilijk te zeggen, doch mogelijk is het geschetste tafreel min of meer een symbolische voorstelling van een dreigend, onbeslist evenzicht tussen de beide elkander belagende grootmachten, waarbij de rivier Soré (Tjaket) of Lanang de grensrivier is. Sunan Kudus tracht tussen hen een bemiddelaarsrol te spelen.

Dit wankele evenwicht wordt plots van onverwachte zijde verstoord.

1) Over de vermoedelijke oorsprong der heren van Kudus zou men kunnen nalezen mijn verhandeling over Tomé Pires' Suma Oriental, B.K.I. 108, p. 162-63. 


\section{DJAPARA'S ROL.}

\section{De ratu Kali-Njamat.}

De Babad (52-54) brengt de vorstin van Djapara ten tonele:

$\mathrm{Na}$ de wonderlijke ontmoeting met pg. aria Panangsang besprak de vorst van Padjang zijn moeilijkheden met zijn ondergeschikten uit Séla, die hem rieden, de ratu Kali-Njamat te bezoeken. Aldus geschiedde. De vorst gaf haar in overweging haar askese te staken, doch zij wilde aan haar gelofte vast houden en beloofde hem, als hij Panangsang doodde, de rijken Kali-Njamat (Djapara) en Prawata (Demak), benevens al haar schatten. De Padjanger verklaarde zich niet bereid, om tegen de machtige uit Djipang ten strijde te trekken, maar besloot toch, op fluisterend aanraden van ki Pamanahan, de zaak nog één dag in beraad te houden.

Naar twee zijden bereidde daarna ki Pamanahan de strijd voor. De vorstin ried hij bij haar aanbod nog een paar knappe vrouwen te voegen, aangezien de vorst daar een zwak voor had. Deze vergemakkelijkte hij de kamp, door hem voor te spiegelen, hoe de strijd even goed door een vrijwilliger kon worden uitgevochten, mits men hem een beloning in het vooruitzicht stelde.

Zo gebeurde het ook. De Padjangse vorst deed bij zijn tweede bezoek aan de berg Dana-Redja het voorkomen, of hij de heldendaad zelve zou verrichten en kreeg tot loon de beide schone vrouwen al vast mee. Weliswaar behoorde dit tweetal aan een hevig jaloerse kadjineman, wiens toestemming niet gevraagd was, doch diens aanslag mislukte.

In de Serat Kanḍa (466-68) wordt de zaak veel eenvoudiger voorgesteld. Het enige bezoek van de Padjangse vorst aan Djapara valt daar reeds vóór het befaamde onderhoud in Kudus. Van enige inmenging van kj. gedé Pamanahan c.s. is geen sprake, zodat de vorst in een gunstiger licht komt te staan. Door de smart der ratu geroerd, belooft hij dadelijk zijn gulle medewerking. De berg Dana-Redja heet er: Setoto. Bezien wij thans eerst de heldin van het verhaal.

Deze vorstin van Djapara is feitelijk de enige Javaanse figuur uit de $16 \mathrm{e}$ eeuw, die, dank zij de Portugese berichten, enigszins belijnd voor ons staat. In het buitenland heet zij naar de grote haven van haar rijk Djapara; bij de Javanen naar haar hofstad Kali-Njamat. De berg DanaRedja ligt aan de Noordzijde van de rivier van Djapara, terwijl de kota 
aan de Zuidkant ligt. Dat Djapara en Kali-Njamat bijeen horen blijkt uit de mededeling van de Portugees Diego de Couto in zijn Da Asia (dec. IV, libr. III cap. 1), waar hij onder de rijken van Java ook Japará vermeldt, „cuja cidade principal se chama Gerinhamá” (welks hoofdstad Kali-Njamat heet).

Elders (IX, xvir) noemt De Couto de vorstin „Rainha de Japara, senhora poderosa e rica" (koningin van Djapara, een rijke en machtige vrouwe). Gelijk wij zien zullen, was zij zeer belust op het vernietigen der Portugese macht in Malakka, tegen welke zij tot twee maal toe, volgens de Portugese berichten, het zwaard trok. Ook verschaffen de Portugezen ons twee jaartallen, die binnen het bewind der ratu KaliNjamat als zelfstandig vorstin hebben gelegen: vóór 1550 moet zij weduwe geworden zijn en ná 1574 overleden, doch vóór 1593, want toen regeerde er al weer een koning over Djapara.

Een opmerkelijke overeenstemming tussen de Portugese en Javaanse berichten heerst t.o.v. de rijkdom der vorstin. Terwijl de Portugezen haar „rica” noemen, schonk zij volgens de Babad (62) en Serat Kanḍa (487-98) twee gouden ringen weg, getooid met een robijn en een diamant. Volgens de laatste bron voegde zij er nog een groot deel der rijkdommen van Kali-Njamat aan toe. Deze schat werd aan de opbouw in Mataram besteed (p. 500).

Bezien wij thans eerst de ons best bekende krijgsverrichtingen der koningin, n.l. haar aanvallen op Malakka in 1550 en 1574, gelijk die ons door De Couto in zijn Da Asia bericht worden.

\section{Djapara's aanvallen op Malakka.}

Twee malen werd de vorstin van $\mathrm{Djapara}$ aangezocht om mee te doen aan een aanval op het Portugese Malakka en beide keren ging $z \mathrm{ij}$ in op de uitnodiging.

In 1550 schreef de vorst van Djohor een brief, waarin hij haar tot de heilige oorlog tegen de Portugezen aanmoedigde (De Couto VI, IX). Dezen zouden n.l. niet op hun hoede zijn en aan allerlei gebrek lijden. De vorstin beantwoordde deze oproep met het zenden van een machtige vloot. Van de 200 schepen der Moslimse bondgenoten kwamen er alleen al 40 uit Djapara, bemand met 4 tot 5000 krijgslieden. De aanvoerder der Javanen, Sang Adipati genaamd, zou een zeer dapper man geweest zijn. Inderdaad hadden de Javanen een belangrijk aandeel in de belegering der stad. $\mathrm{Zij}$ vielen deze van het Noorden aan en maakten zich daar van de wijk der Inheemsen meester. 
Toen de Maleise bondgenoten, beducht voor een aanval der Portugese vloot op hun steden en havens, het beleg opbraken, hielden de Javanen toch vol. Maar zodra de Portugezen een hevige uitval deden, weken zij. Een der Javaanse groten werd daarbij gedood en zijn ,espada e hum cris guarnacido de ouro" (degen en een kris, versierd met goud) vielen in handen der Christenen. Toen zij hun leider zagen vallen, vloden de Javanen in verwarring naar het strand en trachtten zich overhaast in te schepen, waarbij de strijd te land te water werd voortgezet. Meer dan 2000 Javanen sneuvelden en hun ganse bagage ging verloren: ,artilleria, muniçôes, mantimentos e mais cosas" (geschut, kruit, voedsel enz.). Hun kampement werd in brand gestoken. Door een juist opstekende storm liepen nog twee volgeladen Javaanse jonken op de kust en werden een prooi der Portugezen. Ook richtten enige zee kiezende Portugese vaartuigen aanzienlijke schade aan. Het einde was, dat minder dan de helft aan uitgevaren schepen en manschappen Djapara zou hebben weergezien.

Doch niettegenstaande deze nederlaag bleef de vorstin van $D j a p a r a$ machtig en ondernemend.

In 1573 werd zij n.l. opnieuw voor een tocht tegen Malakka aangezocht, ditmaal door „o Achim tyranno, insolente e poderoso” (de tyran van Atjeh, onbeschaamd en machtig). Ofschoon zij begerig was, om opnieuw met de Portugezen de wapens te kruisen, verscheen haar vloot niet dadelijk op het appèl, wat de Portugezen als een genadige bijstand des Hemels beschouwden. Indien n.l. de Maleiers tegelijk mèt de Javanen verschenen waren, zou Malakka zijn ondergang niet hebben kunnen ontgaan. (De Couto IX, xvir).

De vloot van Djapara kwam pas in October 1574 voor Malakka (De Couto IX, XIX). Zij telde ditmaal wel 300 zeilen, w.o. 80 grote djungs (jonken), elk van ongeveer 400 ton. De bemanning bestond uit 15.000 uitgezochte Javanen. Voorts waren er massa's voorraden, geschut en kruit aan boord. De aanvoerder, „Regedor principal de seu Reyno” (voornaamste bestuurder van haar rijk) heet "Quilidamâo", mogelijk een verbastering van kjai demang (Laksamana?). De vloot begon met een geschutsalvo, dat de indruk wekte, alsof de aarde ineenstortte. De volgende dag landde de Javaanse generaal zijn troepen en liet loopgraven aanleggen. Een uitval der Portugezen op hun stellingen ontmoedigde de Javanen ten zeerste. Bij een aanval op hun vloot gingen 30 hunner djungs in vlammen op. $Z$ ij beperkten zich nu tot een blokkade ter zee, door het aanbrengen van een staketsel met hoge blokhuizen in het water. 
Pas na een herhaalde aanval gelukte het de Portugezen, deze ring met moeite te doorbreken. Daarop waren de Javanen tot onderhandelen bereid, waartoe niet hun generaal, doch een geestelijke "Dato" (datu?) genaamd, zich leende. De eisen der Portugezen waren echter te zwaar en werden afgewezen. De onderhandelingen gingen toch door. Pas het wegnemen door de Portugezen van een zestal hunner vaartuigen met voedsel, hun uit Djapara toegezonden, bewoog de Javanen, die langzamerhand van belegeraars belegerden waren geworden, tot een plotselinge en overhaaste aftocht, waarbij de Portugezen hun nog de nodige verliezen toebrachten. Hierbij was ook de vrees voor een terugkeer der Atjehers, met welke de Javanen slecht overweg konden, een factor van betekenis. Alleen rondom Malakka vond men een 7000 graven van Javanen, doch het gehele verlies werd op $2 / 3$ der uitgevaren macht geschat. Het beleg had drie maanden geduurd.

Zo was deze vorstin van Djapara tot 1574 behalve rijk, ook nog zeer machtig. Men zal er goed aan doen, haar belangstelling voor Malakka te zien in verband met de economische banden tussen deze koopstad en Djapara. Laatstgenoemde plaats was nl. de grote uitvoerhaven voor rijst, welke Malakka in sterke mate behoefde.

Tochten van Djapara uit naar Bantam en de Molukken.

Doch wij dienen nog een tocht in dit kader te vermelden, n.l. de vergeefse expeditie tegen Bantam in 1580, waarvan wij helaas niet zeker weten, of wij die aan haar initiatief nog moeten toeschrijven. In ieder geval bewijst deze zeetocht naar West-Java, dat Djapara zich nog in zeker opzicht beschouwde als de voortzetter der tradities van Demak.

Volgens de Sadjarah Bantěn (p. 34) zou de jongste zoon van Bantam's eerste wereldlijke vorst, Hasanudin, pangéran Arja genaamd door de sultan van Demak zijn opgevraagd en toevertrouwd aan diens dochter, ratu Djapara, reden waarom hij $p g$. Djapara genoemd werd.

Deze sultan moet Trenggana geweest zijn, die in 1546 stierf. Daar de genoemde pg. Djapara een zoon van zijn dochter was, die met Hasanudin gehuwd was, maakte Trenggana bij het opeisen van dit kind gebruik van zijn recht als grootvader. Deze opeising diende blijkbaar, om Bantam nauwer aan het Demakse huis te binden.

Aan de tocht van Hasanudin tegen het heidense Pakuan nam deze pg. Djapara dan ook geen deel (Sadj. Bant. 35), immers, hij was uitstedig. Doch wel verscheen hij, toen Bantam's tweede vorst, Molana Jusup in 1580 op sterven lag (Sadj. Bant. 37). Hij kwam niet alleen; 
een groot gewapend gevolg omstuwde hem, onder welke men niemand minder dan de door de Portugezen vermoedelijk reeds vermelde $k j$. demang Laksamana opmerkte. Deze voornaamste bestuurder van het rijk zal de overzeese reis naar Bantam zeker niet zonder voorweten van zijn vorst of vorstin ondernomen hebben.

Toen nu Molana Jusup de laatste adem had uitgeblazen, poogde pg. Djapara met stille medewerking van de Bantamse rijksbestuurder zijn neef, pg. Muhammad, die pas 9 jaren telde, de troon afhandig te maken. Bijna was hij geslaagd toen deze verraderlijke patih, na ontvangst van een schriftelijke wenk van een der voogden van de jeugdige vorst, berouw kreeg over zijn daad en op zijn beurt pg. Djapara verried. Daarop ontbrandde in Bantam een hevige strijd; ki demang Laksamana sneuvelde en pg. Djapara moest onverrichterzake naar zijn stad terug (Sadj. Bant. 37-39).

Ging deze vergeefse tocht nog van de vorstin van Djapara uit? Haar naam ontbreekt in het bovenstaande relaas, doch bij deze soort van bronnen legt het argumentum e silentio zelden veel gewicht in de schaal.

Het is echter zeer goed mogelijk, dat zij tussen 1574 en 1580 was overleden.

Heeft zij zich ook nog voor de Molukken geïnteresseerd? In de kroniek van „den Moorschen Priester" Ridjali, waarvan Valentijn, die hem in bezit gehad heeft, een uitvoerig uittreksel geeft (II, Ambonsche Zaaken 1 en vlg.) wordt herhaaldelijk over politieke verbindingen tussen Djapara en Amboina gesproken; er worden zelfs namen en titels genoemd, doch het grootste bezwaar is het ontbreken ener behoorlijke chronologie, hetgeen reeds Valentijn opmerkte (ibidem p.7: „zonder eenige aanwijzing van den netten tijd").

Een Perdana Djamiloe, ,gemeenlijk de Capitein van Hitoe” genaamd, zou, wschl. na 1510, een gezant naar Djapara hebben gezonden ,aan dien Pangirang of Prins.... een verbond met hem gemaakt, en van den zelven den Titel van Patinggi.... verkregen” hebben. „Deze vriendschap, met over en weer gezanten te zenden, duurde zo lang deze Pangeran Njaykabawang leefde, na wiens dood die ophield, alzo de volgende Pangirang zo opregt niet was...."

De enige pangéran van Demak (Demak stellen wij hier voor zijn grootste haven Djapara), wiens plotselinge dood een ommekeer in het rijk veroorzaakte, is de ten onrechte als sultan bekende pg. Trenggana. $\mathrm{Na}$ zijn vermoording in 1546 zullen de banden met de Molukken losser geworden zijn. De naam Njaykabawang is niet terug te vinden. 
Op blz. 7 zal dezelfde Pangirang van Japara bedoeld zijn, tot wie Perdana Djamiloe zich wederom om hulp wendt. Hij krijgt 7 oorlogsfusten mee, doch ofschoon Perdana Djamiloe tussen Java en Bali komt te overlijden, bewijst de Javaanse vloot toch goede diensten: de bemachtiging van een Portugees schip onder Banda, de verovering van het heidense Hative (p. 8).

Ook de tocht van een ander Hitoes hoofd, Perdana Toeban Besi naar de Pangerang van Japara, die ditmaal ,kijay Maas” heet, moet wel onder Demak gevallen zijn. Diens „dappere zeevoogd” draagt de Javaans klinkende naam van Marta-Djoeta en op zijn „schoone Vloot” bevinden zich enige grote lieden van Panaroekan en Passoeroean. De aanwezigheid dezer laatsten maakt het waarschijnlijk, dat deze tocht nog tijdens het rijk van Demak ondernomen werd, aangezien een gemeenschappelijk bewind over Djapara en de Oosthoek na 1546 onwaarschijnlijk is. Bovendien vermeldt Pinto de koning van Panarukan (waarvoor wschl. Pasuruhan dient gelezen te worden), als admiraal der Demakse vloot.

Daarentegen valt de ,gezant van een Pangirang van Java”, die enige tijd een vesting tegen die der Portugezen maakte (p. 10) samen met de expeditie van de Radja Giri (of Radja Boekit) in 1565-68.

Het is dus niet aan te nemen, dat de vorstin van Japara ooit een expeditie tegen de Portugezen naar de Molukken heeft gezonden. Veel meer voor de hand ligt, dat zij zich met de Westelijke helft van de Archipel bezig hield, terwijl zij het Oosten aan de plaatsen bij SuraBaja, zoals Giri, overliet.

\section{Djapara en het binnenland.}

Heeft zij zich ernstig met de binnenlandse zaken van Java ingelaten? Vast staat wel, dat zij zich door pg. aria Panangsang's moord op haar broeder en echtgenoot diep gegriefd voelde en de daarop volgende merkwaardige tapa toont wel aan, dat zij er niet in wilde berusten. Doch zij steunt de wrekers dezer moorden niet met een krijgsmacht, maar met haar schatten en bezit, zegt de overlevering. De zeestad Djapara voelde zich te land niet thuis. Daarom maakt de vorstin in de bovenlandse overlevering, niettegenstaande haar bittere haat, toch zo'n lijdelijke indruk.

Het aandeel in Panangsang's nederlaag van de Matarammers of lieden van Séla is vermoedelijk niet aanzienlijk geweest. Het heeft er 
inderdaad veel van, alsof een oorspronkelijk Padjangs verhaal naderhand in Mataramse zin is omgewerkt, zodat wij bij alle belangrijke zaken, die de vorst van Padjang verricht, tevens kj. geḍe Pamanahan of een zijner verwanten zien assisteren. Het gevolg is, dat de landsheer er zelfs niet al te best afkomt, allerminst in de Babad.

Zo waarschuwen zij hun vorst tegen de verdachte uitnodiging van sunan Kudus; zij rukken met hem op aan het hoofd der troepen (51); dekken hem tijdens het befaamde onderhoud met pg. aria Panangsang (52); raden hem 's avonds bij de ratu van Kali-Njamat op bezoek te gaan. Zij begeleiden hem daarheen en ki Pamanahan fluistert zijn meester goede raad in (53). Ten slotte organiseren zij zelfs de prijskamp tegen de Djipanger door hun onderhoud met de ratu en de vorst (54). Dit is inderdaad ietwat te veel van het goede.

Van dit alles bezit de Serat Kanḍa dan ook weinig of niets. De rol der lieden van Séla zal vrij bescheiden geweest zijn. 


\title{
DE BESLISSENDE STRIJD.
}

\author{
De overwinning op Djipang.
}

Vele bladzijden wijdt de Babad (55-60) aan de grote strijd tegen pg. aria Panangsang van Djipang:

Wel loofde de vorst van Padjang de rijken Pați en Mataram uit voor de overwinnaar in de strijd tegen Panangsang, doch niemand durfde. Een tweede oproep, zelfs tot grassnijders gericht, volgde daarop.

Ten huize van $\mathrm{kj}$. geḍé Pamanahan bespraken thans de vier Matarammers deze oproep. Op raad van $\mathrm{kj}$. Djuru-Martani, die een listige uitdaging voorstelde, ondernamen $\mathrm{kj}$. geḍé Pamanahan en ki Pandjawi het, zich aan te bieden. Zonder andere hulp dan die zijner eigen verwanten beloofde kj. geḍé Pamanahan de strijd te voeren (55). Daarop rukte hun leger op naar de Tjaket, 200 man sterk.

Zij vingen daar een grassnijder van Panangsang, die voor diens paard Gagak-Rimang gras sneed. Tegen 15 realen vergoeding sneed men hem het ene oor af, terwijl aan het andere een honende uitdagingsbrief werd gebonden. Zo keerde de stumper terug. Djipang's rijksbestuurder, ki Mataun, ontstelde hevig bij dit gezicht en poogde te vergeefs de indruk voor zijn driftige heer te verzachten (57).

De.komst van de mishandelde grassnijder met zijn beledigende brief wekte inderdaad een driftbui op bij pg. aria Panangsang, die net aan de rijsttafel zat en wiens met rijst gevulde hand een bord aan stukken sloeg. Zijn broeder, aria Mataram, trachtte nog zijn toorn te bezweren, doch reeds rende Panangsang te paard weg, de rijzweep hanterende, terwijl de asthmatische ki Mataun hem hijgend volgde, zonder hem in te halen (58).

$\mathrm{Na}$ spottende en uitdagende woorden stak de Djipanger de rivier over, waarop de volgende vloek rustte: hij, die de rivier oversteekt, zal de strijd verliezen. Een verbitterde kamp volgde en honende daagde pg. aria Panangsang „Karèbèt” uit, ofschoon hij zwaar in het onderlijf gewond werd.

Toen bond kj. gedé Pamanahan's zoon de strijd aan, gewapend met de lans kj. Plèrèd, terwijl de twee ouderen hem bewaakten en kj. Djuru-Martani listig een merrie losliet. Daardoor werd de hengst van pg. aria Panangsang dartel, doch ook het veulen met de kortgeknipte manen van de jetugdige held rende met zijn meester weg, die er bijna was afgevallen (59). Sedert mocht geen zijner 
nazaten meer zo'n beest ten oorlog berijden (deze taboe-historie ontbreekt in de Serat Kanda).

Daarna streed de jongeling te voet en doodde pg. aria Panangsang met de heilige speer, waarvan een stukje afbrak. Het lijk werd door de lieden van Séla afgelegd. Ki Mataun, die te laat kwam, werd door allen aangevallen en gedood. Zijn hoofd werd op een staak gestoken aan de kant van de rivier. Het aanrukkende Djipangse leger onderwierp zich (50).

De Serat Kanḍa (475-85) is weer veel eenvoudiger. Na het opbreken der vergadering bij sunan Kudus, trekt pg. aria Panangsang dadelijk weg, doch de vorst van Padjang blijft nog wat in zijn tent vertoeven ter raadpleging, ver van Kudus. Dan looft de vorst Mataram en Pați uit, maar niemand durft dan kj. Pamanahan en Pandjawi. Daarop trekt de vorst van Padjang nog meer terug, gevolgd door pg. aria Panangsang. Eindelijk houden ze stil aan weerszijden van de rivier de Sore. Die nacht bewaakt het volk hun vorst tegen een onverwachte aanval van Panangsang. (475-76).

De volgende morgen kondigen de drie lieden van Séla hun aanval op pg. aria Panangsang aan. De vorst moet maar in zijn pondok blijven. Slechts verzoeken zij zijn aangenomen zoon. Daarna rukken de vier lieden van Séla op met 300 dapperen uit die plaats, en nog wat Padjangs volk. $\mathrm{Zij}$ binden hun wapens tot bossen om niet op krijgslieden, doch op kooplui te gelijken (477-79).

$Z$ ij laten dan hun volk aan de Westkant van de Soré stil houden en zelve pikken zij aan de overzijde een stalknecht op, wie zij sneden aan beide oren geven. Aan één oor hangen zij een uitdagende brief, terwij1 zij hem 15 realen smartegeld geven, waarmede hij zeer tevreden is $(480-81)$.

Het vervolg (482-84) is dan als in de Babad. Aria Mataram wordt niet met name genoemd, doch omschreven als een broeder, ,gesprooten uijt een onegte bed". Panangsang beledigt hem zwaar! (485).

Het gevecht heeft evenmin sterke afwijkingen. De jongste der vier van Séla wondt aria Panangsang met de lans kj. Plèrèd diep in de rechterzijde, terwijl deze het zwarte paard van zijn tegenstander wondt. Doordat de hengst van de Djipanger wild wordt bij het zien van de door kj. Djuru-Martani losgelaten merrie, opent zich zijn wond, puilen de ingewanden er uit, wat zijn dood ten gevolge heeft, niettegenstaande zijn bravoure.

De voorstelling is, dat pg. aria Panangsang vèr voor de Padjangse linies in een hinderlaag valt, hem door de vier van Séla gespannen. Hun 
vermomming als kooplieden lijkt een onhandige poging van de schrijver der Serat Kanḍa om het karakter van een listige overval te doen uitkomen. Aldus valt alle glorie der zege aan die van Séla ten deel. Of dit het enige militaire feit in deze oorlog geweest is, die ongetwijfeld jaren lang geduurd heeft, moet betwijfeld worden.

Het karakter van pg. aria Panangsang, zoals het hier geschilderd wordt, doet wel sterk aan dat van een buta of reus denken. Duidelijk is het streven, om hem enigszins belachelijk voor te stellen. Men denke aan de fijngeknepen bal rijst!

In de geschiedenis van het gevecht aan de rivier zijn ongetwijfeld verschillende overleveringen verenigd. Vooreerst de ernstige buikwond van pg. aria Panangsang, met zijn daarop volgende overmoed en grootspraak. Dan de list van $\mathrm{kj}$. Djuru-Martani met de losgelaten merrie. Vervolgens het optreden van de jonge prins met de toverlans $\mathrm{kj}$. Plèred. Ten slotte, alleen in de Babad, het onhandelbaar worden van 's prinsen rijdier met de voor zijn nakomelingen bindende gelofte.

Niet slechts dat deze laatste episode er los bijhangt, het ganse verhaal van de heldendaad van de jonge Suta-Widjaja ziet er vreemd uit. Kennelijk wilde men de stichter der Mataramse grootheid nog een extra pluim op de hoed zetten en door deze zege aanspraken verlenen op het ganse gebied van Mataram én Pați. Dit was van belang, omdat later tussen beide takken van hetzelfde stamhuis een bloedige strijd is ontbrand. Kon men dus aantonen, dat Suta-Widjaja door zijn overwinning op pg. aria Panangsan óók aanspraken had op het Noordelijke Pati, dan versterkte men zijn positie in de eerste Pati-se oorlog (1600), waarin Pandjawi's zoon Pragola I het leven verloor, en tevens die van sultan Agung, welke Pragola II verslagen en gedood, en diens bezit bij het zijne had gevoegd (1627).

Dat Pați oorspronkelijk niet aan de Zuidelijke tak, doch aan de Noordelijke was toegekend, was blijkbaar zulk een sterke overlevering, dat zij niet te loochenen of te negeren viel. $Z$ ij kon daarom alleen krachteloos gemaakt worden door de opneming van een nieuw verhaal, dat aan de latere Sénapati de hele eer der overwinning toewees. Deze nieuwe geschiedenis is dus een indirect bewijs voor de kracht der oude overlevering. Op deze toekenning van Mataram en Pați komen wij terug.

Wat enige eigennamen betreft, de naam van Panangsang's paard Gagak-Rimang, verliefde kraai, lijkt niet kwaad gekozen.

De naam van de rijksbestuurder: Mataun, komt reeds in de Nagarakrtagama voor, waar wij een vorst van Matahun aantreffen, terwijl later 
over Djipang regenten heersen, die Mataun heten (Babad 344). Het moet dus wel een daar inheemse naam zijn, zoals wij er wel meer bij regentengeslachten aantreffen.

Tot zover onze poging tot verklaring en waardering der Javaanse berichten. Wij beschikken echter nog over een vrij oud Nederlands bericht, dat het feit van de strijd Padjang en Bodjo-Nagara zeer waarschijnlijk maakt, hetwelk wij thans zullen behandelen.

\section{Nederlandse berichten omtrent de strijd Padjang-Panangsang.}

Over de mogelijkheid, dat J. Pz. Coen reeds iets over Mataram en Padjang vernomen had, spraken wij reeds (blz. 13).

Het eveneens reeds besproken bericht van de hoveling Djaga-Pati aan Speelman van 16 Maart 1677 is wel veel jonger, doch tevens veel uitvoeriger. Het bevat n.l. één bijzonderheid, die wij in de Javaanse overleveringen missen, doch welke er zeer betrouwbaar uitziet. (K.A. 1218 f. 1834r).

Djagi-Pati verhaalt dan over kj. geḍé Mataram, een ,aensienlijck hoof- en camerdienaer.... van Sultan Padjang.... En door gonst van sijn heer tot staet gebracht sijnde", zou deze vorst na een oorlog tegen de stad "Soude omtrent Demack, hem de stadt Mataram, die doe noch maer cleen was, vereert" hebben.

Dit is dus, zij het beknopt, de voorstelling der traditie, doch met vermelding van de plaats, tegen welke gestreden werd: Soude. Onder de 26.000 plaatsnamen, voorkomende in het Alphabetisch register van.... W. F. Schoel, komen er slechts twee, dicht bij elkaar liggende desa's ter gelijkstelling met dit Soude in aanmerking, n.l. "Soedah" en "Soedoe", beide aan de Solo-rivier, een $30 \mathrm{~km}$ ten Westen van BodjoNagara of Djipang. Het komt mij waarschijnlijk voor, dat om deze plaats of plaatsen, die een bolwerk ter verdediging van aria Panangsang's residentie zouden kunnen vormen, bitter gestreden is. Bovendien leent zich een bocht in de rivier aldaar uitstekend ter afweer van een uit het Westen naderende vijand. Een ander historisch aanknopingspunt is misschien de ten Noorden van Soedah gelegen heuvel, die Kadaton heet. De Tjaket of Soré dient dan de Solo-rivier te wezen.

Een bezwaar tegen de gelijkstelling Soude-Soedah-Soedoe is de toevoeging, dat Soude bij Demak zou liggen. Is dit een geografische fout of een vergissing van een afschrijver?

Zònder deze moeilijkheid zouden wij dus een vrij stellige aanwijzing hebben van de strijd tussen Padjang en Djipang. 
Het tijdstip van pg. aria Panangsang's ondergang is slechts te gissen. In de Babad Sengkala A.J. 1480 (A.D. 1558) is er sprake van de dood van een „tjaraka” (= bode). Met enige goede wil zou hierin de mishandelde grassnijder te herkennen zijn, die met een uitdaging tot pg. aria Panangsang werd gezonden. Zou een andere overlevering soms zijn dood door de driftige Djipanger vermelden? Dan zou ook diens ondergang in dat zelfde jaar 1558 hebben plaats gevonden.

$\mathrm{Zijn}$ slachtoffer pg. Kali-Njamat is ter aarde besteld bij de moskee van Mantingan. Het fraaie beeldhouwwerk van de moskee en de bijbehorende grafkapel vond een waardige bespreking en afbeelding in het Jaarverslag van de Oudheidkundige Dienst 1930.

Hierin vindt men een sengkalan vermeld, waarvan de inhoud A.D. 1559 is. Dit ligt wel merkwaardig dicht bij het veronderstelde doodsjaar van pg. aria Panangsang: 1558 en kan niet zonder betekenis zijn.

Immers, de ratu Kali-Njamat zal er niet aan hebben kunnen denken, zulk een weids praalgraf voor haar vermoorde echtgenoot (en later ook voor zich zelve) op te richten, eer diens machtige en invloedrijke moordenaar van het toneel verdwenen was.

Het jaar na diens sneuvelen werd dus de moskee bij het graf van zijn slachtoffer voltooid. Ofschoon er met deze bouwwerken in de loop der eeuwen nog al zwaar geknoeid is, kunnen wij er nog het meesterlijke beeldhouwwerk bewonderen, dat soms de fijnheid van Japara's houtsnijwerk benadert. Raden Adjeng Kartini schreef over deze graven in haar brief van 2 Sept. 1902. 


\title{
DE BELONING DER LIEDEN VAN SELA.
}

\author{
Toekenning van Pați en Mataram.
}

De overwinning op pg. aria Panangsang had zekere staatkundige gevolgen, welke door de Babad (61-65) als volgt worden beschreven:

$\mathrm{Na}$ de zege besloten de lieden van Séla, op raad van $\mathrm{kj}$. DjuruMartani, niet te zeggen, dat rd. ng. Suta-Widjaja de Djipanger neergeveld had, doch $\mathrm{kj}$. Pamanahan en Pandjawi, opdat eerstgenoemde, feitelijk nog een kind en de zoon van de vorst, niet met mooie kleren zou worden afgescheept. Dit werd nu algemeen bekendgemaakt.

De volgende dag, op openbaar gehoor, leverde men de onderworpen Djipanger uit en vertelde, wie de overwinnaars waren. Daarop informeerde de vorst naar de lotgevallen van aria Mataram, die met onbekende bestemming vertrokken was (61).

Vervolgens liet hij $\mathrm{kj}$. geḍe Pamanahan de keuze tussen Paṭi en Mataram. Deze vond in zijn eerstgeboorterecht slechts aanleiding om de minste te wezen. „Ik kies dus, wat nog bos is,” verklaarde hij, ,laat broer Pandjawi Pati maar krijgen, wat reeds een stad is met veel inwoners, en ik Mataram, dat nog een wildernis is."

Dus mocht Pandjawi dadelijk naar Paṭi gaan, dat hij goed moest beheren. Pamanahan werd naar Japara gezonden, om de ratu Kali-Njamat van de uitslag van de strijd op de hoogte te stellen. Daarna pas zou hij Mataram krijgen.

Aldus geschiedde. Pamanahan weigerde alle geschenken van de verheugde ratu, t.w. de rijken Prawata en Kali-Njamat, zelfs alle kostbaarheden, doch niet de pusaka's. Zo ontving hij 2 ringen: Mendjangan-Bang (met een robijn) en Uluk (met een diamant), doch hij moest ze goed verstoppen! Ook kreeg hij alle vrouwen mede van wijlen pg. Kali-Njamat (62).

Terugkerende deed Pamanahan nog Séla aan, vanwaar hij 150 familieleden medenam, die van hem hielden, om met hem in Mataram te wonen.

Van de aangeboden vrouwen behield de vorst er slechts één, die hij nog aan Pamanahan in bewaring gaf, tot ze huwbaar zou zijn. De overgave van Mataram werd echter opnieuw uitgesteld.

Pamanahan, daardoor beschaamd, ging naar Kembang-Lampir, waar hij tapa bedreef. Daar bezocht hem sunan Kali-Djaga (63). Deze heilige raadde de reden zijner uitwijking en bracht hem op 
bovennatuurlijke wijze in eens voor de vorst. Deze werd ter verantwoording geroepen, doch poogde er zich met een smoesje van af te maken. Hij wilde een nòg mooier gebied voor Pamanahan uitzoeken! Inderdaad hinderde hem een voorspelling van sunan Giri, dat er mettertijd in Mataram iemand als vorst zou opstaan, die even groot zou zijn als hij (64).

Pamanahan legde daarop op een dubbelzinnige gelofte af, waarmede allen genoegen namen.

De Serat Kanḍa (494-504) is over dit onderwerp veel eenvoudiger. Ook hier besluiten $\mathrm{kj}$. geḍé Pamanahan en ki Pandjawi zich zelve de eer der zege toe te kennen, om dusdoende Pați en Mataram te verkrijgen. Daarop worden beiden naar de berg Dana-Redja gezonden om de vorstin de overwinning te melden. Deze schenkt nu Mendjangan Bang aan kj. geḍé Pamanahan, en bestemt voor haar zwager Uluk, zo mede een zeer jonge, schone maagd van goede familie, welke voorlopig aan Pamanahan wordt toevertrouwd.

Vervolgens ontvangen de beide helden ieder hun aandeel, doch een deel van de schat van Kali-Njamat wordt voor de opbouw van Mataram bestemd, waar een regentschap moet komen.

Ten slotte verzoekt kj. geḍé Pamanahan zijn zoon rd. ng. SutaWidjaja als hulp, hetgeen na een zéér lange aarzeling wordt goedgevonden, mits hij regelmatig ten hove verschijnt. Tot bewijs zijner aanstelling ontvangt hij een piagem (acte).

De aarzeling om Mataram af te geven en de interventie van sunan Kali-Djaga ontbreken dus in de Serat Kanḍa, die als gewoonlijk, nog al sober is over deze heilige.

Alvorens andere berichten over deze gebeurtenissen naast het bovenstaande te leggen, onderzoeken wij de Mataramse traditie op haar innerlijke waarde.

Vooreerst klinkt het uitloven van twee zo gewichtige gebieden als Pați en Mataram voor één heldenfeit meer sprookjesachtig dan historisch. Ernstiger redenen dan dankbaarheid moeten de vorst van Padjang bewogen hebben, om deze landen aan de lieden van Séla te laten.

Ten tweede is de verdeling zelve wel heel wonderlijk, om niet te zeggen onbillijk. Terwijl volgens de overlevering kj. geḍé Pamanahan een veel gewichtiger aandeel in de overwinning heeft gehad dan ki Pandjawi, is het toch de laatste, die met het leeuwendeel gaat strijken. De Babad zelve geeft het toe! Pați telt 10.000 inwoners, een voor die tijd aanzienlijk getal - het is de enige maal, dat in de Babad het 
inwonertal van een plaats wordt vermeld - terwijl Mataram niets anders bezit dan een roemrijke naam, stammende uit een verleden, waaromtrent men alles vergeten was. Sedert heet ook ki Pandjawi: kj. ageng Pați en gaat echt van zijn rijkdom en weelde genieten, terwijl kj. gedé Pamanahan thans wel naar Mataram gezonden wordt, doch mag beginnen met er bomen te rooien.

Natuurlijk vermag de Babad dit vreemde verschijnsel te verklaren. Zij schrijft kj. gedé Pamanahan's gering aandeel toe aan 's mans overgrote bescheidenheid op het ogenblik der beslissende keuze. „Omdat ik de oudste ben, is het niet meer dan behoorlijk, dat ik de minste wil zijn", zo verklaart hij, wanneer de Padjangse vorst hem de keuze tussen beide gebieden laat. Aldus verklaart de Babad het zonderlinge geval. Doch de Serat Kanḍa, die minder geraffineerd is, blijkt toch enigszins onthutst te zijn over de geringe beloning van $\mathrm{kj}$. geḍé Pamanahan (Mataram) en laat die wat aanvullen uit de schatten van Kali-Njamat, „om te besteeden ten dienst van Mattarm” (p. 500).

Ten derde wordt dit schrale gebied, met slechts 800 tjatjah's (Serat Kanḍa 507) nog geweigerd ook, ten minste in de Babad. De verontschuldiging, dat de vorst van Padjang iets beters voor zijn onbevredigde vazal heeft bewaard, klinkt weinig overtuigend. Is de schenking van Mataram tòch niet van een leien dakje gegaan? Merkwaardigerwijze heeft ditmaal slechts de Babad dit verhaal; de Serat Kanḍa mist het.

Ten vierde lijkt het tapa-bedrijven van de teleurgestelde leenman haast een betuiging van misnoegen. Tapa, de verwerving van bovennatuurlijke vermogens, kan de inleiding vormen tot openlijk verzet tegen de bestaande hogere machten. Zo begonnen immers pg. Dipa-Nagara en vele anderen!

Ten vijfde ziet de aanwezigheid der Japaarse schone, voor de Padjangse vorst bestemd, doch aan $\mathrm{kj}$. geḍe Pamanahan (Mataram) toevertrouwd, er al heel verdacht uit. Naderhand blijkt zelfs diens zoon zich over de a.s. bruid van zijn vader, heer en leermeester ontfermd te hebben. Moet men nu heus maar geloven, dat deze jonge dame door de vorst van Padjang vrijwillig aan een vazal toevertrouwd, die zo pas door hem bitter gegriefd was? Of heeft hier een welgeslaagde schaking plaats gevonden? Dit zou in het geheel niets vreemds in kratonkringen zijn. De buitenlandse berichten, waarop wij terugkomen, spreken ook een gans andere taal.

Kortom, de voorstelling in de officiële kronieken ziet er al heel weinig aannemelijk uit. Pogen wij thans ons historisch beeld te verscherpen door het raadplegen van andere, buitenlandse bronnen. 
Gelijk wij reeds zagen, schrijft met name de West-Javaanse traditie aan de Matarammers een zeer bescheiden afkomst toe. Hiermede staat ongetwijfeld in verband, dat vanuit dezelfde hoek hun geen vreedzame verwerving, doch een gewelddadige verovering van Mataram wordt geweten.

Reeds Jan Pietersz. Coen meende, dat de stichter van het huis in de eerste plaats zijn fortuin te danken had aan zijn ,cloecheyt in wapenen ende verstandt" (Kron. Hist. Gen. 1853, p. 126/27).

Jac. Couper (D. 1 Oct. 1684) vermeldt dat kj. geḍe Pamanahan, nadat hem de grond te heet onder de voeten was geworden en hij buitenslands een toevlucht had moeten zoeken, roverhoofdman was geworden en de „negorij Mataram” had vermeesterd, naar welke hij zich sedert noemde.

Fr. Valentijn (IV, 72), die uit een gelijksoortige bron putte, geeft nog meer bijzonderheden. $\mathrm{Na}$ door de vorst van Padjang uitstekend ontvangen te zijn, vergold $\mathrm{kj}$. gẹ̣e Pamanahan goed met kwaad, roofde des sultans bezit, schaakte zijn bijwijven, die hij daarna aan gemene dorpelingen verkwanselde. Afgewezen door Tjerebon's beschermheilige, sunan Gunung Djati, daalde hij tot het peil der buffeldieven af, werd tot roverhoofdman over 40 of 50 dier gasten verkoren. Toen de bende 300 koppen telde, wierp hij zich tot vrijbuiter op. Daarop volgde de gewelddadige inbezitneming van het dun bevolkte Mataram.

De tolk H. v. d. Horst (Biäng-Lala IV 1855, p. 262-81), die ook uit West-Javaanse bron putte, geeft een iets gunstiger lezing van het geval. Daarbij verwart hij Sénapati met zijn vader, welke fout wij herstellen.

Kj geḍe Pamanahan was als aanvoerder van de koning van Padjang naar Mataram gezonden, om deze streek tot de Islam te bekeren (dus met geweld). Daarbij beging hij een misslag en besloot toen, na de zege op Mataram, aldaar te blijven en zich te tooien met de titel van Sénapati ing Mataram. De „bekering” is dus nog al hardhandig geschied. Trouwens, destijds wordt vaker een veroveringstocht als geloofsuitbreiding verheerlijkt. (Vgl. Sadjarah Bantĕn zang XXXV en V. Goens p. 357).

Aan het heilige karakter van déze oorlog, die tot de verovering van Mataram leidde, hebben wij dus ook zeer ernstige reden om te twijfelen.

Samenvattende kunnen wij dus vaststellen, dat deze West-Javaanse kijk op de Mataramse zaken allerminst te verwaarlozen is, ook al komt 
hij niet van bevriende zijde. Volgens deze beschouwing zou kj. geḍé Pamanahan zich met geweld van het landschap Mataram hebben meester gemaakt.

$\mathrm{Bij}$ deze West-Javaanse getuigenissen zouden wij nog de mededeling uit de Sadjarah Bantěn (20) kunnen voegen, verhalende, dat de stiefbroeders Pandjuwed en Pamanahan, zonen van kj. Bondan Kadjawan, in dienst traden bij de vorst van Padjang. De eerste kreeg Mataram, de tweede Pați (in werkelijkheid net andersom). Meer wordt er niet verteld. Het belang van dit korte berichtje schuilt vnl. daarin, dat het wschl. geput is uit een oudere, ons verloren redactie van de Babad Tanah Djawi, vermoedelijk uit de laatste jaren van sultan Agung. Het verhaal omtrent de toekenning der beide landen, Pați en Mataram, deed dus reeds omstreeks 1640 de ronde.

Wanneer wij thans pogen, de rol der z.g. lieden van Séla tijdens het rijk van Padjang nader te omschrijven, komen wij tot een vrij teleurstellende slotsom. De strijd tussen Padjang en Djipang-Bodjonagara moge hebben plaats gevonden, het aandeel der voorzaten van het Mataramse huis aan deze kamp staat allesbehalve vast. Daardoor komt tevens de toekenning der beide landen voor bewezen diensten op losse schroeven te staan, wat ook sommige Javaanse bronnen ons mogen suggereren. De oude en vrij stellige berichten omtrent een gewelddadige verovering van met name Mataram lijken veel aannemelijker. Wij hellen er daarom sterk toe over, deze als de oorspronkelijke te beschouwen. 


\title{
KJAI GEḌÉ MATARAM.
}

\author{
Karang-Lo.
}

Tijdens de reis van kj. geḍe Pamanahan, thans kj. geḍé Mataram genoemd, naar zijn nieuwe gebied, werd hij volgens de Babad (66) onthaald door kj. geḍé Karang-Lo.

De uittocht uit Padjang was schilderachtig en weinig voornaam. $\mathrm{Kj}$. gedé Mataram liep voorop, daarna zijn vrouw en kroost in een lange rij, belast en beladen. „Van al wat in een huishouding nodig is, bleef niets achter." Geen wonder, dat ze langzaam opschoten. Eindelijk kwamen ze bij de grens, in Tadji en rustten uitgeput onder de waringin.

Een plaatselijke grote, $\mathrm{kj}$. gedé Karang-Lo trok met zijn vrouw de vermoeiden tegemoet en onthaalde hen op kippenpetjel en djangan menir, ,als geneesmiddel tegen vermoeidheid."

Terwijl hij gezelschap tot aan de kali Opak begeleidde, vroeg hij voortdurend om een gunst. In de Opak troffen zij net sunan Kali-Djaga aan het baden. Terwijl zij beiden hem daarbij assisteerden, voorspelde de heilige: „Weet, dat mettertijd de nakomelingen van ki Karang-Lo hier mede zullen delen in de weelde van uw nazaten, maar geen aanspraak zullen hebben op de titel van mas en radèn, of van een djempana of tandu ( $=$ draagstoel) gebruik maken."

Daar de figuur van kj. gẹ̣é Karang-Lo in de Serat Kanḍa ontbreekt, vervalt de reden tot een vergelijking met de Babad. Wij komen er hierna op terug.

Kj. geḍe Pamanahan's aftocht uit Padjang ziet er maar heel gewoontjes uit. Dit in tegenstelling tot de Serat Kanḍa (504) die nog een officiële piagem (acte) laat uitreiken. Is in dit armelijke vertrek soms een herinnering aan een guerilla-oorlog bewaard ? Ook de hulpverlening aan de uitgeputte zwervers past hierbij.

Tadji zal later een der befaamde tolpoorten van Mataram worden. Een Karang-Lo ligt o.a. in het Noord-Jogjase. Is dit een vroegere vrijheerschappij geweest?

In de Sadjarah Dalem komt ook de stamboom van Karang-Lo voor 
(gen. 145-59). Deze begint natuurlijk bij Demak, doch dit ziet er wel echt als makwerk uit. $\mathrm{Kj}$. ageng Karang-Lo Tadji moet dan wel de landheer zijn, die de vermoeide zwervers zo vriendelijk onthaalde (gen. 151).

De volgende vijf generaties bevatten geen klinkende namen, juist zoals sunan Kali-Djaga voorspelde, dus zonder een enkele mas of radèn. Ook gaat het geslacht wel eens over in de vrouwelijke lijn. Doch eindelijk komt men bij kj. tg. Wira-Redja, die elf kinderen bezat (gen. 157), waarvan het derde was kangdjeng ratu Kentjana, genaamd: kangdjeng ratu Beruk, gemalin van sunan Paku-Buwana III en moeder van PakuBuwana IV.

Vanwaar deze snelle promotie? Hieromtrent deelde dr. Poerbatjaraka mij de volgende Solose overlevering mede.

De gemalin van de derde Paku-Buwana begon haar loopbaan zeer nederig als handelaarster in houtskool in de wijk Tjojudan (Solo). Haar vader woonde in bij een vriend, wiens taak het was, de vorst verzen voor te lezen. Toen deze voorlezer eens door ongesteldheid verhinderd was, zijn plicht te vervullen, verving hem zijn huisgenoot, en wel met zoveel succes, dat de sunan hem tot hofvoorlezer benoemd. Dit bracht mede, dat diens dochter onder de bedaja-danseressen werd opgenomen, en nu was het nog maar één schrede, om als hoofdgemalin des sunans haar intocht in de kaputrèn te doen. De vorige hoofdvrouw werd eenvoudig verstoten. Volgens de Nederlandse berichten (d. J. X, 388—89; XI, 32) had dit huwelijk omstreeks 1762 plaats.

Hieraan hebben wij ongetwijfeld de fraaie titels te danken, waarmede sedert haar familie pronkt. De negen radèns onder haar broeders en zusters logenstraffen afdoende de voorspelling van sunan Kali-Djaga, terwijl voorzeker ook het gebruik van draagstoelen aan deze aristocraten niet vreemd zal gebleven zijn. Die voorzegging moet daarom alleen maar betrekking kunnen hebben op de vijf onbeduidende generaties tussen kj. ageng Karang-Lo Tadji en de ratu Kentjana. Daarom zal deze voorspelling van vóór 1762 moeten dateren.

In de oudere Serat Kanḍa ontbreekt deze Karang-Lo-episode. Dat deze oudste geschiedenis toch niet geheel uit de lucht kan gegrepen zijn bewijst wel de korte vermelding daarvan in de Sadjarah Bantěn (30), waar onder de vrienden en vertrouwden van Sénapati genoemd worden: (zijn oom) ki Djuru-(Martani) en de hoofden van Karang-Lo en Anḍaptulis. De laatste komt in de Babad (65) voor onder de naam van aria Daḍaptulis van Padjang, schoonzoon van $\mathrm{kj}$. Pamanahan. Deze blijft met nog een andere schoonzoon, tg. Majang in Padjang achter. 
$\mathrm{Kj}$. geḍe Mataram behield daar dus een kleine kring van aanhangers, die hem later goede diensten zouden bewijzen ${ }^{1}$ ).

Sunan Kali-Djaga, die daar opeens aan de kali Opak opdook, verdween even plotseling, als hij gekomen was, om pas veel later weer enige malen voor het voetlicht te treden (Babad 82 en 106).

In de Serat Kanda is de grote heilige slechts door zijn zoon, susuhunan Adi vertegenwoordigd, die aan dezelfde rivier Opak de landverhuizers de plek der nieuwe hoofdstad aanwijst, t.w. aan de NoordWestkust der Zuidzee. Daarop zet deze heilige man zijn reis voort en hij zo min als zijn vader treden meer op.

Hier is wel een duidelijk verschil tussen beide kronieken. De Babad neemt een aantal bezoeken van sunan Kali-Djaga aan het Mataramse binnenland aan, welke de Serat Kanḍa niet kent. Daar de laatste wschl. ouder is, moet het spaarzamer optreden van sunan Kali-Djaga stellig oorspronkelijker wezen.

\section{Giring.}

De merkwaardigste ontmoeting, die kj. geḍe Mataram in zijn nieuwe land zou gehad hebben, was wel die met kj. geḍe Giring (Babad 67-69). Op grond van het ontbreken van deze naam in de Serat Kanḍa is deze geschiedenis vermoedelijk pas vrij laat in de Babad terecht gekomen. $\mathrm{Zij}$ luidt als volgt :

$\mathrm{Na}$ zijn vreedzame vestiging in Mataram onderbrak kj. geḍé Mataram zijn vlijtig voortgezette askese om een bezoek te brengen aan een boezemvriend in het Zuidergebergte: kj. ageng Giring of Padérésan. Ook deze beoefende de askese, blijkbaar met hetzelfde doel voor ogen als zijn vriend, n.l. de heerschappij over Java, óók voor zijn nazaten. In zijn dagelijkse doen was hij echter slechts een eenvoudige palmwijntapper.

Eens beloofde een stem uit een jonge klapper, de enige aan die stam, de macht over Java voor zich en zijn geslacht aan degenen, welke het vruchtwater dronk. Verheugd bracht Giring de onrijpe vrucht thuis en legde hem op een plank, daar hij nog geen dorst had. Na zijn vertrek kwam Pamanahan thuis, ontdekte de klapper en dronk hem tot de laatste druppel leeg. Dit baarde geen kleine ontsteltenis, hoewel Giring lang bleef zwijgen, „zoals voortreffe-

1) Over deze voorspelling, spreekt ook Poensen's Javaanse bron in zijn: Mangkubumi, Ngajogyakarta's eerste Sultan... (B.K.I. LII 1901, p. 269-70). J. W. Winter, in zijn Beknopte beschrijving van het Hof Soerakarta in 1824 (B.K.I. LIV 1902, p. 29), meent, dat de vader van deze „Den lorro berook”, „zekere hooge Priester Kiai Gedé Karang Loo”, toen in de „dessa' Tajie” woonde, „welke na de verheffing van $Z$ ijne dogter tot Ratoe Kentjonno direct Regent wierd, en genaamd Tommenggoong Wiro Redjo". 
lijke mensen doen." Ten slotte vroeg hij heel deemoedig, of zijn nakomelingen die van Pamanahan nooit eens zouden mogen aflossen. Na herhaald aandringen werd hun ten slotte genadig vergund als 7e opvolger over Mataram te heersen.

Dit verhaal speelt, zoals de Babad reeds vermeldt, in het Zuid-Jogjase en thans treft men nog een Giring in de gunung Kidul aan.

Bijna was de toezegging van $\mathrm{kj}$. geḍé Pamanahan aan zijn mededinger in vervulling gegaan, indien het ongeduld van kj. geḍe Giring's nakomelingen geen spaak in het wiel gestoken had.

De kluizenaar ki Wana-Kusuma, zich afstammeling noemende van $\mathrm{kj}$. geḍe Giring, bezat twee zonen, die het geduld misten om te wachten op de dood van Mangku-Rat II, de zesde heerser op de Mataramse troon. Daarna zou het immers hun beurt zijn! Daardoor mislukte hun opstand, de zonen sneuvelden en de vader verdween in het niet (Babad 241-44). Men leze over het werkelijke verloop van deze opstand (sedert 1681) het slot van mijn Kadjoran-vraagstuk (Djawa XX, 1940).

De toespelingen in het verhaal van $\mathrm{kj}$. geḍé Giring op deze gebeurtenissen tijdens sunan Mangku-Rat II maken het onmogelijk, dat het voor het einde der $17 \mathrm{e}$ eeuw aldus te boek is gesteld.

Gelijk vele rebellen, stamt ook dit geslacht van het weinig Mataramsgezinde Tembajat af. Ontdaan van alle bijwerk blijft dus over, dat ook in het Mataramse oude families woonden, die kj. gedé Pamanahan en de zijnen als indringers en mededingers beschouwden, welke inbreuk maakten op hun oude rechten. Een geestelijk steunpunt vond deze oppositie in het pelgrimsoord Tembajat.

\section{Verblijf in Mataram.}

Omtrent het verder verblijf van $\mathrm{kj}$. geḍe Pamanahan in Mataram weet de Babad (66-67) slechts opgewekte dingen te vertellen:

De natuur werkte mede door overvloedige opbrengst. Zelfs het putwater was helder. De handel bloeide. Veel mensen vestigden er zich.

$\mathrm{Ki}$ Pamanahan veranderde zijn naam in ki ageng Mataram en leidde met de zijnen een onbezorgd leven. Doch hij bedreef tapa, „omdat hij bekend was met de voorspelling van sunan Giri, dat er later in Mataram grote vorsten zouden optreden, die over geheel Java zouden regeren." Hij hoopte, dat het dan zijn nakomelingen zouden wezen.

Hierbij valt het volgende op te merken:

Dat de natuur in overeenstemming werkt met een goede of slechte 
regering, is een algemeen verbreide opvatting, die zich niet tot Java beperkt. De aanwezigheid van handelaars is opmerkelijk. Heeft er een zekere maatschappelijke verandering in de landelijke Mataram plaats? Pigeaud wees op iets dergelijks in zijn Volksvertooningen, par. 366.

Het tapa bedrijven om iets te bereiken, is in het oude en nieuwe Java nog zeer goed bekend. Raadselachtig is daarentegen de vermelde voorspelling van sunan Giri, die wij niet kennen. Wel komt zij later voor.

De voorstelling in de Serat Kanda (516-18) bevat iets meer realiteit:

Bij zijn komst in Mataram ontbiedt ki Pamanahan alle 800 tjatjah's en maakt hun de piagem van de vorst bekend. Daarop erkennen zij hem als hun hoofd.

Op een vast gestelde dag beginnen de inwoners op Pamanahan's bevel het bos te kappen en een dalem te bouwen. De wegen worden met vruchtbomen beplant. Deze opbouw geschiedde in 1513 (A.D. 1591).

Opvallend zijn hier de piagem van de vorst en de erkenning door het volk, die de Babad mist. Java is soms democratischer, dan het lijkt. Zijn dit soms Mantja-Nagarasche invloeden?

Over kj. geḍé Pamanahan's verblijf in Mataram bezitten wij één Nederlands bericht, geput uit een Tjerebonse bron, dat al het lieflijke en vreedzame in de bovenstaande voorstellingen, logenstraft, t.w. het al eerder aangehaalde „Verhaal van het geslagt der Cheribonse princen, en tegenwoordigen Sousouhounang.... door Jac. Couper" (Dagreg. 1 Oct. 1684).

Deze verhaalt het volgende:

Nadat kj. geḍé Pamanahan zich „over eenige misdaat” uit de voeten had moeten maken en boswaarts begeven, ,waar hij een zamenrottinge maakten van een parthije schelmen en dieven” legde hij het „op een stroopen en steelen aan.... versamelde een groote quantiteijt volck, daar hij de negorije Mataram mede vermeesterde en hij de naam van Keij Gede Mattarm kreegh. Het geluck hem gunstig zijnde, kreegh een groote aanhangh en niet minder ontsag, zoo dat hij binnen korten tijd zigh meester maakte van de omleggende plaatsen, en dwong met gewelt de negorie Jipangh, Panaraga, Canbang en Coerij (of Coenij)."

$Z_{0}$ vreedzaam als de berichten uit de officiële kronieken zijn, zo krijgshaftig zijn die uit Tjerebon. Van kraton-stichting geen woord; wel veel over veldtochten naar streken, waarvan men in Mataram destijds nog niet droomde. Canbang en Coerij (Coenij) is misschien een verbastering van Kembang-Kuning, zoals verschillende dessa's heten, waardoor wij er weinig houvast aan hebben. Kennelijk zijn vroe- 
gere en latere veroveringen der Mataramse vorsten dooreen gehaald.

\section{Datering der stichting van Mataram.}

Een lastig probleem is de chronologie van dit tijdperk. De verschillende jaartallenlijsten vertonen juist hier bedenkelijke gapingen.

De Babad Sengkala heeft tussen A.J. 1480 en 1499 (A.D. 1558 en 1577) niets. De Babad Sangkalaning Momana ziet er juist voor deze tijd zo fantastisch uit, dat er geen staat op te maken valt. In de Chronological-Table van Raffles ligt de gaping tussen A.J. 1478 en 1499 (A.D. 1556 en 1577). Hageman heeft wel in de leemte trachten te voorzien, door er een paar jaartallen uit andere bronnen tussen te schuiven, maar toch vertoont zijn Tijdrekenkundig overzigt (Handleiding I, 116-19) een gat van A.D. 1554 tot 1579. Dus juist voor het tijdperk, waarin de opgegeven feiten in Babad en Serat Kanḍa voor ernstige kritiek vatbaar zijn, ontbreken de jaartallen. Nemen wij de opening zo klein mogelijk, dan is dit juist 1558 tot 1577 . Wij zagen reeds, dat in het eerstgenoemde jaar waarschijnlijk pg. aria Panangsang ten val en de lieden uit Séla de landen Pați en Mataram kregen tot loon voor hun daarbij bewezen diensten.

Maar ook het jaartal 1577 is voor Mataram belangrijk, aangezien omstreeks dat jaar volgens de latere overlevering de kraton zou gesticht zijn. Volgens de Babad (174) bestond het rijk Mataram bij de val van de kraton Plèrèd juist een eeuw. Daar deze kraton op 29 Juni 1677 viel, dienen wij van deze datum af terug te tellen, hoewel wij niet weten waarmede: zonne- of maanjaren. Vermoedelijk beide, dus vóór 1633 zonne-, daarna maanjaren. Dan komen wij tot het jaar 1578. Aan deze stichting zou dus een 20 -jarig tijdvak van strijd en verwarring zijn vooraf gegaan.

Hoe lang heeft kj. geḍé Pamanahan na de stichting van de Mataramse kraton daar nog in gewoond?

Volgens het reeds aangehaalde bericht van Jacob Couper zou hij nog zes jaren in Mataram geleefd hebben.

Is het jaartal 1578 juist, dan brengt ons dat tot het jaar 1584 als het sterfjaar van kj. geḍé Pamanahan en het optreden van zijn zoon Sénapati, hetgeen, gelijk wij zien zullen, wel met de overige bekende jaartallen te harmoniëren is ${ }^{1}$ ).

1) Dit jaar 1584 verschilt maar weinig met het jaar 1583, dat volgens de opvatting van J. W. Winter-G. P. Rouffaer het laatste van Kjai Geḍé Mataram's regering zou geweest zijn (B.K.I. LII 1901, p. 102 noot 17). 


\section{PADJANG IN DE OOSTHOEK.}

\section{Omvang van het Padjangse rijk.}

$\mathrm{Na}$ de val van pg. aria Panangsang, heer van Djipang, zullen wij ons Padjang's invloedssfeer ongeveer als volgt dienen voor te stellen.

In het binnenland beheerst het Padjang, het huidige Sura-Karta, terwijl over Madiun een aan het Padjangse hof opgegroeide heerser het bewind voerde, pg. Timur, later panembahan genaamd.

Mataram (Jogja-Karta) was in handen van zijn vazal, kj. geḍé Pamanahan en dit kon men dus ook nog tot het Padjangse machtsgebied rekenen. Hoe ver dit zich nog verder Westelijk uitstrekte, is onbekend.

Aan de stranden waren de rijken Prawata (Demak) en Kali-Njamat (Djapara) door de ratu Kali-Njamat aangeboden, dus min of meer onder Padjang geraakt, al zal dit haar gezag niet al te zeer geschaad hebben. Sedert pg. aria Panangsang's nederlaag stond ook Djipang (BodjoNagara) onder Padjang, terwijl het blijkbaar ook over Pați te zeggen had, daar het dit gebied aan een vazal kon afstaan. Zo bestreek de Padjangse hegemonie een brede strook lands van Noord- naar Zuidkust.

Heeft Padjang zijn heerschappij nog verder uitgebreid over Westof Oost-Java? Latere getuigenissen van vreemdelingen veronderstellen een zich over bijkans het gehele eiland uitstrekkend gezag. Hoe dit zich gevestigd heeft, is in vele opzichten duister. Over zijn uitbreiding Westwaarts weten wij bijna niets; over die in Oostelijke richting slechts een weinig.

Opvallend is, dat Padjang zijn gezag niet over zee heeft kunnen uitbreiden - een kenmerk voor een landstaat. Zelfs Madura ontbreekt!

Bandjermasin, dat volgens het getuigenis der Kroniek van die plaats (Cense 46) steeds gezantschappen naar Demak zond, om hulde te betuigen, staakte dit gebruik, toen de sultan Surja Alam van Padjang vele Javaanse landen onderwierp.

Palembang, eertijds nauw met Demak verbonden, blijkt, gelijk wij zien zullen, een toevluchtsoord te worden voor hem, die Padjang's heerschappij te duchten hebben. Padjang zal er daarom niets te zeggen hebben gehad.

Zelfs van een Padjangse invloed op het Oostelijke Balambangan merken wij niets. Op grond der spaarzame tijdingen moet dit rijkje 
steeds zijn onafhankelijkheid hebben kunnen bewaren. Blijkens een bericht van 1559 had Balambangan het zwaar te verduren, omdat het nog geheel heidens was. Vóór 1575 moet Panarukan verloren zijn gegaan, omdat het in dat jaar werd herwonnen door vorst Santa Guna, en wel met hulp van Bali en Sumbawa. In 1584 begonnen de Portugezen er het Christendom te verbreiden (vgl.: M. Neyens, De geheimzinnige klok. T.B.G. LXXVI 1936, 81).

\section{„Pate Sudayo" van Sura-Baja.}

Vestigen wij thans onze aandacht op Sura-Baja.

De Portugees Pinto verhaalt, hoe na de vermoording van de vorst van Demak door de jeugdige zoon van „Pate Pondan”, heer van SuraBaja, niet enkel de schuldige, doch ook zijn vader, drie broeders en 62 verdere familieleden wredelijk ter dood gebracht werden, zodat het hele geslacht was uitgeroeid (Peregrinação CLXXVII).

$\mathrm{Na}$ veel geharrewar kozen de acht rijksgroten te Japara ten slotte tot „Pangueyram” (= keizer) een zekere „Pate Sudayo”, prins van Sura-Baja, die zich bevond in een plaats "Pisammanes”. Vandaar werd hij naar Demak ontboden en met grote geestdrift ontvangen, en men verhief hem tot „Pangueyram” van gans „Iaoa, Bale” en Madura. Daarop vestigde hij zich in Demak, door de burgerkrijg zwaar gehavend, terwijl hij krachtig de orde poogde te handhaven (ibid. CLXXIX).

In deze Pate Sudayo heeft men een heer van Sidaju willen zien, wat enigszins ongerijmd is, omdat men niet heer van Sidaju kan heten en tevens heer van Sura-Baja kan zijn. Sudayo is dan ook de naam van een persoon, niet van een plaats. Welke Javaanse naam kan hier achter schuilen?

$\mathrm{Nu}$ bezit het Kon. Bataviaasch Genootschap een handschrift (Ms. Br. 474), dat een lijst van heersers over Sura-Baja bevat.

Als no. 9 van die reeks komt daar een pg. Sundjaja voor, wat inderdaad enige klankovereenkomst met Sudayo vertoont. Daar staat echter tegenover dat op deze Sundjaja dadelijk pg. Pekik volgt, welke in 1659 vermoord is, zodat enige generaties moeten zijn overgeslagen.

Wat er verder met deze pate Sudayo - pg. Sundjaja gebeurd is, bleef onbekend. Slechts geeft de genoemde Sura-Bajase stamlijst hem een voorvader in de heilige van Ngampèl-Denta: susuhunan Rahmat. M.a.w. de 17 e eeuwse vorsten van Sura-Baja beschouwden zich volgens de samensteller van deze lijst, als nazaten van sunan Rahmat van Ngampèl-Denta. 
Hiervoor pleit meer. Pg. Pekik bovengenoemd, zou volgens de Babad (p. 139) ,een afstammeling van een pandita” zijn. Welke, wordt niet vermeld, maar de dichtstbijzijnde is rd. Rahmat.

Bovendien blijken de afstammelingen van pg. Pekik voor rd. Rahmat juist zo'n bijzondere verering te hebben. (Brief uit Sura-Baja dd. 18 Sept. 1691). In optocht trekken zij naar zijn graf en hebben er zelfs een vechtpartij met hun politieke tegenstanders voor over!

Wij kunnen dus wel aannemen, dat het vorstengeslacht, dat ten minste sedert het laatste kwart van de 16e eeuw over Sura-Baja heerste, zich een afstamming van rd. Rahmat van Ngampèl-Denta toeschreef.

Op den duur werd Sura-Baja de machtigste staat van Oost-Java, een waardige tegenstander voor het opkomende Mataram. Over de uitbreiding van dit rijk tot zelfs buiten Java, zullen wij elders spreken. Evenzo over zijn groeiende economische betekenis.

Als nazaat van het grote Madja-Pait herbergde het ongetwijfeld een deel der oude Javaanse cultuur. Tot in de 20 ste eeuw kon men er sporen der oud-Javaanse bouwkunst onderkennen. Over pg. Pekik, zoon van de laatste Sura-Bajase koning, als overdrager der Oost-Javaanse letterkunde naar Midden-Java, hopen wij in een volgend deel te spreken. Slechts vestigen wij er nu de aandacht op, dat men er in Sura-Baja naar gestreefd heeft, de oude Javaanse overleveringen te verzamelen tot een geheel, een soort Sura-Bajase rijkskroniek, die ons niet bewaard bleef, doch waarvan ongetwijfeld belangrijke gedeelten in de huidige Babad Tanah Djawi zijn te herkennen.

\section{Lemah Duzeur van Madura.}

Het schijnt, dat in het derde kwart der 16e eeuw Madura een zekere rol heeft gespeeld.

Wij dienen hiertoe, bij gebrek aan beter, bij uitzondering een vrij troebele bron aan te boren, t.w. Hageman's Handleiding. Deze keuze wordt enigszins gerechtvaardigd door de overweging, dat deze amateur tot Javaanse geschriften toegang had, welke nu voor ons onbereikbaar, mogelijk zelfs verloren zijn, doch wellicht enig vertrouwen verdienden.

Tot op zekere hoogte geldt hetzelfde ook voor Raffles' History of Java, dat ook op verschillende, niet bij name genoemde Javaanse bronnen teruggaat.

Raffles dan bericht, dat de toenmalige heerser op Madura, schoonzoon van sultan Trenggana, geheerst heeft over: Madura, Sumenep, Sidaju, Gresik en Pasuruhan, dus over een Groot-Madura.

Hageman noemt dezelfde gewesten als erfdeel van de Madurese vorst, 
geheten panembahan Lemah Ḍuw (Handleiding 66). Deze zou volgens zijn vorstenlijst van 1531 tot 1592 geregeerd hebben. Dit is weliswaar een heel lange tijd, doch onze andere gegevens zijn er niet mede in strijd.

Jammer, dat deze voorstelling zo gebrekkig ondersteund wordt door de Geschiedenis van het vorstenhuis van Madoera, uit het Javaansch vertaald door W. Palmer van den Broek (T.B.G. XX 1871, 241 en vlg.), waar men leest: „Geheel Madoera was aan hem onderworpen.... ook Malaja en Balega had hij zich met geweld onderworpen." Van Madurese bezittingen op het Javaanse vasteland wordt evenwel niet gerept. Was dat, omdat dit bezit weer verloren gegaan is? 's Mans naam ontbreekt ook in Truna-Djaja's opsomming zijner voorzaten (d. J. VII, 92-93). Wellicht verzweeg hij deze voorouder, omdat deze zijn Javaans bezit weer was kwijt geraakt, wat voor iemand, die beoogde minstens heel Oost-Java in de zak te steken, een kwaad voorteken was.

Ook Hageman (Handleiding 70) beweert stellig, dat Madura zijn bezit aan de Javaanse overwal aan Padjang kwijt is geraakt. Dit laatste zou zich van vele gewesten in Oost-Java hebben meester gemaakt, waarbij, doch in andere volgorde, dezelfde genoemd worden, die Raffles als veroveringen van Madura vermeldt, en onze amateur besluit: „De meesten der bovengemelde strandlanden behoorden onder Madura, dat zijne onafhankelijkheid bleef behouden."

Hiermede strijdt niet Couto's later te bespreken lijst der Padjangse onderhorigheden, waarop Madura ontbreekt (Da Asia IV dec. III lib.) vermeld door Rouffaer in Album-Kern 1903 p. 267-74).

Voor een bevriende, doch enigszins onafhankelijke positie van Madura t.o.v. Padjang pleit ook het huwelijk van pan. Lemah-Duwur met een Padjangse prinses (Sadjarah Dalem gen. 166), uit welke echtverbintenis zes zijner vijftien kinderen sproten, onder wie de beide troonopvolgers.

\section{Padjang's zege over Oost-Java.}

$\mathrm{Nu}$ zullen de strijdbare Madurezen zich niet zo gemakkelijk naar hun eiland hebben laten terugdrijven. Hageman (Handleiding 70-71) laat erkenning van de Padjangse vorst door de drie op Madura veroverde gewesten: Sidaju, Gresik en Pasuruhan, zo mede door Tuban, WiraSaba, Kediri, Pana-Raga, Madiun, Blora en Djipang, met enige luister, als ware het een zegepraal geschieden. De sultan verscheen, gezeten op een olifant en omstuwd door zijn rijksgroten, voor het aangezicht van de priestervorst van Giri. Op dit bezoek aan de geestelijke komen wij naderhand terug (p. 62). 
$\mathrm{Na}$ de erkenning van Padjang's opperheerschappij werd door de staten van Oost-Java als algemeen landvoogd gekozen de adipati van Sura-Baja, Pandji Wirja-Krama. Mogelijk had deze zich tegen de Madurezen kunnen handhaven.

Ofschoon deze naam ook bij Raffles voorkomt (History p. 143) weten we verder niets meer van deze Pandji Wirja-Krama.

Zijn aanstelling door de vorst van Padjang heeft vermoedelijk een blijvende band tussen dit rijk en Sura-Baja gelegd. Immers, na de totale ondergang van Padjang in 1617 begeeft de dipati van die plaats zich met zijn rechterhand ki Tambak-Baja naar Sura-Baja, waar zij welkom zijn (Babad 132). En wanneer na de val dier stad de zoon van SuraBaja's laatste koning overnacht bij het graf van sultan Padjang te Butuh, verneemt hij daar in de slaap de latere grootheid zijner nazaten (Babad 137). Bij de keuze van een plaats voor zijn nieuwe kraton laat Mangku-Rat II zich door deze voorspelling leiden (Babad 205).

Moeilijk te beantwoorden is de vraag, waar Raffles en Hageman hun Pandji Wirja-Krama vandaan hebben. Gelijk gebruikelijk in die dagen noemt geen van beiden zijn zegsman.

Tevens valt op, hoe spaarzaam de Sadjarah Dalem is met genealogische bijzonderheden betreffende de grootvader van Mangku-Rat II, pg. Pekik van Sura-Baja. Zij komt niet verder dan zijn vader, die dan radèn Pandji Djaja-Lengkara heet (gen. 157, 9; 217).

Deze soberheid is zo opvallend, dat wij wel aan een later ingrijpende censuur moeten denken. Onkunde kan het niet geweest zijn, want tg. Tirta-Wiguna, een der schrijvers van de Babad, moet in Sura-Baja goed thuis geweest zijn (Sadjarah Bantěn 222).

Ogenschijnlijk zou er alle reden toe geweest zijn, om pg. Pekik van een fraaie stamboom, echt of onecht, te voorzien. Doch de tak der Matarammers, waarvan hij de stamvader was, eindigde bij MangkuRat III of sunan Mas. Deze werd door zijn oom van de troon gestoten, die daarop als Paku-Buwana I plaats nam. Van hem stammen alle volgende vorsten af, terwijl de afstammelingen van Mangku-Rat III of als ballingen naar Ceylon gingen, of leiders der oppositie werden, zoals de ongelukkige mas Garendi of sunan Kuning.

Het lag dus voor de hand, om het voorgeslacht der tegenstanders van de regerende tak niet al te luisterrijk af te schilderen. Daarom ligt een verminking van hun stamboom voor de hand. Zelfs is het mogelijk, dat deze reeds eerder heeft plaats gevonden, b.v. in de $2 \mathrm{e}$ helft der regering van sultan Agung, toen de Matarammers nog verbitterd waren over de 
langdurige strijd met de erfvijand Sura-Baja. De schrijver van Babad blz. 139 kende de stamboom der Sura-Bajanen vermoedelijk nog in zijn geheel, doch verzweeg hem. Pg. Pekik stamde eenvoudig van een pandita af! Met deze heilige man zal sunan Rahmat van Ngampèl-Denta bedoeld zijn. Mogelijk is daarom ook Pandji Wirja-Krama een dier figuren uit de gesnoeide stamboom.

\section{Sunan Parapèn van Giri.}

Behalve met Sura-Baja, waarover in de Babad nauwelijks gerept wordt, heeft Padjang te maken gehad met de priestervorst van Giri. Het bezoek aan deze geestelijke heeft niet nagelaten indruk te maken en wordt in alle bronnen met veel zwier verhaald. Bij uitzondering wordt zijn naam in de Babad vermeld: Susuhunan Parapèn, die de kleinzoon wordt genoemd van de sunan Giri (zonder meer). Met de laatste wordt ongetwijfeld bedoeld radèn Paku of Prabu Satmata.

Een stamboom, voorkomende in een handschrift uit het begin der 19e eeuw, getiteld: Uit de overlevering van het geheiligde graf Giri te Grissee (Ms. Kon. Inst. H 141) geeft als zoon van deze eerste sunan Giri: sunan Dalem. Deze werd opgevolgd door zijn zoon, sunan SéḍaMargi, die blijkbaar slechts kort aan het bewind was en vervangen werd door zijn jongere broeder, sunan Parapèn. Volgens Wiselius was hij van 1553 tot 1587 aan het bewind, hetgeen in grote trekken met onze overigens zeer schaarse gegevens overeenstemt ${ }^{1}$ ).

Deze sunan Parapèn moet een grote roerigheid ten toon gespreid hebben, niet slechts op Java, doch ook tot ver in de Archipel.

Op Lombok wordt hem door de Sasaks de invoering van de Islam toegeschreven (Adatrechtbundels XV: Bali en Lombok, P. de Roo de la Faille, Studie over Lomboksch Adatrecht p. 136-37). Met geweld zouden de bewoners tot de nieuwe godsdienst gebracht zijn, zodat de vorst van Lombok daarin aanleiding vond, zijn zetel naar Sélaparang te verplaatsen.

Mogelijk heeft hij ook te maken met een poging der Javanen, om de Islam op Bali wortel te doen schieten, vermeld in de Kidung Pamancangah, waarvan C. C. Berg's proefschrift: De Middeljavaansche historische traditie, een uittreksel bevat.

1) G. P. Rouffaer, Encyclopaedie-artikelen (Giri) B.K.I. d1. 86 (1930), p. 207 verbetert dit in $\pm 1546-1605$, o.a. door deze susuhunan Parapèn gelijk te stellen met de 120 jaar oude „opperste Priester der Indianen in Java”, welke de wereldomzeiler Olivier van Noort in Febr. 1601 een eind weegs buiten Gresik aantrof (ibidem 205). 
De vorsten van Mataram en Pasuruhan zouden een spotdicht op Bali's oppervorst Batu-Renggong gemaakt hebben, waarin zij hem met een opgehitste vechtkrekel hadden vergeleken. De beledigde was hierover heel boos en liet dit spotvers beantwoorden door een ksatriya Den Takmung. In dit antwoord werd herinnerd aan de komst van een gezant uit Mekka, die de koning schaar en scheergerei had aangeboden en hem tot de Islam wilde bekeren. De geschenken waren toen vernield en de gezant danig afgestraft.

Hierbij dienen wij op te merken, dat men de aardrijkskundige benamingen als Mataram of Mekka niet al te letterlijk moet opvatten. Het beeld, dat de Baliërs van de wereld buiten hun gezegend eiland hadden, was niet scherp omlijnd, doch dat Batu-Renggong een tijdgenoot van sunan Parapèn was, staat vast. Hoe zou deze laatste, die Lombok wilde bekeren, het tussengelegen Bali hebben kunnen overslaan!

De Islam heet op Makassar te zijn gebracht door een Minangkabauer uit Kotatengah: Dato' ri Bandang, van wiens afkomst verder niets bekend is (R. A. Kern, De verbreiding v/d Islam, in: Stapel, Gesch. v. N.I. dl. I, 356-57). Doch volgens dr. Cense bevat een Javaanse Babad Lombok, waarvan dr. Poerbatjaraka hem destijds een inhoudsopgave bezorgde, een bericht, dat deze zendeling als leerling van Susuhunan Giri zijn bekeringsarbeid heeft verricht. Dus zou toch Giri een aandeel in de bekering van Z.W.-Celebes gehad hebben!

In 1565 sloten de bewoners van het Ambonse schiereiland Hitu een verbond met de Radja Giri of Bukit (= berg) en wel tegen de Portugezen. De priestervorst zond de Hitu-ezen Javaanse hulptroepen toe, die zich op een plek legerden, welke nog lang daarna "Cotta Java" heette. $\mathrm{Na}$ er drie jaren gelegen en wat geplunderd te hebben, keerden deze scharen onverrichterzake naar Java terug (Val.II Amb.Zaaken 19).

Ook in latere jaren blijken de banden tussen Hitu en Giri nog zeer hecht te zijn, tot ver in de $17 \mathrm{e}$ eeuw. ${ }^{1}$ )

1) Van Giri's bemoeienis met het binnenland weten wij weinig of niets. Dat weinige putten wij uit een drietal vage berichten, voorkomende in de Babad Sengkala, en bij Raffles en Hageman, die het overwegen wel waard zijn.

Het eerste luidt in de Babad Sengkala 1470 (A.D. 1548) : de vorst van Giri gaat naar Kediri: bij Raffles: 1471 (A.D. 1549): Arrival of the prince of Giri in the district of Kadiri; bij Hageman: 1552 Kediri door Giri veroverd. Ongetwijfeld wordt in alle drie de gevallen hetzelfde feit bedoeld, n.1. een reis van de priestervorst naar Kediri, waarvan Hageman slechts een wat vrijere interpretatie geeft. Wat dit voor een reis is geweest, weten wij niet, missionair of militair? 


\section{Padjang's reis naar Giri.}

Deze susuhunan Parapèn van Giri is bezocht door de vorst van Padjang, waarvan wij in Babad 70-72 de volgende beschrijving vinden :

Sultan Padjang trok met zijn hele leger naar Giri, om sunan Parapèn toestemming te vragen voor zijn optreden als sultan. $\mathrm{Ki}$ ageng Mataram (Pamanahan) ging ook mee. Toen waren alle bupati's uit het Oosten aanwezig, n.l. die van Djapan, Wira-Saba, Keḍiri, Sura-Baja, Pasuruhan, Madiun, Sedaju, Lasem, Tuban en Pați, ondergebracht in tijdelijke logeergebouwen.

Toen kwam sunan Parapèn naar buiten, om gehuldigd te worden. De vorst en zijn volk maakten naar rangorde hun opwachting. Hij werd geroepen, wat dichterbij te zitten en tot sultan AdiWidjaja van Padjang uitgeroepen, ook met toestemming van de priestervorst. Dit geschiedde in 1503 (A.D. 1581).

Daarop volgde een maaltijd, waarbij de priestervorst een preek hield. Nadat de bupati's gegeten hadden, kregen de ondergeschikten de rest. Pamanahan liet daarbij de anderen voorgaan, wat de aandacht van sunan Giri trok. Deze liet hem naderbij komen en sprak een voorspelling uit: de nakomelingen van ki geḍe Mataram zullen later over alle bewoners van Java regeren. Zelfs Giri za! Mataram onderdanig zijn.

Pamanahan dankte, bood zijn kris aan, die niet werd aanvaard.

Daarop beval de priestervorst een meer te laten graven, hetgeen geschiedde. Het ontving de naam Patut. Vervolgens kregen allen verlof tot heengaan.

$\mathrm{Na}$ de terugkeer volgde de reactie op de voorspelling: in Padjang was des sultans zoon ontsteld en wilde dit vonkje (nl. Mataram) dadelijk doven, doch zijn vader wenste niet tegen God's besluiten in te gaan en vreesde het verbod van Giri te overtreden. In Mataram gaf de voorspelling $\mathrm{kj}$. geḍe aanleiding tot het uitvaardigen van een viertal voorschriften.

De Serat Kanda (508-23) biedt geen belangrijke verschillen. Het is nog uitvoeriger en schilderachtiger verteld. Ki Pamanahan neemt 100,

Het tweede luidt in de Babad Sengkala 1473 (A.D. 1551): Daha door brand verwoest; bij Raffles hetzelfde jaartal en feit met de toevoeging: disappearance of the prince... of that place; bij Hageman eenvoudig: 1554 Doho verbrand. Ook nu een sterke overeenkomst: de brand van Keḍiri, want Daha is de oude naam voor die stad.

Het derde luidt in de Babad Sengkala 1499 (A.D. 1577) de heer van Kediri verdwijnt, als alle Moslims... een kamp wordt gemaakt, het wordt omsingeld door Moslims, het wordt aangevallen door alle Moslims (onduidelijk); bij Raffles hetzelfde jaartal met: Disappearance of the Ad. of Kediri and his princess, after embracing the Mahometan religion; bij Hageman: 1579 Keḍiri Mohammedaans geworden. Ook nu weer een zekere eenstemmigheid: een gewelddadige verovering en bekering, waarbij een (heidens?) vorstenhuis te gronde gaat. 
zijn heer 1000 gewapenden mede. Deze berijdt ook een olifant. Sterk wordt er op gewezen, dat de sultan reeds in Demak door het volk aldaar tot die rang verheven werd, en dat hij dus bevestiging daarvan verzocht. Ook hier een plechtige wijding in tegenwoordigheid der Oosthoekse regenten, terwijl de sultan aan 's priestervorsten rechterhand op een alcatief gezeten was. Onder de heilmaaltijd onderscheidde de regent van Mataram zich door zijn grote netheid. De pisangbladeren voor de rijst rolde hij keurig op en hij maakte zijn plaats weer schoon, zodat het opviel. De priestervorst sprak daarop zijn voorspelling uit, waarvoor ki geḍe Mataram hem de voeten kuste.

$\mathrm{Bij}$ onderlinge vergelijking der beide voorstellingen treft ons, dat de vorst van Padjang in de oudere Serat Kanḍa oorspronkelijk revolutionairder was opgetreden, dan in de latere Babad. Hij was n.l. door het volk gekozen.

In beide verhalen blijkt duidelijk de bijna goddelijke majesteit, welke van de priestervorst uitstraalt. Wij wezen bij zijn confrater in Kudus reeds op hetzelfde verschijnsel. Dit ziet men ook in het graven van het bij name genoemde meer door de verzamelde volken. Hierdoor is het waarschijnlijk, dat deze overlevering in hoofdtrekken uit Giri stamt.

Vergelijken wij thans de geschiedenissen in Babad en Serat Kanḍa eens met Hageman.

Het verhaal bestaat uit twee gedeelten: de reis van de vorst van Padjang naar Giri, om zich te laten wijden; verder de voorspelling omtrent de Matarammer. Het eerste zal het oorspronkelijke deel zijn, het laatste een Matarams toevoegsel.

Slaat men nu Hageman op, zo bemerkt men, dat de bovenverhaalde eerste geschiedenis er wel in voorkomt, doch dat het tweede stuk (de voorspelling betreffende Mataram) ontbreekt. Dit kan natuurlijk aan een rationalistische trek bij Hageman worden toegeschreven, doch veel waarschijnlijker is, dat wij hier een oorspronkelijker lezing voor ons hebben, misschien wel uit Padjang. Dan blijkt ook, dat deze lezing een veel belangrijker staatkundige rol aan de Padjanger toekent, dan Serat Kanḍa of Babad. Immers, de bij sunan Giri verzamelde groten, volgens de laatste twee bronnen min of meer toevallig bijeen zijnde, dienen tot waardige achtergrond voor het grootse schouwspel der verheffing door sunan Giri. Bij Hageman is daarentegen de heer van Padjang veel meer het middelpunt. Zij erkennen hem, gezeten op zijn olifant, als hun heer en kiezen de reeds vermelde adipati van Sura-Baja Pandji WirjaKrama tot landvoogd.

Dit geeft ons reden te vermoeden, dat deze episode een ineenge- 
schrompeld overblijfsel is van het verhaal van een veldtocht of van een reeks van veldtochten naar Oost-Java, waartoe ook de tocht naar Giri behoorde. Deze laatste geschiedenis heeft men vooral aangehouden, omdat zij bruikbaar was, om er het tweede deel der historie aan vast te knopen: de voorspelling van de priestervorst over Mataram's grootheid.

Het geheel ander karakter van Hageman's lezing blijkt ook uit zijn mededeling, dat de opvolger van sunan Parapèn niet meer susuhunan zou heten, doch slechts panembahan, en wel op bevel van sultan Padjang!

\section{Padjang verovert Wira-Saba.}

Wanneer is de vorst van Padjang naar Giri getrokken? Twee jaartallen worden ons hiervoor opgegeven, een vroeg en een laat: 1568 en 1581 .

Het eerste danken wij aan Raffles. Het komt niet voor in zijn Chronological Table, doch in de tekst van zijn verhaal.

Sedert werd het door anderen overgenomen: door Veth (2e dr. I, 304) en daarna door Rouffaer in zijn Encyclopaedie-artikel: Padjang.

Het tweede, 1581, komt zowel in de betrouwbare Babad Sengkala, de minder betrouwbare Babad Momana als in de Babad Tanah Djawi voor.

Daar Raffles niet vermeldt, waar hij zijn wijsheid heeft opgediept, zouden wij aan de drie eenstemmige Javaanse geschriften de voorkeur willen geven.

Het jaartal 1581 komt ook het beste uit met het oog op de tochten naar de Oosthoek, die in de reis naar Giri hun einde en bekroning vonden, en met het oog op de aanwezigheid van $\mathrm{kj}$. geḍé Pamanahan (Mataram) die, naar wij onderstelden, van 1578 tot 1584 in Mataram vertoefde. ${ }^{1}$ )

Zien wij thans, of er nog uit andere bronnen aanwijzingen te halen zijn voor Padjang's veroveringen. ${ }^{2}$ )

1) Het jaartal 1581 lijkt nog betrouwbaarder, omdat het fel afsteekt tegen een achtergrond van kennelijk onjuiste jaartallen. Het wordt n.l. voorafgegaan door het jaar van kjai geḍe Pamanahan's verhuizing naar Mataram in A.J. 1532 (A.D. 1610) en gevolgd door dat van zijn dood, drie jaar later, in A.J. 1535 (A.D. 1613). Het moet dus bij een andere overlevering behoren, dan die, waarin de foute jaartallen 1610 en 1613 thuis horen, en zeer waarschijnlijk zal dit de Girische zijn. Mogelijk werd deze reeds vrij spoedig na Padjang's bedevaart opgesteld, n.l. uiterlijk in het begin der 17e eeuw.

2) Dat Padjang in de Brantas-delta conflicten gehad heeft, zou bijna de Babad Banjumas doen vermoeden, welke op de bibliotheek van het Kon. Bat. Genootschap te vinden is onder no. 526. Dr. Poerbatjaraka vervaardigde er een door 
Van Padjang's gewapend optreden, dat vele lieden van de kust zee deed kiezen, gewaagt het opstel van P. de Roo de la Faille, Uit den Palembangschen Sultanstijd (Feestbundel K.B.G. 1778-1928. II, 316).

Aan handschrift 31 van het Kon. Instituut ontleent de schrijver : „tatkala negeri Demak dialahken oléh Sultan Padjang, maka banjaklah radja $^{2}$ dan prijaji ${ }^{2}$ jang lari, maka jang masoek ka Palèmbang bernama Gedèng Soera", d.i.: toen Demak door de sultan van Padjang verslagen werd, vluchtten vele vorsten en voornamen en kwam Gedèng Soera in Palembang. Het is deze Gedèng Soera, welke bekend staat als de stichter der Palembangse dynastie, die eerst in 1821 ophield te regeren.

En in hetzelfde opstel geeft de auteur zelfs het jaartal dezer uitwijking, dat hij in een ander manuscript der genoemde bibliotheek aantrof, t.w. no. 414 : „Maka dateng priaji dari Soerabaja, bernama Kjahi Gedèng Soera, soedah didalem hidjrat Nabi 981 ia mendjadi radja Palèmbang", d.i.: Er kwam een voorname uit Sura-Baja, kj. Gedèng Sura geheten, in het jaar der uitwijking van de Profeet 981, werd hij vorst van Palembang.

De schrijver stelt dit jaar gelijk met A.D. 1603, door er eenvoudig nog eens 622 bij op te tellen, alsof het gelijksoortige eenheden waren. Met 981 zijn echter geen zonne-, doch maanjaren bedoeld en als men hiermede rekening houdt, dan komt men tot 1572 en behoeft men niet de conclusies te trekken, welke de $\mathrm{Hr}$. Roo de la Faille uit dat jaartal 1603 trekt. 1572 klopt ook veel beter, daar de onbekende schrijver van hs. 414 zijn verhaal vervolgt met het beleg van Palembang door de Bantammers, hetgeen volgens de op dit punt zeer betrouwbare Nederlandse berichten in 1596 plaats vond, dus nog vóór het onjuiste jaar 1603.

Aanleiding tot dit vergeefse beleg had een zekere pg. Mas gegeven, die zich een verwant van de sultan van Demak noemde (Sadjarah Bantěn 39). Deze avonturier had veel rondgezworven en was ten slotte door de jeugdige vorst van Bantam als leermeester aanvaard. Op diens vraag, welk land hij het eerst zou aanvallen, antwoordde pg. Mas, ,dat

mij benut uittreksel van. Hierin is n.l. sprake van de moord door de sultan van Padjang op de dipati van Wirasaba, Warga-Utama (I). Dit zou een aardige aanvulling zijn van het zeer beknopte bericht in de Babad Sengkala, welke onder A.J. 1500 (A.D. 1578) mededeelt, dat Wira-Saba verwoest werd, indien er geen Wira-Saba in Noord-Banjumas lag. 
hij in Palembang een dienaar (abdan) had, Soro geheten, die nu van hem was afvallig geworden en in lange tijd zijn huldebetoon niet was komen doen. Dien dienaar schonk hij nu aan den vorst, en hij stelde hem voor, tegen Palembang op te trekken, dat nog kapir was."

Het valt niet moeilijk, in deze abdan Soro de reeds genoemde kj. Gedèng Sura te herkennen. Daar pg. Mas zich de rechten der Demakse vorsten aanmatigde, zal hij Soro-Sura, die ook uit het eertijds aan Demak onderhorige Sura-Baja afkomstig was, daarom als zijn dienaar hebben beschouwd.

Wij kunnen dus veilig aannemen, dat $\mathrm{kj}$. Gedèng Sura, die uit SuraBaja gevlucht was voor het geweld van Padjang, in Palembang minstens van 1572 af de teugels in handen had. Het verwijt van geringe rechtgelovigheid kunnen wij ter zijde laten; dit is bijna een gemeenplaats tussen tegenstanders.

Hageman somt in het Indisch Archief (III, 28) de voorvaderen van kj. Geding-Soero op, welke zouden zijn: Djoero, Madepandan, Aria Soerabaja, Aria Pangiri, Tranggana, Patah.

Aldus zou de Palembanger uit het einde der 16e eeuw de afstammeling in het $7 \mathrm{e}$ geslacht van de eerste vorst van Demak uit het begin dier eeuw zijn, hetgeen vermoedelijk een traditionele toeschrijving is, want de tijd rijkt voor zoveel geslachten niet toe.

De voorstelling, dat de stamvader van het Palembangse vorstenhuis voor de macht van Padjang uit Java zou geweken zijn, vindt ondersteuning in een Nederlands bericht, n.l. de Instructie door Willem van Thijen, opperhoofd van Palembang voor zijn opvolger Sr. Willem Bolton dd. 22 Juni 1691 (K.A. 1388).

Eerstgenoemde verklaart hierin. dat de „Ingeseetenen van dit rijk ... afkomstig (zijn) van.... Java". Zij wonen er pas een honderd jaar. In de 16 e eeuw rezen n.l. twisten tussen de zonen van de overleden ,opperregent" op Java, die zich zo uitbreidden, dat de eerste of oudste zoon zich de titel van Susuhunan of Keizer aanmatigde en zijn jongere broeders van hun gebied beroofde.

Hierin herkent men een korte samenvatting der gebeurtenissen op Java in de $2 \mathrm{e}$ helft der $16 \mathrm{e}$ eeuw. De opperregent, wiens zonen aan het twisten sloegen, is ongetwijfeld een herinnering aan de $3 \mathrm{e}$ vorst van Demak, sultan Trenggana. De eerste of oudste zoon, die zich de titel van sunan of keizer aanmatigt, moet stellig Sénapati verbeelden, ook al heette diens kleinzoon pas echt sunan. Toch kan de stichter van Palembang's dynastie niet door deze Matarammer verdreven zijn. Daar- 
toe bleken in later dagen de banden tussen Mataram en Palembang te hecht. Het verzwegen Padjang moet de schuldige zijn.

Van Thijen vervolgt: Een der jongere broeders van de usurpator maakte zich een grote aanhang, doch nam desniettegenstaande de vlucht ter zee met vrouw en kind. Zo zette hij zich dan in het tegenwoordige Palembang ter neder, hetwelk toen nog aan de zee lag. Sedert nam hun aantal sterk toe, niet slechts dank zij de polygamie, doch ook, doordat zij alle ontevredenen en vluchtelingen uit andere oorden met open armen ontvingen. Toch bleven zij zich tot 1691 nog als Javanen kleden en voelen.

Het Nederlandse bericht steunt dus de overlevering omtrent de vlucht over zee der stichters van de Palembangse dynastie, bevreesd als zij waren voor het geweld van Padjang.

De geschiedenis van Palembang wijst er dus op, dat Padjang's heerschappij in Oost-Java niet zonder ernstige schokken is tot stand gekomen.

\section{Padjang's hoogtepunt.}

De Engelse zeevaarder Francis Drake, die in 1580 Java aandeed, doch niet veel verder kwam dan Balambangan, deelt echter mede, dat gans Java onder een aantal vorsten verdeeld was, doch ,dat die allen aan éénen vorst het oppergezag toekenden". (Veth² I, 317).

Voor deze vorst komt Sénapati nog niet in aanmerking; daartoe is het te vroeg. Het moet dus wel de vorst van Padjang zijn, die zich in 1580 van het oppergezag, met name van dat over Oost-Java, had meester gemaakt.

Kent Drake zelfs de naam van de hoofdstad van dit rijk niet, deze is wel bekend aan de Portugese Diego de Couto, die het werk van de Barros, Da Asia voortzette.

In zijn 4e decade, 3e boek beschrijft hij de tocht van Francisco de Sá naar Java (1528) en benut deze gelegenheid, om over Java iets uitvoeriger te zijn. Dat hij hierbij niet het Java van 1528 voor ogen heeft, doch dat van veel later tijd, blijkt wel uit het vervolg.

Aan de Noordkust merkt hij verschillende heersers op, van welken enigen aan de anderen onderworpen zijn (huns sujetos aos outros). Hij begint ze van het Oosten af op te sommen: Valle (Bali?), Paneruca (Panarukan), Agasai (Gresik), Sodayo (Sidaju).... Tubão (Tuban), Berodão (Brondong), Cajoão (Djuana), Japará.... Damo (Demak), Margão (Samarang), Banta (Bantěn), Sunda (Padjadjaran ?), Andreguir (Indragiri, op Sumatra?). 
Wij sloegen opzettelijk over: Panião (Padjang), daar dit geen kustplaats is, waarvan De Couto verhaalt: „cujo Rey reside pelo sertão trinta leguas e he como Emperador destes, e de outros adiante." (= welks Koning ongeveer 30 mijlen of 185 K.M. in het binnenland woont en van de reeds genoemde en die nog te noemen zijn, Keizer is).

Een nauwkeurige lijst kan die van De Couto niet wezen, al was het alleen, omdat Bantam toch wel nooit onder Padjang gestaan heeft, om maar te zwijgen van Indragiri op Sumatra, terwijl belangrijke plaatsen als Sura-Baja en Tjerebon niet eens genoemd worden. Djuana is nimmer een zelfstandig vorstendom geweest, doch was steeds de voorhaven van Pați, dat ontbreekt. Met deze correcties lijkt deze lijst der voornaamste strandrijkjes tamelijk volledig. Men vergete niet, dat de Portugezen in Malakka, van welke De Couto zijn inlichtingen had, vermoedelijk niet al te best over Java, dat nog honderden mijlen ver weg lag, voorgelicht konden zijn.

Toch wekt De Couto's lijst wel de indruk, dat op een gegeven ogenblik het grootste deel van Java aan Padjang gehoorzaamde, al was deze gehoorzaamheid niet strikt. Dit wordt wel duidelijk aangetoond door het eigenmachtig optreden der koningin van Djapara nog in 1574. Maar ook in Demak was nog iets van een zekere zelfstandigheid bewaard gebleven.

Dit bleek duidelijk in 1564. (De Couto, Da Asia VIII, xxI). Toen poogde de sultan van Atjeh „o Rey de Dama Imperador de Jaoa" (koning van Demak, keizer van Java) door gezanten over te halen tot een grote tocht tegen Malakka. De koning van Demak weigerde echter, daar hij vreesde, dat, als de vorst van Atjeh, „hun Tyranno insaciabel” (een onverzadigbare tyran), heer van Malakka werd, zijn rijk er ook aan zou gaan. Derhalve sloeg hij niet enkel het voorstel af, doch liet zelfs zijn gezanten doden.

Dit wonderlijk verhaal bewijst, dat men in 1564 te Malakka de stad Demak nog als de zetel van het Javaanse oppergezag beschouwde, ten rechte of ten onrechte. De aanwezigheid van telgen uit het oude vorstengeslacht aldaar kan geredelijk tot deze opvatting aanleiding hebben gegeven. Wie weet wat deze heren, ofschoon feitelijk vazallen van Padjang, tegen het buitenland hebben beweerd over hun schijnmacht!

Overigens lijkt het nog zeer de vraag, of zij het zouden gewaagd hebben de Atjehse gezanten zo hardnekkig te behandelen. Gezien zowel vanuit politiek als panislamietisch standpunt lijkt het een dwaze daad, de Atjeher dusdanig te tergen. Moet deze gewelddaad niet eerder op rekening gesteld worden van de vorst van Padjang, de ware heerser 
over Java, die bovendien zijn sporen in de interinsulaire politiek nog moest verdienen? Doch de schimmige vorst van Demak, de keizer van Java in naam, werd er voor aangezien.

$\mathrm{Na}$ Padjang's val zou Demak heel even een kortstondige herleving doormaken om vervolgens tot de betekenis terug te vallen, die het $n u$ nog bezit, n.l. als de plaats met de allerheiligste moskee van Java. ${ }^{1}$ )

1) Het bericht uit Lodewycksz' Eerste Boeck van 1598 over de Eerste Schipvaert der Nederlanders naar Oost-Indië, dat spreekt over Demak, „waer den Keyser noch voor Coninck gekent wordt", is door G. P. Rouffaer in zijn Encyclopaedie-artikel: Padjang, niet juist verstaan. Wij komen hierop terug. 


\section{EERSTE DRIE JAREN VAN SÉNAPATI.}

Sénapati's aanstelling.

Over het sterven van kj. gẹ̣é Mataram is de Babad (72) zeer kort:

$\mathrm{Na}$ de vermelding van de Mataramse welvaart - voedsel en kleding waren goedkoop - volgt die van $\mathrm{kj}$. gedé Mataram's ziekte. Hij droeg de zorg voor zijn kroost aan kj. Djuru-Martani over, wie ook zijn kinderen moesten gehoorzamen. Zijn zoon, ng. Lor-ing-Pasar zou zijn opvolger worden. Het lijk werd ten Westen der moskee begraven.

De Serat Kanḍa (527-28) geeft niets meer.

Daarop volgt de aanstelling van zijn zoon, Babad 72-73:

De dag na het overlijden trok kj. Djuru-Martani met de ganse familie naar Padjang om voor de sultan te verschijnen, juist op een Maandag. Ze namen plaats onder de waringin kurung. Door de sultan opontboden, meldde kj. Djuru-Martani de dood van hun heer en vroeg, wie der 5 zonen de petinggi van Mataram zou opvolgen. De sultan wees zijn „zoon” ng. Lor-ing-Pasar aan en noemde hem: Sénapati-ing-Alaga Sajidin Panatagama. Het 1e jaar behoefde hij niet ten hove te verschijnen, maar mocht zijn land in orde brengen en genieten.

Daarop kusten $\mathrm{kj}$. Djuru en zijn neef des sultans voeten en vroegen verlof, om heen te mogen gaan.

Sedert groeide het aantal inwoners van Mataram en Sénapati leidde een onbezorgd leven.

Ook hier levert de Serat Kanḍa (528-31) weinig verschillen op, waarvan nog de belangrijkste zijn, dat niet slechts het nieuwe hoofd van Mataram een nieuwe naam krijgt, doch ook zijn oom, n.l. ad. Mandaraka (in de Babad pas veel later p. 102). Van de aanstelling verleent de sultan een piagem, gelijk aan zijn vader, terwijl tg. Majang en nòg een ngabéhi Sénapati zullen installeren.

Alles gaat dus heel gewoon en regelmatig. Sénapati wordt in volle vrede geheel naar behoren aangesteld. De Matarammers gedragen zich zeer nederig, verschijnen op de hofdag (Maandag), nemen plaats onder 
de boom der smekelingen, laten het aan de sultan over, wie der vijf de „petinggi van Mataram" (geen daverende titel) zal opvolgen. Tot loon verkrijgt hij in de Babad een titelnaam, veel schitterender, dan hij ooit heeft gedragen en kennelijk onhistorisch. De piagem en de installatiecommissie komen slechts in de Serat Kanḍa voor. De jaarlijkse plicht om ten hove te verschijnen namen de latere vorsten zeer hoog en maten er de getrouwheid hunner vazallen mede af.

\section{Sénapati blijft regeg.}

Zien wij thans, wat de Babad (73-74) ons over de eerste daden van Sénapati weet te verhalen:

Het eerste jaar, dat Sénapati niet ten hove behoefde te gaan, misbruikte hij, om zijn Matarammers stenen te laten bakken voor een ringmuur. Dit verleende hem blijkbaar moed, om ook het tweede jaar thuis te blijven. Zijn oom, die hem daarover de les las, werd met een kluitje in het riet gestuurd.

De sultan, in pracht en praal gezeten, kwam dit ter oren, en hij stuurde er 2 metgezellen uit zijn jeugd op af : de ngabéhi's Wuragil en Wila-Marta.

Sénapati ontving beiden niet eens aan huis, doch op een wandelrit naar het Zuiden, in Lipura. Hij steeg zelfs niet af, zij daarentegen wel. Nederig brachten zij hun drievoudig verzoek te berde: $1^{\circ}$ Sénapati moest niet meer zo vaak gastmalen houden; $2^{\circ}$ diende zijn haar te laten afscheren; $3^{\circ}$ zijn opwachting in Padjang maken.

Het antwoord van de Matarammer was hooghartig: $1^{\circ}$ eten en drinken kon hij niet laten, want hij had nog trek; $2^{\circ}$ zijn hoofdhaar kon hij niet laten afscheren, want het groeide toch weer aan; $3^{\circ}$ hij zou pas in Padjang komen, als de sultan ophield 2 zusters tot echtgenoten te nemen, zo mede de vrouwen en dochters zijner onderdanen op te eisen.

De gezanten vonden dit antwoord zo bar, dat ze het niet aan hun vorst dorsten mede te delen, doch een ander bedachten. Sénapati zou dan gezegd hebben: „Tot uw dienst” en hun aangeraden hebben, maar eerder huiswaarts te gaan, want: „Uw zoon zal spoedig volgen". Hierop zweeg de brave sultan.

De Serat Kanḍa (532-35) vertoont belangrijke verschillen:

De gezanten zijn de tumenggungs Wira-Merta en Merta-Nagara. De muurbouw blijft onvermeld, evenals Sénapati's onbeschaamd te paard zitten, terwijl de gezanten afstijgen. Hun vermaning betreft slechts Sénapati's vrolijk leven en partijen geven. Zijn antwoord is niet minder brutaal dan in de Babad: hij wil aan het verzoek voldoen, mits hij, als de troon ledig en 's vorsten zoon niet in aanmerking komt, dan mag 
opvolgen. Bij gelegenheid zal hij wel eens in Padjang verschijnen. Ook hier wordt het antwoord voor de sultan verzacht. Het geven der partijen gaat daarna gewoon door.

Het eerste bezwaar in de Babad en het enige in de Serat Kanḍa is het houden der maaltijden. Hiermede zijn ongetwijfeld politieke maaltijden bedoeld, waarop Sénapati zijn aanhangers aan zich poogt te binden door hen te onthalen en in een vrolijke stemming te brengen. Wij komen hierop terug (p. 73).

Het tweede bezwaar in de Babad is zijn slecht gedrag als Moslim. $\mathrm{Hij}$ zal zijn godsdienstig leven dienen te beteren, waarvan het afscheren van het hoofdhaar een zichtbaar teken is.

Het derde bezwaar van de Babad betreft de eigenlijke aanleiding tot de komst der gezanten: Sénapati's wegblijven van de jaarlijkse huldiging, stellig een zeer ernstig vergrijp.

Sénapati's brutaal antwoord in de Babad slaat op des sultans wulpse aard, waarop reeds eerder werd gezinspeeld (p. 32).

Merkwaardig is, dat bij deze gelegenheid geen bezwaar wordt geopperd tegen het stenen bakken, dat de Babad vermeldt. Het ontbreekt ook in de Serat Kanḍa en zal er dus oorspronkelijk wel niet geweest zijn.

De rang der gezanten is nog niet de allerhoogste, in de Babad: ngabéhi, in de Serat Kanḍa: tumenggung. De latere zullen hen overtreffen.

Het onheuse antwoord van Sénapati bevat in de Babad een tegenbeschuldiging, in de Serat Kanḍa onthult het Sénapati's eerzuchtige bedoelingen: vorst worden! Doch welke de verschillen ook mogen zijn, in ieder geval is Sénapati's antwoord ongeschikt voor het oor van de sultan en wordt dus verzacht.

Sénapati wint aanhangers.

De Babad (74-76) vervolgt nu met een zeer afwijkend stuk:

Sénapati moest na het vertrek der 2 gezanten een preek aanhoren van zijn wijze oom ki Djuru-Martani, welke hem zijn onbesuisdheid voor de voeten wierp. Bovenal wees hij hem op zijn drievoudige schuld tegenover de sultan als heer, vader en leermeester. Een strijd tegen hem ware eerder laf dan moedig te noemen.

Dit maakte wel indruk en Sénapati vroeg zijn oom om raad, hoe zijn idealen te bereiken: de heerschappij over Java voor zich en zijn nazaten.

Ki Djuru ried hem, zich smekend tot Allah te wenden, opdat 
de vorst hem blijve liefhebben en goedkeure, dat hij zijn opvolger werd.

Daarop bad Sénapati dag en nacht tot Allah.

De Serat Kanḍa (537-38) heeft een wat zwakkere verzoeningstendens tussen Sénapati en de sultan. De Babad verafschuwt schokken en streeft er naar, Sénapati minder revolutionair te maken, dan hij was.

Van Sénapati's bidden tot Allah is zijn tapa moeilijk gescheiden te denken. Mogelijk is dit bidden beter weer te geven door : zijn gedachten concentreren, en wel met een bepaald doel, in dit geval de verwerving der opperheerschappij.

Daarop volgt in de Babad (76-78) een stuk, ontbrekende in de Serat Kanḍa, dat wij kunnen zien als een bredere uitwerking van een deel der bovenstaande episode, n.l. die der politieke maaltijden:

De mantri's pamadjegan uit Keḍu en Pagelèn waren op weg naar Padjang, om hun pacht af te dragen. Sénapati onthaalde hen heerlijk. Vrouwenbediening ontbrak niet: dansen, zalven met boréh, zelfs het steken ener bloem achter het oor.

Spontaan beloofden deze braven hun weldoener trouw tegen zijn vijanden, welke ook, desnoods met storting van hun bloed.

Sénapati, verrast over dit resultaat, erkende thans een middel te hebben verworven, om met God's hulp de macht in Padjang te veroveren en hij begiftigde de mantri's met mooie kleren.

Daardoor steeg hun geestdrift ten top. Onder handgeklap beloofden ze hun pacht maar aan Sénapati af te dragen, ,,want dat is volkomen hetzelfde; niet alleen in Padjang is een vorst, maar ook in Mataram!"

Sénapati antwoordde dubbelzinnig. Samen zouden zij hun opwachting maken in Padjang, d.w.z. later. Tegen des sultans toorn zou hij hen beschutten, ,want de sultan heeft al zijn verwachtingen op mij gesteld". Verlangde iemand een hogere rang, zo was hij door Z.H. gemachtigd, die te verlenen.

Deze laatste mededeling bracht de mantri's tot razernij. „Ze waren van mening, dat ze Sénapati als vorst moesten erkennen." $\mathrm{Ze}$ voerden krijgsdansen uit en vertoonden hun bovennatuurlijke kracht en onkwetsbaarheid, door omhoog geworpen speren of stenen met hun lichaam op te vangen.

Sénapati, door zijn concentratie op Allah krachtig geworden, blijkt tot bijzondere dingen in staat. In dit stuk komt zijn talent tot bezielen, naast zijn geslepenheid om er partij van te trekken, om het zeerst tot uiting. Intussen is het een feit, dat de Matarammers op den duur op zeer goede voet zijn geraakt met de bevolking van Keḍu en Pagelèn. Deze westelijke mantjanagara heeft hun nimmer die moeilijkheden bezorgd, welke Oost-Java opleverde. 
Een plotselinge dissonant verstoorde evenwel de harmonie (Babad 77-78):

Onder de geestdriftige mantri's bleef er een nuchter, ki Botjor. Hij weigerde zich onder Sénapati te scharen en wou eerder diens onkwetsbaarheid met zijn vlijmscherpe kris Kebo-Dengen op de proef stellen. Sénapati had hem echter in de gaten en liet zich 's nachts aan tafel rustig door ki Botjor in de rug steken, tot deze uitgeput ter aarde zeeg en hem de voetkus bracht. Omziende, vergaf hem Sénapati. De kris stak in de grond, toen ki Botjor heenging.

Deze laatste episode besprak dr. Pigeaud in zijn opstel: Alexander, Sakèndèr en Sénapati (Djawa VII 1927, p. 321-61), en deelde het volgende mede:

De Botjor-episode is n.l. niet slechts bekend uit de Babad Tanah Djawi, doch ook uit de Babad Padjadjaran en de Serat Baron Sakèndèr. Geen dezer drie boeken meldt echter iets over de herkomst van de heer van Botjor. De Babad Pasir (Verh. Bat. Gen. LI, 1e stuk) geeft echter enige aanwijzingen.

Het landschap Botjor wordt daar genoemd onder de Oostelijke onderhorigheden van Pasir (in Banju-Mas) in de oude tijd vóór de Islam. Deze gebieden worden voorgesteld als de landen der schoonzoons van ad. Kanḍadaha van Pasir, vermoedelijk een mythische vorst. Te Botjor vestigde zich in later tijd pg. Tolé, de zoon van pg. Sénapati I, welke de eerste Moslimse vorst van Pasir was, tevens de trouwe vazal en krijgsoverste van de eerste sultan van Demak. Pg. Tolé viel echter weer van Demak en de Islam af en werd daarom uit Pasir verdreven door de krijgsmacht van de tweede sultan van Demak, nadat hij door zijn oom, tevens patih Wira-Kantjana aan zijn vijanden was verraden. Deze volgde hem toen in Pasir op als pg. Sénapati II.

Men kan daarom ki Botjor wellicht beschouwen als een afstammeling van deze pg. Tolé. Mogelijk, dat het bewustzijn zelf van oude afkomst te zijn, deze heer van Botjor belet heeft, zich aan de heer van het pas ontloken Mataram te onderwerpen, welke hij als „wong tjilik" verachtte. Ook was diens titelnaam dezelfde, als die de eerste Moslimse vorst van Pasir waarschijnlijk van de Demakse sultan verworven had. $\mathrm{Ki}$ Botjor moest zich dus minstens de gelijke van Sénapati Mataram achten en slechts een doorslaand bewijs van bovenmenselijke kracht en onkwetsbaarheid kon hem overtuigen van diens grootse roeping, heer over gans Java te worden.

Bovengenoemde bijzonderheden maken het inderdaad waarschijnlijk, 
dat Sénapati bij het winnen der groten aan de Westzijde van zijn gebied, toch wel op énige tegenstand gestuit is.

\section{Sénapati ondergaat wïjdingen.}

$\mathrm{Na}$ de ki Botjor-episode volgt het Lipura-verhaal, dat behalve in de Babad, ook in de Serat Kanḍa voorkomt. De Babad (78-79) verhaalt:

Sénapati vertrok met 5 man naar Lipura, waar een steen, mooi van kleur lag. Daarop legde hij zich te slapen. Ki Djuru (Martani) ging zijn neef achterop en trof hem slapende op de glanzende steen. Hij wekte hem met de woorden: „Jongen, sta op. Je zegt, dat je vorst wil worden, en je ligt daar maar lekker te slapen."

Toen viel er een ster van de hemel, zo groot als een klapper, glanzende als de maan. Sénapati ontwaakte en sprak hem toe.

De ster antwoordende, voorspelde de verhoring van zijn gebed. Zelfs zijn achterkleinzoon zou nog vorst te Mataram zijn, doch dan zou het rijk onder vele natuurverschijnselen uiteen vallen.

Deze profetie vervulde Sénapati met stoute gedachten, waarvoor hij door zijn oom berispt werd. Samen besloten ze daarop tot Allah te smeken. „Kom, laten we het werk verdelen: jij gaat naar de Zuidzee en ik beklim de Merapi, en beiden trachten we Allah's wil te leren kennen...."

De Serat Kanḍa (540 -42) vertoont onbeduidende verschillen:

In Lipura is Sénapati's lustplaats. Boven het hoofd van zijn neef ziet zijn oom een licht zo groot als een klappernoot, dat dadelijk weer verdwijnt. Sénapati vertelt daarop zijn droom: hij zag een ster nederdalen en hield het rijk Java als een klomp aarde in de hand. Deze verschijningen leveren dan verschillend commentaar op. Oom zegt in ieder geval, dat het niets te beduiden heeft.

Dergelijke verschijningen passen bij iemand, die een grootse toekomst tegemoet gaat. Reeds bij Djaka-Tingkir valt een maan op deze neer (Babad 37), terwijl het bij sunan Mangku-Rat II zeven manen zijn, welke diens borst binnendringen (Babad 180).

Wat Lipura betreft, dit wordt reeds eerder vermeld (Babad 73) en het zal later als ballingsoord voor Mangku-Rat II dienst doen (ibid. 159). Het zal wel gelijk zijn met Nglipura, 4 paal ten Z.W. van de Jogjase kraton, waar heden ten dage nog een steen vereerd en door een djuru-kuntji bewaakt wordt (Pigeaud 355).

Met de achterkleinzoon, onder wie het rijk zou uiteen vallen, wordt sunan Mangku-Rat I bedoeld, die de val van zijn kraton in 1677 nog 
zou overleven. Deze bijzonderheid mist de Serat Kanḍa, wat weer in de richting van diens grotere oorspronkelijkheid wijst.

Ons doet eigenaardig aan, dat de aanbidding van Allah geschiedt in de aardse vormen van berg- en zee-verering, overigens vermoedelijk een oeroud gebruik in Midden-Java ten Zuiden.

De Babad is, als vaker, veel meer uitgewerkt dan de Serat Kanḍa. Dit treft ons eveneens bij het volgende tafreel: Sénapati's bezoek aan de godin van de Zuidzee (p. 79-82):

Terwijl kj. Djuru zich naar de Merapi begaf, vertrok Sénapati Oostwaarts en liet zich de kali Oempak afdrijven. Aan de mond had hij een ontmoeting met de olor-vis Tunggul-Wulung, wie hij eens barmhartigheid had bewezen, en die hem nu zijn rug ter zitplaats bood. Sénapati bedankte, ging aan land, en bad staande tot Allah. Gevolg: een hevige storm, die bomen ontwortelde en de vissen op het droge wierp, terwijl het water zo heet was, alsof het kookte.

Deze natuurverschijnselen trokken de aandacht der rara Kidul, die naar buiten kwam en de biddende Sénapati ontwaarde. Zij raadde zijn gedachten. Daarop naderde ze, bracht hem de sembah en voorspelde zijn schone toekomt. Alle geesten van Java zouden hem dienen. Daarop kalmeerde Sénapati, en de rust in de natuur keerde terug, de gestorven vissen herleefden.

Daarna begaf zich Sénapati met de vorstin naar het onderzeese paleis, waar zij elkaar 3 dagen en nachten liefkoosden en hij onderricht kreeg in de staatkunde, bijzonder in de kunst, om de genoemde geesten op te roepen.

Ook thans is de Serat Kanḍa (541-43) alleen iets eenvoudiger. Het vissenverhaal ontbreekt. Het hof der vorstin heet naar de grot guwa Langsé, thans nog vermaard, omdat de sunan daar bezoeken placht af te leggen (zie mijn: De reis van Mangku-Rat IV naar Mataram TBG LXXXIII 1949, 354).

In beide verhalen zien wij duidelijk, tot welke grote daden de tapa Sénapati in staat stelt : een afdaling in zee. Wat kj. Djuru-Martani op de Merapi beleefde, wordt ons onthouden.

Daarop volgt de bouw van de ringmuur, Babad $82-83$ :

Sénapati keerde uit het paleis der ratu terug, over het water lopende. Te Parang-Tritis trof hij sunan Kali-Djaga, zittende onder een druipsteenrots, verdiept in godsdienstige overpeinzingen. Sénapati kreeg al dadelijk van hem de vermaning, niet te zeer op zijn sekti te vertrouwen, niet te hoogmoedig te worden enz. „Kom, we gaan naar Mataram, ik wil je woning zien.” 
In Mataram zag de heilige, dat Sénapati's woning nog onbemuurd was, hetgeen hij als overmoed brandmerkte. Hij moest dus zijn woning van een ringmuur voorzien, de pager bumi. Elke droge moeson dienden de Matarammers stenen te bakken. Als hij er genoeg had, kon hij een stad met een gemengde bevolking bouwen. Met een klapperdop water sprenkelende, gaf hij de loop van de ringmuur onder gebedengeprevel aan. Daarop volgden afscheid en vertrek van de heilige man.

De Serat Kanda (544 -47) levert een belangrijk verschil op. Niet sunan Kali-Djaga treedt op, doch slechts zijn eerder (505) vermelde zoon, sunan Adi (de uitstekende). Sunan Kali-Djaga is volgens de Serat Kanḍa niet bezuiden het Kenḍeng-gebergte geweest, wat m.i. de oorspronkelijke bedoeling ook geweest is.

Bovendien is er een invoegsel: hoe Sénapati de panakawan DjuruTaman, „blank van kleur” verwierf. Een Europeaan? Wij komen er op terug (p. 87).

Verder is alles veel eenvoudiger, in het bijzonder de preken van de heilige man.

Wat de muurbouw betreft, bezoekers in de 17e eeuw, o.a. Rijklof van Goens (312-313), viel de aanwezigheid van aanzienlijke oude muren in Mataram op. Een oudheidkundig onderzoek daarnaar zou ongetwijfeld belangrijke resultaten opleveren, doch heeft nog niet plaats gevonden. Dat Sénapati zijn volk elke droge moeson aan het stenen bakken kan zetten, bewijst wel, dat hij er voldoende de wind onder heeft. Stellig was een muur in het onbeschaafde Zuiden toenmaals iets betrekkelijk nieuws. Geen wonder dan ook, dat de heilige van het Noorden met gewijd water het bestek moet aangeven. Aan de kust had menige stad wallen en torens, in het binnenland feitelijk gene.

\section{Het tweede Padjangse gezantschap.}

$\mathrm{Na}$ deze muurbouw, volgt in de Babad (83-85) het tweede Padjangse gezantschap, dat minder vlot verloopt dan het eerste:

Het gerucht van Sénapati's overmoed bereikte intussen Padjang. Op een hofdag beval de sultan zijn zoon pg. Benarwa, zijn schoonzoon de ad. Tuban en de patih, tg. Mantja-Nagara, opheldering te vragen. De mantri pangalasan (= dienaar), bevriend met Sénapati, waarschuwde hem tijdig, zodat hij de ontvangst goed kon voorbereiden.

Te Randu-Lawang ontmoette Sénapati zijn „broeder”. Hij steeg van zijn paard en zij omhelsden elkander, wenende. Sénapati beantwoordde Benawa's vragen naar zijn gedrag ontwijkend. $\mathrm{Na}$ een onthaal zetten zij de reis op de rug van een olifant voort. Ook 
thuis was het onthaal luisterrijk. De gamelan Gala-Gandjur speelde. Buiten werd het gemene volk getracteerd. Benawa twijfelde niet meer aan Sénapati's onschuld.

Ad. Tuban, die tot dusverre gezwegen had, kwam op de gedachte hun lieden krijgsdansen te laten uitvoeren. Ook Sénapati's onhandelbare zoon, rd. Rangga, deed mee. Zijn speer en schild werden elk door 4 man getorst, doch hij wierp ze tot ontzetting van ad. Tuban omhoog. Deze liet zijn ondergeschikten rd. Rangga aanvallen, om diens onkwetsbaarheid te beproeven, doch men kon hem niet wonden. Toen hij zich mocht weren, sloeg zijn vuist een Tubanner de hersens in, wat grote opschudding baarde. Pg. Benawa en ad. Tuban vertrokken daarop zonder afscheid.

In Padjang legden zij tegenstrijdige verklaringen af. De sultan vond beide even juist. Tg. Mantja-Nagara en ad. Tuban vergeleken daarop Mataram met de bekende vonk, maar de sultan verklaarde niets tegen Allah's raadsbesluit te vermogen.

De Serat Kanḍa (548-56) vertoont enige afwijkingen:

Klagers over Sénapati's muurbouw en voorgenomen afval zijn de schoonzonen van de sultan, de hoofden van Tuban en Demak: Sénapati was nu al in 3 jaren niet ten hove geweest en had de verplichte geschenken niet opgebracht. De twee genoemde tumenggungs worden met pg. Benawa en 1000 krijgslieden naar Mataram gezonden. Van Prambanan uit sturen zij een boze brief.

Sénapati vertrekt daarop ook met zijn familie en 1000 man naar Randu-Gunting, waar de nodige afdaken gereed gemaakt zijn. De begroeting is evenals de opmars naar Mataram gelijk aan die in de Babad, behalve dat de twee stoeten in twee rijen achter hun meesters aanlopen. Een gesprek met Benawa heeft op de rug van de olifant plaats. In Mataram wordt 3 dagen feest gevierd, waarop de krijgsdans van twee Tubanners volgt. Hieraan doet ook de 17-jarige rd. Rangga mede, met het gevolg, dat beiden overlijden. Het omhoog geworpen schild van rd. Rangga treft bijna ad. Tuban, zodat deze schrikt en zonder afscheid vertrekt. Ten slotte het dubbele verslag aan de sultan, wiens berustend oordeel hier ontbreekt.

Groot zijn de verschillen dus niet. In plaats van tg. Mantja-Nagara, patih treedt in de Serat Kanḍa de tg. Demak, een spruit uit het oude vorstenhuis. In ieder geval zijn het voornamere personen dan de eerste keer en, hetgeen niet zonder betekenis lijkt, het zijn lieden benoorden de bergen, uit de kuststreek. Zowel tg. Demak als tg. Tuban zullen eens met Sénapati de degen kruisen. Beduidt hun zending een bijzonder grote invloed der strandgebieden in Padjang, bevorderd door een verouderende en aftakelende vorst? 
Niet zonder geestigheid wordt beschreven, hoe het aanvankelijk gunstig verloop der netelige conferentie, dank zij Sénapati's wilde zoon rd. Rangga toch nog op een botsing uitloopt.

De gamelan Gala-Gandjur zocht ik te vergeefs in Kunst's Toonkunst van Java. Over rd. Rangga's einde, zie Babad 100-101.

\section{Samenvatting der eerste drie jaren.}

Pogen wij dit hoofdstuk thans te overzien en samen te vatten:

$1^{\circ}$ Sénapati's overmoed, blijkende uit het wegblijven van het hof en het werven van aanhang (de mantri's pamadjegan);

$2^{\circ}$ zijn wijdingen in Lipura en bij rara Kidul;

$3^{\circ}$ het matigende optreden van zijn oom $\mathrm{kj}$. Djuru-Martani en sunan Kali-Djaga (of diens zoon sunan Adi);

$4^{\circ}$ de twee Padjangse gezantschappen en de breuk met de sultan.

Over het algemeen zijn deze feiten niet te controleren door gegevens uit andere bronnen, doch zij liggen wel in de lijn van het verhaal. Evenwel treft ons sterk, dat vooral in de Babad het optreden der vermaners wel belangrijk aan omvang en betekenis heeft gewonnen, zulks in tegenstelling met de deels roekeloze, deels gewetenloze daden van Sénapati, die er mede afwisselen. Niet minder dan drie preken telt de Babad, twee van kj. Djuru-Martani, één van sunan Kali-Djaga, en vnl. zijn zij gericht tegen Sénapati's overmoed. Daartegen helpen slechts nederige smeekbeden tot Allah, dag en nacht, die voorzeker tot hetzelfde gewenste doel zullen leiden. Jammer, dat deze ogenblikken van inkeer slechts kort duren en afgebroken worden door nieuwe euveldaden. Sunan Kali-Djaga's laatste vermaning verloochent deze trouwens zelve, door Sénapati te raden zijn huis te ommuren, onder de huichelachtige bewering dat juist het weglaten van zo'n muur hoogmoed zou verraden (Babad 82).

Het kan moeilijk anders, of deze preken en vermaningen zijn in later tijd sterk in omvang toegenomen. De lectuur van Sénapati's heldendaden moet wel voor jeugdige pangérans, die eerzuchtige plannen koesterden, bedenkelijk geweest zijn. Daarom hebben de eindredacteuren van Sénapati's jeugdgeschiedenis voorzorgen getroffen, om de schadelijke werking door de versterking van het stichtelijke element te beletten. Dit element neemt echter, nadat Sénapati vorst geworden is, in omvang en betekenis af. Dan is overmoed geen zonde meer.

Het optreden van opstandige prinsen in de loop der 18e eeuw zal het opnemen dezer opbouwende toespraken bevorderd hebben. 


\title{
SÉNAPATI VEROVERT DE KRATON VAN PADJANG.
}

\author{
De aanleiding tot de oorlog.
}

$\mathrm{Na}$ het verhaal van het tweede mislukte Padjangse gezantschap komt de aanleiding tot de oorlog tussen Mataram en Padjang ter sprake. Deze wordt in de Babad (86-90) uitvoerig en anecdotisch verhaald:

In Padjang woonde Sénapati's zwager, tg. Majang. Diens zoon, rd. Pabélan, was knap van uiterlijk, doch een vrouwenverleider en huichelaar. Van trouwen had hij een afkeer. Zijn vader, ten einde raad, besloot hem er in te laten lopen en ried hem, geen vrijerij te beginnen met de dochters van Jan en alleman, doch met des sultans dochter, ratu Sekar-Kadaton. Aan het bezwaar, dat de schone zorguuldig in de binnen-kraton werd bewaard, kwam vaderlief te gemoet, door de zending van geurige tjempakabloemen te adviseren, die in staat zijn, om elke vrouw in verwarring te brengen.

Aan een dienares der prinses, Soka geheten, die de pasar bezocht, stelde rd. Pabélan onbeschaand een pakje droge, geurige bloemen met ingestoken minnebrief ter hand. Het resultaat was een uitnodiging tot een nachtelijk bezoek : „Radèn, je wordt vanavond door H.H. verwacht en ze houdt een maaltijd en kleren klaar."

Rd. Pabélan riep de hulp van zijn vader in, om ongemerkt binnen te komen. Deze vergezelde hem tot aan de muur, wreef er tegen onder gemurmel van toverspreuken, en inderdaad zakte de ringmuur even in, om de jongeling toegang te verlenen, rees daarna weer omhoog. Bij zijn vertrek poogde Pabélan vergeefs de muur weer te doen zakken. $Z$ ijn vader had hem de spreuk verkeerd geleerd. Hij besloot nu het beste ervan te maken, wat ervan te maken viel, en vermaakte zich 7 dagen en 7 nachten met de prinses.

Haar talrijk gevolg, opmerkzaam geworden door haar lange afwezigheid, kreeg in de gaten, wat er aan de hand was, en waarschuwde Z.H. Deze stuurde 2 aanvoerders der tamtama's: WiraKerti en Sura-Tanu, met 22 man. De eerste wist Pabélan door bedriegelijke toezeggingen naar buiten te lokken, waar hij snel door de tamtama's werd neergestoken. Zijn lijk wierp men in de Lawijan-rivier.

De toorn van de sultan strekte zich echter ook uit tot de vader van de schuldige jongeling. Ki Majang werd daarom naar Sama- 
rang verbannen, waarheen hem 80 Padjangse mantri's met 1000 koppen zouden begeleiden. Tg. Majang's vrouw zond echter ijlings een bode aan haar broeder Sénapati, ter inlichting.

Sénapati werd toen heel boos en sprak tot de mantri's pamadjegan: „Mijn vrienden de pachters, ik vraag jelui hulp. Mijn zwager.... is dezer dagen naar Semarang verbannen. Tracht hem in handen te krijgen, waar.... ook.... Gaat maar over Kedu.."

Snel wierpen zij zich in het zadel en haalden in galop het Padjangse convooi te Djati-Djadjar (bij Ungaran) in. Woedend vielen ze er met hun pieken op aan. De Padjangers werden gedood, gewond of verjaagd. $\mathrm{Ki}$ tg. Majang werd verlost en meegenomen, mèt de hoofden der gesneuvelden, ter vertoning aan Sénapati.

Toen de vluchtelingen voor de sultan kwamen, zag deze in, ,dat Sénapati-ngAlaga inderdaad in opstand was, daar hij de strijd was begonnen."

Het verhaal in de Serat Kanḍa (557-59) is heel wat eenvoudiger en veel minder romantisch uitgewerkt.

Tg. Majang's zoon dringt 's avonds tien uur de kaputrèn binnen en boeleert met een van des sultans dochters. Betrapt zijnde, wordt hij vermoord. $Z$ ijn vader vlucht uit vrees voor ongenade met zijn ganse huisgezin naar Mataram. De ondeugende dochter wordt door de sultan naar Semarang gezonden, om daar te blijven onder toezicht van de regent, pg. Samarang, zoon van sunan Bajat, de kleinzoon van Maulana Abdullah.

De keus tussen Babad en Serat Kanda valt ditmaal niet zwaar. Het Babad-verhaal is te romantisch, de dalende en rijzende muur duidelijk een sprookjesmotief. Doch er zitten in de Serat Kanḍa ook vreemde elementen. Terwijl het vervoeren van tg. Majang naar Semarang volgens de Babad onverklaard blijft, heeft het brengen der prinses daarheen volgens de Serat Kanḍa wel degelijk zin, n.l. zij kwam daar, ver van mogelijke belagers, onder deugdelijk geestelijk toezicht te staan. Doch, dit laatste ziet er wel echt Semarangs uit. De Serat Kanḍa toont op meer plaatsen in Semarang zijn eindredactie te hebben ontvangen. Daarom lijkt juist deze episode een later invoegsel. Dit is te betreuren, omdat dit een der weinige plaatsen in de historische literatuur is, waar sprake is van de grote apostel van Midden-Java ten Zuiden, sunan Bajat of kj. ageng Pandan-Arang.

Het onverwachte optreden der mantri's pamadjegan hangt ongetwijfeld samen met de voorafgaande historie van het winnen dezer lieden (Babad 76-77). Dit verhaal zag er, naar wij meenden, als een jong 
invoegsel in de Babad uit. De lezing van de Serat Kanḍa, zonder deze mantri's, zal daarom ook de oorspronkelijke zijn.

Merkwaardig is de openhartigheid, waarmede de Babad Sénapati aanwijst als de aanstichter van de oorlog tegen Padjang.

Deze verantwoordelijkheid voor de strijd wordt nog vergroot in de Sadjarah Bantĕn (p. 29-30), waar duidelijk op deze gebeurtenissen gezinspeeld wordt. $T g$. Majang wordt wel niet bij name genoemd, doch onmiskenbaar is hij bedoeld, wanneer er sprake is van de zoon van de dipati van Padjang. Deze is, volgens de aantekening van $\mathrm{H}$. Djajadiningrat, het vorige hoofd van Padjang, door Djaka-Tingkir verdreven uit zijn positie. Daar deze zoon het leven in Padjang voortdurend onaangenaam gemaakt werd, vlood hij naar Mataram en werd daar door ki gedé Mataram goed ontvangen, zelfs tot schoonzoon verheven.

Het feit, dat de Matarammers een voortvluchtige telg uit het oude heersersgeslacht in bescherming nemen, grenst al aan hoogverraad. De aanvaarding als schoonzoon betekent een breuk. Deze feiten alleen zouden reeds de oorlog tussen Padjang en Mataram afdoende verklaren.

\section{De slag bij Prambanan.}

De eerste veldslag tussen Sénapati en zijn ongelukkige leenheer was meteen ook beslissend, Babad 90-91 :

Nadat Sénapati zich in de zaak van zijn zwager op onregelmatige wijze recht verschaft had, gaf de tot dusver lankmoedige sultan van Padjang bevel aan zijn troepen, om zich gereed te maken en Mataram aan te tasten. Zelfs de bupati's der grensgewesten verzamelden zich. Genoemd worden des sultans schoonzonen, de adipati's van Demak, Tuban en Bantěn. Het grote, bonte leger rukte op; Z.H. bereed een olifant. Zij kampeerden in Prambanan.

Daartegenover kon Sénapati slechts 800 Matarammers in Randu-Lawang stellen. Kj. Djuru-Martani ontried de strijd, daar hij een nederlaag voorzag. Dus gaf hij in overweging, zich tot Allah te richten, d.w.z. Sénapati tot rara Kidul en hij zelf tot de god van de Merapi.

Tevens vergat hij de practische kant van de zaak niet: krijgslieden zouden in het Zuidergebergte veel hout opstapelen, gelijkmatig over de heuvels verdeeld, de stapels op een geweerschot afstands van elkaar. 's Nachts zou men dat alles te gelijk in brand steken.

Het programma werd afgewerkt. Sénapati en Djuru-Martani wendden het gelaat met gekruiste armen ten hemel. Inderdaad kondigden de djim's, peri's en prajangan's hun komst al aan door regen, wind en een luid gedruis. Daarop begon de Merapi te 
branden en te donderen. Een dichte asregen viel; modder met grote stenen vervulde de kali Ompak.

Doch tegelijk werden de houtstapels op het gebergte ontstoken, zodat dit één vuurzee geleek. „En zonder ophouden werd op.... ki Bitjak.... geslagen." Deze samenwerking tussen natuur en kunst beoogde slechts de Padjangers schrik aan te jagen.

Inderdaad sloeg de sultan de angst om het hart, waarvan ad. Tuban hem vergeefs poogde te verlossen, ook al meende hij alle Matarammers in een oogwenk te kunnen verdelgen. Integendeel, het was weer het oude deuntje. De sultan voelde zijn einde naderen en achtte zich de laatste vorst van Padjang. Sénapati zou zijn opvolger worden. $\mathrm{Hij}$ was slechts naar Mataram gekomen, om hem te aanschouwen!

Ondertussen namen de natuurverschijnselen een steeds schrikwekkender vorm aan. Het Padjangse heir sloeg op de vlucht en de sultan moest mee. „Zij meenden, dat ze door de vijand werden aangevallen. Het grote leger was ineens vandaar weggevaagd."

Veel minder zoetsappig ziet het verhaal in de Serat Kanḍa (559-69) er uit.

De overkomst van zijn zwager, tg. Majang, gaf Sénapati de kans, om nog meer aanhangers te winnen, en dus aan Padjang te onttrekken.

Deze feiten worden op een hofdag door 's vorsten schoonzoons (tg. Tuban en tg. Demak), onder diens aandacht gebracht, daar zij een oorlog noodzakelijk achtten. De sultan, ofschoon bewust van de a.s. val van Padjang, bezweek voor hun aandrang en droeg hun de oorlogvoering op. Hiertoe verklaarden zij zich bereid, mits de sultan mede aanwezig wilde zijn, hoewel enigszins in de achterhoede.

Een 10.000 man worden nu op de been gebracht. Pg. Benawa rijdt te paard achter zijn vader aan, die op een olifant gezeten is. Te Prambanan houdt men halt en versterkt zich met batterijen.

$\mathrm{Kj}$. ad. Mandaraka (Djuru-Martani), een zware strijd voorziende, spoort Sénapati aan, zich naar guwa Langsé (de grot van rara Kidul) te begeven, terwijl hij zelve naar de Merapi zal gaan, om hulp af te smeken. Na de terugkomst brengt Sénapati 1000 man bijeen, waarvan hij 300 bezuiden Prambanan opstelt. Dezen krijgen last om, bij enig geluid van de Merapi, dadelijk op kj. Bitjak te slaan en een geschreeuw aan te heffen. Tot aanvoerder wordt tg. Majang benoemd.

De strijd ontbrandt tussen twee afdelingen, waarbij de Matarammers moeten vluchten. Doch de achtervolgende Padjangers worden onverwachts door de 2 andere Mataramse afdelingen aangetast en uiteen geslagen. De duisternis beëindigt de strijd. Beide partijen keren naar hun stellingen terug. 
Die avond, te 7 uur, barst de Merapi uit onder duisternis, zware buien, asregen, aardbeving, bandjirs e.a. schrikwekkende verschijnselen. De Matarammers slaan dan op ki Bitjak. De overstroming bereikt het kamp der Padjangers, welke, met ontzetting geslagen, de vlucht nemen. De sultan wordt in het tumult meegesleept.

Dit verhaal ziet er heel wat natuurlijker en begrijpelijker uit, dan de voorstelling in de Babad. Vooreerst wordt er inderdaad bij gestreden, niet enkel bang gemaakt. Een uitbarsting van de vulkaan Mérapi, ofschoon hier toevallig met een veldslag samenvallende, is overigens nog geen zeldzaamheid. $\left.{ }^{1}\right)$ De kali Ompak, waaraan Prambanan ligt, kan lelijk bandjirren. Dat de bijgelovige Padjangers, door een rampspoedig voorhoedegevecht ontzenuwd, bij de aanschouwing der woedende elementen hun laatste restje moed verliezen en het hazepad kiezen, mag gans niet onmogelijk worden geacht. Alleen de tocht van Sénapati helemaal naar guwa Langsé lijkt wat te ver en is daarom onwaarschijnlijk. Mogelijk heeft hij zich tot een bezoek in de geest bepaald.

Daartegenover is de Babad, die hevige conflicten schuwt, er sterk op uit, om deze slag bij Prambanan als iets doodonschuldigs voor te stellen. De houtstapels in het ongetwijfeld toen veel houtrijker Zuidergebergte, zien er te wonderlijk uit, om veel vertrouwen te verdienen. Blijkbaar wilde men Sénapati's leger toch nog iets laten doen, want in beginsel mocht er niet gestreden, geen bloed vergoten worden. De sultan is ook bijzonder mismoedig.

Dat op het slagbekken ki Bitjak, afkomstig van kj. geḍe Sèla, geslagen is, wordt door beide geschriften bevestigd en is ook zeer aannemelijk. Zonder deze bovennatuurlijke wapens tijgt een vorst dier dagen nooit ten strijde.

Merkwaardig is, dat de Babad de aanwezigheid van de adipati van Bantěn in de Padjangse gelederen opmerkt. Ofschoon wij verder niets van een heerschappij van Padjang over Bantěn af weten, moet er toch

1) J. Crawfurd, in zijn: History of the Indian Archipelago (II, 325-26) vermeldt, op grond van "native writers", een hevige uitbarsting van een vulkaan, juist in het eerste jaar van Senapati's règering, n.1. A. J. 1508 (A.D. 1586). Hij vervolgt dan: „This was the same eruption, to which the Portuguese were witnesses; by their account hid the sun for three whole days, and destroyed ten thousand souls". Helaas vermeldt hij niet, bij welke Portugese of andere schrijver hij dit kostbare gegeven gevonden heeft. Twee jaar te voren moet er een hevige aardbeving hebben plaats gevonden (N. J. Krom, Inleiding tot de H. J. kunst. 2e herz. dr. 's-Grav. 1923. I, 445 noot). 
op gewezen worden, dat ook de Portugees de Couto Bantěn nog onder Padjang's onderhorigheden rekent.

De aanwezigheid der tumenggungs van Tuban en Demak, ja zelfs van adipati Bantěn onderstreept nog sterker het kustkarakter, dat het Padjangse rijk in de laatste jaren van sultan Adi-Widjaja's regering begon te verkrijgen. Tegen deze macht der Noorderstranden roepen nu Sénapati en Mandaraka de goden van het Zuidelijke binnenland op: die van de berg en de Zuidzee.

Ten slotte lijkt het volstrekt niet uitgesloten, dat de slag bij Prambanan een nog heviger karakter heeft gedragen, dan zelfs de Serat Kanḍa durft te suggereren, wellicht zelfs geëindigd is met een vernietigende achtervolging van het Padjangse leger.

\section{Sultan Padjang's wijken naar Bajat.}

$\mathrm{Na}$ zijn nederlaag bij Prambanan begaf de rampzalige vorst van Padjang zich naar het heilige Tembajat, waarover de Babad (91-92) verhaalt :

De arme voortvluchtige sultan wilde bij het graf van Tembajat bidden, doch het hek weigerde zijn dienst. De vorst kon het niet open krijgen, zodat hij maar daar buiten knielde.

De grafbewaker gaf een zeer ongunstige uitlegging van het geval: Blijkbaar verleende Allah hem geen toestemming meer, om vorst te zijn.

Dit trof de rampzalige vorst diep. 's Nachts sliep hij er in de balé kentjur (door water omgeven), wat hem zeldzaam verkwikte. De volgende morgen werd de aftocht voortgezet, doch de vorst viel van zijn olifant, waardoor hij ziek werd. Daarna besteeg hij een draagstoel. Zo sukkelde hij langzaam verder naar huis.

De Serat Kanḍa (569-71) is over deze gebeurtenissen veel beknopter :

Het begin is ongeveer gelijk. Te vergeefs poogt de vorst met de sleutel van de djuru-kuntji de deur te openen, en brengt daarom zijn hulde van buiten af. Dit schenkt hem het voorgevoelen, dat het einde van zijn regering en leven nabij is. Het nachtverblijf in de balé kentjur blijft onvermeld.

Het vallen van olifant komt van de wildheid van het beest. De vorst zet de tocht dus in een tandu voort. De verschillen zijn dus niet groot.

De overigens zeldzame vermelding van Tembajat in dit verband doet aan een soort van rijksheiligdom denken. Hierop wijst ook het jaartal 
A.J. 1488 (A.D. 1566) op een der nog aanwezige poorten. Des vorsten falen in het rijksheiligdom zou dan wel een duidelijk teken zijn, dat het einde van zijn rijk nabij is.

Trouwens, reeds eerder in de geschiedenis van tg. Majang blijkt er een zekere verhouding te bestaan tussen de Padjangers en het geslacht van Bajat (S.K. 559).

\section{De vervolging door de Matarammers.}

Dat de vervolging van het Padjangse leger in de overlevering een waardige vorm gekregen heeft, spreekt van zelf. Hierover meldt de Babad (92-93):

Sénapati volgde ondertussen de sultan eerbiedig met 40 ruiters. Pg. Benawa wilde de kans, dat Sénapati slechts weinig gevolg bij zich had, waarnemen, om hem te vernietigen, doch de sultan zeide rustig, dat dit volgen een eerbetoning beduidde van Sénapati, met wie de zoon steeds op goede voet diende te blijven, aan wie hij zelfs onderdanig moest wezen. Bij onenigheid zou hij zelfs geen vorst van Padjang kunnen worden. Onderwijl weenden de toehoorders.

Padjang werd bereikt, doch de kwaal van de sultan verergerde. Sénapati legerde zich nu in het dorp van zijn zwager, in Majang, weigerde dit te verlaten, om voor de sultan te verschijnen, doch wilde evenmin terug naar Mataram. Hij wenste er te blijven, om Allah's wil af te wachten. Daarop liet hij veel slasih-bloemen kopen en voor de westelijke poort van de alun ${ }^{2}$ opstapelen.

In de Serat Kanḍa (571-79) erkent de kranke vorst dadelijk de vriendelijke bedoeling van Sénapati om hem eerbiedig te volgen, en berispt niet zijn zoon, doch Sénapati's oude vijand, ad. Tuban, die Sénapati thans wil overvallen. Zelfs Sénapati's weigering om bij zijn sponde te komen, oogst lof bij de kranke en hij oordeelt: „Deeze mijn zoon is bijzonder geschikt tot een krijgsoverste."

Niet te Majang, doch bij het graf van zijn grootvader kj. gedé Ngenis in Lawijan legert zich Sénapati en de derde nacht droomt hij, dat de vorst weldra zal sterven. Dus laat hij zijn volk voor 10 Spaanse matten slasih-bloemen kopen en die voor de zijpoort ophopen.

Het valt moeilijk de beide schrijvers in hun al te zoetsappig betoog te volgen. 40 helden zijn vaak de uitgelezen schare, die een groot held begeleidt. Ad. Tuban past beter als kwade geest van de sultan, dan de goedhartige pg. Benawa, zodat de Serat Kanḍa wel weer gelijk zal 
hebben. De tegenstrijdige opgaven omtrent Sénapati's legerplaats: Majang of Lawijan, waren zo te combineren, dat men een omsingeling of blokkade van de kraton aanneemt. Sénapati's leger was in beide plăatsen om Padjang te belagen. Hierop wijst ook zijn weigering, om bij het sterfbed te verschijnen en het opstapelen der slasih-bloemen, kennelijk als grafbloemen bedoeld. Men kan dit als een hoon van Sénapati opvatten. De Babad Sengkala spreekt ook van „rusak Padjang”, wat er gans niet vredelievend uitziet.

\section{De dood van de vorst van Padjang.}

Over de dood van de vorst van Padjang geeft de Babad (93) nu eens een voor Sénapati heel onvriendelijk bericht:

„Toen kwam er een djim, Djuru-Taman.... Hij was de gunsteling van Sénapati onder diens dienaren. Maar alleen Sénapati zag Djuru-Taman.... Hij was groter dan een mens." Deze bood zijn heer aan, Padjang in te nemen en de sultan te doden: „Geef u mij dan maar bevel daartoe; stellig zal.... de sultan door mij de dood vinden." Sénapati gaf daarop een twijfelachtig antwoord: „.... ik dank je.... maar ik heb geen dgl. verlangen. Maar.... ga.... je gang, ik gebied het je niet, maar ik verbied het je ook niet." Djuru-Taman trok daarop naar de kraton van Padjang en Sénapati keerde naar Mataram terug.

Op dat ogenblik lag de sultan te bed, bewaakt door zijn vrouwen, terwijl zijn kinderen eerbiedig voor hem zaten. Pg. Benawa meldde de opstapeling van slasih-bloemen, waarvoor de sultan zich nog dankbaar toonde. „Daarop kwam... Djuru-Taman, maar niemand zag hem. Hij ging op de borst van de sultan zitten. De sultan viel.... flauw, en toe hij weer bijkwam, was zijn ziekte veel erger.... Het duurde niet lang, of hij overleed." Het lijk werd in Butuh begraven.

De Serat Kanḍa (576-77) levert merkwaardige verschillen op. Het lijkt bijna, alsof deze Sénapati van alle smetten wil zuiveren, want vóór de dood van de vorst keert hij naar Mataram terug. Djuru-Taman, die men op grond van het verhaal van zijn geboorte en in dienst treden bij Sénapati $(544-47)$ hier stellig zou verwachten, ontbreekt. De vorst sterft zijn natuurlijke dood. Zijn laatste woorden bevelen Sénapati aan, die men ter begrafenis moet noden en wiens raad men dient op te volgen. Bij zijn terugkomst in Padjang kust Sénapati de voeten van de dode onder een vloed van tranen. Ook hier begraaft men de vorst in „Boeto”.

Schakelt men het bovennatuurlijke uit, dan heeft het er alle schijn van, of ditmaal de Babad het bij het rechte eind heeft. Dan zou dus 
Sénapati de vorst van Padjang door een handlanger hebben laten vermoorden, hetgeen hem natuurlijk niet fraai staat. Waarschijnlijk zal de schrijver van de Serat Kanḍa deze geschiedenis ook gekend hebben, mogelijk zelfs nog in veel krassere vorm, omdat wèl de herkomst van de Djuru-Taman verhaald wordt. Doch wellicht is deze episode (later?) opzettelijk gewijzigd, omdat men dit toch wat al te bar vond.

Aan deze gestalte van de geheimzinnige Djuru-Taman wijdde dr. Pigeaud een beschouwing in zijn artikel: Alexander, Baron Sakèndèr en Sénapati (Djawa VII, 1927, 360). Hij noemt hem daarin een berggod, behorende tot de z.g. oudere linie, die de uitverkoren vertegenwoordiger der jongere linie, Sénapati moet leiden. Hij zou dan met kj. Djuru-Martani gelijk te stellen zijn.

Dit behoeft evenwel niet uit te sluiten, dat de handlanger van Sénapati, tevens moordenaar van de sultan, een persoon van vlees en bloed geweest is. Historische personen krijgen wel meer mythologische trekken.

Indertijd waagde ik de onderstelling (Proefschrift stelling 7), dat deze Djuru Taman wellicht een Italiaan geweest zou zijn, vermeld door sultan Agung in een gesprek met dr. De Haan in 1622 (d. J. IV, 308), over wie deze vorst mededeelde, dat hij voor ,lange jaeren.... by syn vaders tyden niet in syn hoff, maer buyten op syn crapiack" geweest was.

Inderdaad is er onder de regering van sultan Agung's vader sprake van een panakawan, een albino (dus: blank), Djuru-Taman geheten, die toen onrust in de kraton verwekte, doordat hij zich voor vorst uitgaf en vele vrouwen en bijvrouwen van Z.H. zich vergisten (Babad 117). Daarom werd hij binnen een lusthof (taman) ondergebracht, vandaar zijn naam: Djuru-Taman.

$\mathrm{Nu}$ is een krapjak (wildbaan) niet hetzelfde als een taman (bloemenhof), doch in beide gevallen kunnen wij ons een omheind stuk natuur voorstellen. Daarom is het wel aannemelijk, dat de panakawan-albino tijdens pan. Krapjak, dezelfde is, als de Italiaan vermeld door sultan Agung. Weliswaar is een Italiaan olijfkleurig van tint, doch stellig blanker dan de meeste Javanen. Ook zijn lichaamsgrootte is opvallend. Op p. 273 van de Babad wordt hij de klangenan, het vermaak van Sénapati genoemd.

Volgens mededeling van dr. Poerbatjaraka was de djuru-taman later een kratonambt, waartoe bij voorkeur vreemdelingen werden gekozen. Een hunner heette zelfs: Mas Djénggot (= baard), wat wel heel duidelijk op zijn vreemdelingschap wijst. Dit versterkt m.i. de hypothese omtrent de Italiaan. 
Daar het een ambt was, waarvoor men bij voorkeur vreemdelingen nam, ware het mogelijk, dat een handlanger van Sénapati, die deze functie bekleedde, ofschoon hij Europeaan was, toch onopvallend de vorst kon naderen, om op een onbewaakt ogenblik een plotseling einde aan diens leven te maken. Mogelijk bevond hij zich reeds aan het Padjangse hof, waar Sénapati verschillende handlangers telde. Zijn inlichtingendienst blijkt in orde te zijn!

Het gesprek tussen Sénapati en Djuru-Taman doet anders levendig denken aan zeker onderhoud tussen de eerwaarde Lohgawe en zijn veelbelovende leerling ken Angrok. Laatstgenoemde vraagt aan zijn geestelijke vader, of hij de regent van Tumapel ,door sluipmoord met een kris het leven benemen zal". Doch de brave Brahmaan antwoordt, dat weliswaar deze regent eens door ken Angrok's hand zal vallen, doch dat het voor hem als geestelijke ongepast is, hieraan zijn goedkeuring te hechten. „Doe evenwel, wat gij wilt” (Pararaton I, 10). Dit lijkt mij een hoogst bedenkelijke onzijdigheid.

Butuh, de begraafplaats van de Padjangse vorst, zoekt men soms ten Zuiden van de huidige kraton aan de Solo-rivier. Volgens dr. Poerbatjaraka zou echter diens graf ten Westen van zijn kraton aan de oude weg van Sura-Karta naar Karta-Sura liggen, niet ver van de spoorwegkruising, waar men inderderdaad een begraafplaats vindt, geheten: Makam-Adji (= het heilige graf van de vorst). Het zal onder sultan Agung nog een rol spelen (Babad 137, 205). ${ }^{\mathbf{}}$ )

Thans rest ons te pogen, het tijdstip van Padjang's val te bepalen. Wij zagen reeds, dat volgens de traditie de Mataramse kraton in 1578 zou gesticht zijn en dat volgens Jac. Couper (D. 1 Oct. 1684) de eerste vorst van Mataram zes jaar in die streek geleefd heeft. Zo kwamen wij tot 1584. De Serat Kanḍa (549) meent, dat Sénapati, nadat hij drie jaren niet aan het Padjangse hof verschenen was, daarmede in onmin raakte. Dat zou dus in 1587 geweest zijn. En nu stelt de vrij betrouwbare Babad Sengkala de ,verwoesting” van Padjang (Rusak Padjang) in A.J. 1509 (A.D. 1587). In dat geval zouden we dus een aardige overeenstemming verkrijgen. Weliswaar verschilt deze één jaar met het jaartal 1586, dat tot dusverre als het laatste jaar van Padjang's bestaan beschouwd werd en ontleend is aan Hageman's Tijdrekenkundig overzigt enz. (Handleiding I, 116-19), doch wij kunnen dit kloppend

1) Schrieke vermoedt op grond van andere versies, dat de vorst van Padjang vergiftigd is. 
maken door op Hageman de correctie toe te passen, besproken in B.K.I. CVIII 1952 p. 165 . Ook Raffles' Chronological Table heeft 1587.

Heeft Sénapati nog meer gedaan dan oorlog voeren in dat jaar 1587 ? Mogelijk wel. Op de kelir van de buitenpoort der moskee in Kuṭa Geḍé komt een jaartal voor: Djimawal 1509 (A.D. 1587). Heeft hij zijn zege over Padjang met de voltooiing van een bouwwerk, gewijd aan de godsdienst, willen vieren? 


\section{HET DEMAKSE TUSSENSPEL.}

De twist over de opvolging.

Over de opvolging van de vorst van Padjang deelt de Babad (93-94) het volgende mede:

$\mathrm{Na}$ het overlijden van de sultan en diens begrafenis te Butuh, verzamelden zich de kinderen, familieleden en bupati's in de binnenvertrekken van de kraton. Ook sunan Kudus en Sénapati waren aanwezig.

Men besprak er de vraag, wie der kinderen van de overledene zou opvolgen. De bupati's verkozen pg. Benawa, doch sunan Kudus gaf de voorkeur aan een schoonzoon, de adipati van Demak, gehuwd met een oudere zuster van Pg. Benawa. Laatstgenoemde moest maar dipati van Djipang worden.

Sénapati wilde juist wat te berde brengen, doch zijn oom legde hem het stilzwijgen op. Aldus kreeg sunan Kudus zijn zin en pg. Benawa moest tot zijn ergernis naar Djipang. Sénapati toog huiswaarts en volgde de raad van zijn oom op, om zich nergens mee te bemoeien. Hij bad en gaf sedekah's voor de overleden vorst.

In de Serat Kanḍa (579-82) staat het verhaal iets eenvoudiger. Sunan Kudus is reeds door de stervende vorst ontboden en aangekomen. $\mathrm{Hij}$ treedt zeer eigenmachtig op, houdt een rede tot het volk, waarin hij eenvoudig zijn beslissingen mededeelt, n.1.: het sultanaat voor Z.H.'s oudste schoonzoon, de adipati van Demak; Djipang voor pg. Benawa. Daarop vertrekt hij en men hoort daarna weinig meer over hem. Sénapati en zijn oom gaan ook heen na een wrange opmerking van laatstgenoemde: men maakte zich drukker over het verdelen van de erfenis, dan over de begrafenismalen.

Sénapati heeft weliswaar een einde gemaakt aan de regering van Padjang's vorst Adi-Widjaja, doch daarmede is hij nog lang niet alleenheerser. Dit staat trouwens duidelijk in de officiële kronieken (Babad 92 en Serat Kanḍa 577). De invloed van de kust, die in de personen der tumenggungs Tuban en Demak reeds zeer machtig aan het Padjangse hof was, wordt nu nog versterkt door de komst van de welbekende sunan Kudus, een machtig geestelijk heerser. Volgens de Serat Kanḍa was deze zelfs nog te elfder ure door de stervende sultan 
naar Padjang geroepen en zou nog juist vóór diens overlijden daar aangekomen zijn. (De Serat Kanḍa is enigszins Kudus-gezind.) Welk een gezag dit heerschap bezat, blijkt wel heel duidelijk uit de Serat Kanda. Hij treedt er op als een dictator, of liever als een paus. Was zijn tegenstander, sunan Kali-Djaga, soms overleden? In hem mag men wel de stem der kust vernemen. Sénapati ziet zich dus in deze persoon geplaatst tegenover het verzet der stranden, dat hem in het defensief dringt. De onstuimige Matarammer wil zich ook tegen deze nieuwe, gevaarlijke macht verzetten, doch zijn wijze oom legt hem het zwijgen op en beweegt hem, zich voorlopig op de achtergrond te houden. De adipati van Padjang heeft dus vrij spel. Listig worden te zijnen behoeve de twee andere candidaten naar de Padjangse troon, Sénapati en Benawa, van elkander verwijderd, de een in het binnenland: Mataram; de ander in het kustgebied: Djipang, dat toen, wellicht door Sura-Baja's afval, grensgebied was.

Ten overvloede blijkt uit dit verhaal, dat de rol van het geslacht van Demak nog allesbehalve was uitgespeeld. Het poogt zelfs onder Kudus' leiding opnieuw de teugels in handen te krijgen, doch, en dit is kenschetsend, niet meer vanuit het heilige Demak, maar vanuit de binnenlandse hoofdstad Padjang en op grond van zijn huwelijk met de dochter van Padjang's sultan. Java's politiek zwaartepunt is dus bezig zich voor goed te verplaatsen van de kust naar het binnenland.

Het politieke spel in Padjang heeft intussen blijkbaar de officiële begrafenisplechtigheden doen verwaarlozen. Sénapati maakt dit verzuim in Mataram weer goed, hoewel niet zonder politieke bijbedoeling.

Wij weten intussen niet nauwkeurig, hoe de verwantschap was tussen sunan Prawata, die in 1549 op last van pg. aria Panangsang werd vermoord, en deze adipati van Demak. Hageman noemt hem eenvoudig een zoon van sunan Prawata, aria Pangiri geheten, over wie zich de vorst en vorstin van Kali-Njamat, na de vermoording van zijn vader, ontfermden (Handleiding I, 69-73). Het is daarom zeer wel mogelijk, dat deze aria Pangiri en de adipati van Demak een en dezelfde persoon zijn.

\section{Adipati Demak is vorst van Padjang.}

Het falen van de adipati van Demak wordt beschreven in Babad 94-95 :

De adipati van Demak vestigde zich te Padjang, waarheen hij vele lieden uit Demak overbracht. Voor dezen werd $1 / 3$ deel der 
akkergronden in beslag genomen, terwijl zij ook allen één trap bevorderd werden.

De onterfde Padjangers werden ontevreden en vervielen tot misdaden. Sommigen verhuisden zelfs naar Mataram. De mantri Pangalasan rapporteerde deze wanorde aan Sénapati en vuurde hem aan, vorst te worden. Stellig zouden alle Padjangers naar hem overlopen. Sénapati antwoordde afwijzend, doch met de toevoeging: „Wanneer er een opdracht zal zijn van Allah en ik bevel zal krijgen, vorst te worden,.... zal het gemakkelijk zijn, Padjang te verwoesten."

Deze ganse episode ontbreekt in de Serat Kandia, te gelijk met de mantri Pangalasan, stellig een bepaald hoofdambtenaar, die Sénapati reeds eerder had gewaarschuwd (Babad 83). Zijn dit familieherinneringen, bij afstammelingen van deze ambtenaar bewaard? De medegedeelde bijzonderheden zijn anders waardevol. Terwijl de Serat Kandia op p. 586 eenvoudig vermeldt, dat de nieuwe vorst „het regt en de geregtigheid van de oude wetten ten eenemaal op zeijde geworpen had", krijgen we hier meerdere bijzonderheden. De Demakse prins gevoelde zich zo weinig op zijn gemak tussen de Padjangers, dat hij zijn eigen aanhang uit Demak meebracht. Dit gevolg behoefde voedsel en schittering. Voor het eerste zorgde het afgenomen derde deel der akkers, voor het andere de algemene bevordering. De kustadel verhief zich boven de ruwe binnenlanders. Daarom ontstond er in Padjang een gewelddadig verzet. Een en ander klinkt zeer waarschijnlijk.

De ontevredenheid van pg. Benawa is het onderwerp van Babad 95-96:

Pg. Benawa was in Djipang heel verdrietig, at en sliep weinig. 's Nachts sliep hij onder de drup van het dak. Eens droomde hij, dat wijlen zijn vader hem opdroeg, bij Sénapati om hulp aan te kloppen. Dus zond hij de volgende morgen een bode naar deze, ter ontbieding naar Djipang. Sénapati weigerde, wilde zich niet in familietwisten mengen. Mataram was hem voldoende.

Daarom zond pg. Benawa de bode nogmaals, dit keer met het aanbod van het rijk Padjang, want als de dipati van Demak opvolgde, stierf hij liever.

Toen Sénapati dit aanbod vernam, ,was hij zeer blij en had medelijden met zijn jongere broer. Hij noodde deze uit, via het Zuidergebergte tot hem te komen, en hij zou hem daar tegemoet gaan.

Te Weru in het Zuidergebergte had inderdaad de ontmoeting plaats. Ze omhelsden elkaar en overlegden in een pondok. 
De Serat Kanḍa (582-85) zegt als gewoonlijk de zaken iets korter en scherper. $\mathrm{Na}$ de droom met de stem (van zijn vader?) vraagt pg. Benawa Sénapati om hulp en biedt Padjang aan. Deze nodigt hem echter uit naar Mataram over te komen. Dientengevolge begeeft pg. Benawa zich met 1000 Djipangers derwaarts. Sénapati haalt hem te Randu Gunting af. In Mataram besluiten zij Padjang aan te vallen.

In het regentschap Sura-Karta ligt een Weru. De weg door het Zuidergebergte is redelijker dan die over Randu-Gunting, dat bij Prambanan ligt, de officiële, grensplaats tussen Padjang en Mataram. Ook overigens geeft de Babad een aannemelijker voorstelling, b.v. in Sénapati's geraffineerd weigeren na Benawa's eerste verzoek, om, nadat aan al zijn wensen door het tweede voldaan is, ogenblikkelijk toe te happen. Benawa's onaangename positie heeft hij zeer behoorlijk uitgebuit.

\section{Sénapati en Benawa veroveren Padjang.}

De tweede verovering van Padjang verhaalt de Babad op p. 96-98:

Toen de Padjangse soldaten van ad. Demak vernamen, dat pg. Benawa terug was, liepen zij allen over, zodat de Demakker slechts zijn meegebrachte manschappen overhield. Deze afval bracht Sénapati en Benawa in de waan, dat de verovering wel mee zou vallen en Sénapati stelde voor, de volgende morgen maar tot de aanval over te gaan. Benawa met de overgelopen Padjangers van de Oostzijde, Sénapati met de Matarammers van de Westkant.

Het leger van ad. Demak bestond uit vrije Demakkers en „slaven”. De laatsten, bestaande uit gekochte Balinezen, Boeginezen en Makassaren, werden toegesproken. Zij zouden Sénapati met gouden en zilveren kogels bestrijden. De slaven namen plaats op de vestingwal, de vrije lieden op het erf.

De strijd ving aan met een hevig geweervuur o.a. op Sénapati en zijn goudvos Brata-Juda gericht, zonder enige uitwerking. Ook de geesten deden mee. Listig beloofde Sénapati de slaven de vrijheid, zodat zij allen deserteerden. Een mantri van Padjang, kj. Geḍong, opende de Westpoort, niettegenstaande het verzet der Demakkers. Zo kwam Sénapati binnen en deed aan kj. Geḍong een gelofte. Deze sneuvelde daarna op de alun ${ }^{2}$, wat Sénapati ontstelde.

Terwijl de Demakkers hevig werden aangevallen, knielde Sénapati in gebed tot Allah. Eerst toen de overwinning behaald was, riep zijn oom hem tot de werkelijkheid terug. Te voet betrad Sénapati eerbiedig de pagelaran en sitinggil van wijlen Z.H. de sultan. 
Aan de 1e poort ontmoette hij diens dochter, echtgenote van ad. Demak, die hem wenende de voeten kuste en om genade smeekte voor haar man. Sénapati verleende hem die genadiglijk, mits hij zich overgaf en gewillig liet binden.

Op de sitinggil ontmoetten elkander de overwinnaars; vóór hen zat met gebogen hoofd de ad. Demak, geboeid met een zijden doek. Sénapati verweet hem, zich van Padjang te hebben meester gemaakt, dat hem niet toekwam. In een draagstoel werd hij vervolgens weggevoerd naar Demak, waar men hem pas mocht losmaken.

De Serat Kanḍa (585-88) is veel beknopter:

Als het leger der verbondenen in Prambanan komt, lopen 3000 Padjangers over. Vervolgens rukt men naar Majang op, van waaruit Padjang belegerd wordt. De 2000 man, die ad. Demak van de kust heeft meegebracht, verdeelt hij over de 4 zijden der stad. 400 Makassaren, Buginezen en Peranakans plaatst hij op de alun ${ }^{2}$. Sénapati valt van de Noord-, Benawa van de Zuidzijde aan. In weinige uren is de strijd beslist.

In de Babad is Sénapati, zelfs op het ogenblik der zege, tevens de vrome Javaanse Moslim, die zijn gedachten midden in het gevecht toch op Allah weet te concentreren. De overwinning valt hem daardoor als het ware in de schoot.

Opvallend is het bonte leger van de adipati van Demak: $1^{\circ}$ Padjangers (3000); $2^{\circ}$ Demakkers (2000); $3^{\circ}$ overwalsen (400). De Babad noemt hen gekochte slaven. Is dit in ernst, of slechts als scheldwoord voor huurtroepen bedoeld, zoals de Compagnie ze later in dienst zou nemen? Dit past het beste bij een staat met een geldhuishouding, zoals wij van de kustrijkjes enigszins mogen verwachten. Op deze ruilmiddelen van edel metaal zinspelen waarschijnlijk ook de zilveren en gouden kogels. Ook bezaten die van de kust allicht meer vuurwapens dan de lieden uit de bergen. Gelukkig, dat Sénapati en zijn rijdier daar onkwetsbaar voor waren. Ook het verhaal van kj. Gedong kan wel een traditie zijn, afkomstig van, of betrekking hebbende op een bepaald geslacht van mantri gediongs, en aldus bewaard gebleven.

Het voorkomen van peranakan-Chinezen als soldaten is in die dagen niets vreemds. Te Giri worden ze meermalen aangetroffen (vgl. Babad 139). De overwonnen adipati van Demak wordt als een edelman behandeld.

De sterke gedachtenconcentratie van Sénapati zou ook op een met moeite behaalde overwinning kunnen wijzen. 
Hoe hebben de overwinnaars hun zege benut? De Babad (98-100) meldt hierover :

$\mathrm{Na}$ het zegefeest bood pg. Benawa aan Sénapati het rijk aan. Hij zelf begeerde slechts als edelman te leven. „Ook de kostbaarheden, door.... Z.H. nagelatën, laat ik te Uwer beschikking."

Sénapati weigerde, wilde slechts vorst zijn van Mataram, hem door de sultan geschonken. „Wat Padjang betreft, hier zal ik U tot vorst aanstellen.... alleen vraag ik.... de gong kj. SekarDelima, het paardebit kj. Matjan-Guguh, het zadel kj. Gataju en dgl. pusaka's. Hij kreeg ze alle.

Daarop werd Benawa plechtig tot vorst over Padjang geinstalleerd. Sénapati zat daarbij op een gouden stoel en Benawa op een ander zitmeubel. Eerstgenoemde bezigde de wijdingsformule, die later in Mataram gebruikelijk zou wezen: „Bupati's en mantri's, weest gij allen getuige, dat ik mijn jongere broeder, pg. Benawa tot sultan verhef.... om over het rijk Padjang te heersen als opvolger van.... mijn vader." Allen gaven door een goedkeurend gemompel hun instemming te kennen, en hun ontzag voor Sénapati steeg nog, daar niemand verwacht had, dat Benawa sultan zou worden. Daarna gaf Sénapati nog enige wijze lessen over de 3 groepen, die Benawa bij moeilijkheden diende te raadplegen: de geestelijken, de sterrewichelaars, de asceten.

Op blz. 102 wordt kort medegedeeld, dat pg. Benawa pas een jaar sultan was toen hij stierf.

Geheel anders is de kijk, die de Serat Kanḍa (589-90) op deze gebeurtenissen heeft:

Als de weg tot de troon voor pg. Benawa geopend is, krijgt hij er op eens afkeer van, doch vertelt het niemand. In stilte begeeft hij zich naar de rivier, en laat zich meedrijven tot Sidaju toe. Vandaar zet hij de reis te land Westwaarts voort tot Parakan (Kendal). In een hol van de berg Kukulan slijt hij zijn dagen met vasten en bidden. Na voleindiging van zijn tapa verheft hij zich tot wali, bouwt in Parakan zijn dalem en heet sedert bij de bevolking: susuhunan Parakan. Sénapati, zijn broeder missende, stort een vloed van tranen.

Of de heilige van Parakan gelijk te stellen is met pg. Benawa, valt te betwijfelen. Wij kunnen dus het stuk ná zijn geheimzinnige verdwijning uit Padjang voorlopig ter zijde laten. Het zal wel een Samarangs invoegsel zijn! Dan hebben wij tussen beide lezingen van benawa's einde de overeenstemming, dat $\mathrm{pg}$. Benawa geruisloos van het 
staatstoneel is verdwenen, nadat hij er kort, of in het geheel niet op had geschitterd.

Over de aanstelling van pg. Benawa door Sénapati in eigen persoon, welke alleen in de Babad voorkomt, kunnen wij slechts zeggen, dat wij er even verbaasd over staan als de Padjangers. De raad, die Sénapati na de plechtigheid aan pg. Benawa schenkt, is belangrijk voor de $18 \mathrm{e}$ eeuw, minder voor de $16 \mathrm{e}$.

Van groot en blijvend belang is slechts, dat Sénapati de gevraagde pusaka's niet slechts verzoekt, doch ook verkrijgt. Reeds vaker merkten wij op, dat Sénapati en zijn vader zeer gesteld waren op pusaka's. Zij worden het eerst in een Nederlandse bron vermeld in het reisverslag van de kommandeur Govert Cnoll dd. 20 Jan. 1709.

\section{Ondergang van Demak.}

Wij dienen thans na te gaan, hoe het met de rijken Demak en Padjang verder gegaan is.

Zo min in de Babad als in de Serat Kanda wordt over Demak verder iets belangrijks verteld. Slechts de Babad Sengkala deelt voor het Javaanse jaar 1510 (A.D. 1588) mede: Rusaké nagri Demak, salungané Dipati tilar pradja, angambang ing sagara. Hier wordt dus gesproken over het heengaan van de Dipati (van Demak), die een reis over zee gaat maken. Voor hetzelfde jaar geeft de Babad Momana kort en krachtig : sirna kița Demak, sareng Dipati Demak dipun butjali: de stad Demak verdwijnt, en de dipati van Demak wordt verbannen. Raffles heeft : 1510 (A.D. 1588) Destruction of Démak, when the chiefs and people betook themselves to their vessels, and put to sea. Alleen Hageman, zelden feilloos, stelt deze gebeurtenis in 1590 .

Indien dit jaartal 1588 juist is, zou Demak's verwoesting snel gevolgd zijn op het Demakse avontuur in Padjang. Lang daarna kan zij in ieder geval niet hebben plaats gevonden, want het moet zeker enige jaren vóór de eerste Schipvaert der Hollanders voorgevallen zijn. Dezen immers melden, dat „Dauma een seer stercke, bemuerde Stadt” is, ,alwaer de voorsz. Keyser (n.l. die van Mataram) noch voor Koningh ghekent wordt'. Een zelfstandig Demaks vorst is er dus sinds lang niet meer; de Matarammer, die men toen een ogenblik meende te zien achteruitgaan, was er nòg steeds de baas, vermoedelijk al sedert enige jaren.

Een der vluchtelingen, die Demak had moeten verlaten, was een zekere pg. Mas geweest, welke op 1 Juli 1596 in Bantam was ver- 
schenen. De Portugezen noemden hem Raja d'auma (radja Demak), zodat hij in ieder geval lid van het Demakse vorstenhuis moet geweest zijn. De Sadjarah Bantěn acht hem een verwant van de sultan van Demak. Hij had bij zijn aankomst in Bantam reeds veel rondgetrokken. De Portugezen beschouwden hem zelfs als keizer, omdat zijn vader over de meeste koningen van Java ,absolutelijck gebiet” gevoerd had. Hij kan dus een zoon van Trenggana, doch ook van de hier voren genoemde adipati Demak geweest zijn. Het laatste komt mij het waarschijnlijkste voor. Daar hij lange tijd in het Portugese Malakka had vertoefd en de Portugezen zeer genegen was, wilden de Javaanse vorsten hem niet meer erkennen. Toch werd hij overal nog goed en eerbiedig ontvangen en door de vorsten met gevouwen handen aangesproken. In gezelschap zijner beide zonen (onder welke een 20 jaren telde), bezocht hij de Nederlandse schepen van Houtman en de Keyzer.

Ook de Engelsen kenden hem. De resident Scot te Bantam noemt hem keizer van Dema $k$ en verhaalt, hoe hij over zee van Bantam naar een andere kustplaats reizende, in Nov. 1604 door een zijner zonen in bed doorstoken werd. Hij zou ook, ,niet vele jaren geleden, wegens tyrannie door de omliggende koningen afgezet" zijn (Sadjarah Bantěn 149-150). Zou met die tyran ook zijn vader bedoeld kunnen wezen?

Deze vader van pg. Mas was dan misschien de adipati van Demak, die Hageman aria Pangiri noemt, welke immers als sultan van Padjang nog een blauwe Maandag heerser over gans Java was geweest.

De lange tijd, die deze man dus in Malakka heeft doorgebracht, moet dus tussen 1588 en 1596 vallen. Dientengevolge kan de verovering en verwoesting van Demak, die aan dit Malakse verblijf vooraf ging, niet ver van 1588 verwijderd zijn.

Men vraagt zich echter af, waarom Babad en Serat Kanda zo volstrekt over Demak's ondergang zwijgen. Twee mogelijkheden staan er open. Vooreerst kan men, beschaamd over de aanranding van het zo heilige Demak, deze pijnlijke geschiedenis liever zwijgend voorbij zijn gegaan. Ten tweede is het mogelijk, dat Demak niet door Sénapati van Mataram, doch door zijn familielid, ad. Pragola I van Pați is veroverd. Dan viel het automatisch buiten het terrein der officiële kronieken.

De enige chronologische aanwijzing, die de Babad misschien zou kunnen geven, is het feit, dat het hoofd van Demak, hetwelk deelneemt aan de tocht tegen Giri (1589?), nog adipati heet (p. 102), terwijl datgene, hetwelk aan de veldtocht naar Keḍiri meedoet (1591), slechts bupati genoemd wordt (p. 111). Bij benadering komen wij dan tot het jaartal 1590 voor de val van het rijk Demak. 
Nadat Sénapati zijn vriend pg. Benawa in Padjang had bevestigd, verhaalt de Babad (102) bijna onmiddellijk diens dood:

Pg. Benawa was slechts een jaar sultan en stierf toen. Zijn opvolger was Sénapati's jongere broeder, pg. Gagak-Baning, die slechts dipati van Padjang werd. Dank zij diens krachtig bestuur waren alle Padjangers onderdanig.

Doch hij wenste niet meer in de oude kraton te wonen en verhuisde Oostwaarts. „De stadswallen werden uitgelegd”, waardoor het graf van een gelovige uit Arabië daar binnen kwam te liggen, ,zodat de heilzame invloed ervan ondervonden werd. De stad Padjang had nu een vierkante vorm."

Kort daarop overleed pg. Gagak-Baning en werd door zijn zoon, pg. Padjang, opgevolgd.

De Serat Kanḍa (596) geeft een enigszins andere voorstelling: $\mathrm{Na}$ het reeds besproken vrijwillig zich terugtrekken als kluizenaar van pg. Benawa, dat onmiddellijk volgt op de val van Padjang, treedt Sénapati's jongere broeder, rd. Tompo als pg. Gagak-Bening, adipati van Padjang op.

Onder zijn bewind wordt het hof afgebroken en een nieuw, „dog in andere smaak... bewesten de oude", opgebouwd, ,zo dat de grafsteede van den overleedene Zulthan kwam te vallen binnen dese nieuwe Hoofd Stad".

Slechts drie jaren had pg. Gagak-Bening geregeerd, toen hij stierf. In zijn plaats werd benoemd ,als regent ... de eenigste nagelatene zoon van den te Parakan overleeden Pg. Benowo... oud 13 jaaren, onder den naam van zijn overledene vader: Pg. Benowo".

Een derde voorstelling vinden wij bij J. Hageman (Ind. Archief 22, $269,273)$ : Na Benawa's vrijwillige afstand, werd zijn broeder „GadjaBoemi” over Padjang aangesteld. Doch toen deze spoedig overleed, „verkreeg Radin Sida-Wini, zoon van Benowo, het vasalschap van Padjang”. Deze zou de laatste vorst van Padjang geweest zijn.

Trachten wij thans deze drie voorstellingen tot één terug te brengen. Waarschijnlijk is pg. Benawa, nadat hij al of niet korte tijd - hoogstens één jaar echt sultan was geweest over Padjang, al of niet vrijwillig heengegaan. Een verhuizing naar de rand des rijks als geestelijke is soms een soort van verbanning. Ook Hageman vermeldt pg. Benawa's verlaten der wereld.

Sénapati waagde het toen een lid zijner familie, n.1. zijn jongere 
broeder pg. Gagak-Baning over Padjang aan te stellen. In de Sadjarah Dalem (gen. 131) komt deze voor als het 12e kind van kj. geḍe Pamanahan, eerst geheten rd. Bagus Tompe, later pg. tg. Gagak-Baning ing Padjang of pg. Gagak-Pranala. Wellicht is deze dezelfde als de GadjaBoemi van Hageman.

Ook deze bestuurder van Padjang was slechts kort aan het bewind: drie jaar.

Omtrent zijn opvolger bezitten wij tweeërlei tijding. Volgens de Babad volgde Gagak-Baning's zoon op onder de naam van pg. Padjang; een zeer vaag bericht. De Serat Kanḍa en Hageman vermelden echter de enigste zoon van pg. Benawa, wie de eerste de naam zijns vaders, pg. Benowo toekent, terwijl de andere hem Radin Sida-Wini noemt. Wij kunnen dit verschil oplossen, door aan te nemen, dat de laatste naam een jeugd-titel is, doch dat hij de eerste als vorst droeg.

Wij krijgen dan ongeveer de volgende lijst van regeerders van Padjang:

Pg. Benawa 1587-88;

Pg. Gagak-Baning 1588-91;

Rd. Sida-Wini, pg. Benawa Jr. 1591-1617.

Onder de tweede regeerder, dus tussen 1588 en 1591, zou een ingrijpende verandering hebben plaats gevonden in de aanleg van de Padjangse kraton.

De Babad (102) spreekt van een verhuizing Oostwaarts, waarbij de stadswallen werden uitgelegd, om het graf van een Arabisch gelovige er binnen te sluiten.

De Serat Kanḍa (596) weet van een algehele vernieuwing, Westelijk van de oude kraton, zodat het graf van de oude sultan er binnen kwam te liggen.

Hoe het ook zij, men is radicaal aan het slopen en herbouwen geweest, waarbij wij de keus tussen een verplaatsing naar het Westen of Oosten hebben. Het laatste is bezwaarlijk, omdat men dan dadelijk tegen Lawijan en de grafmoskee van Ngenis op zit. Het eerste daarentegen is aannemelijker, omdat zo doende de graven van Makam-Adji binnen of vlak bij de nieuwe kraton zouden komen te liggen. Te Makam-Adji zou n.l. volgens dr. Poerbatjaraka het graf van de oude sultan van Padjang kunnen liggen, zodat daarmede de voorstelling in de Serat Kanḍa zou kloppen. Het graf van de Arabische gelovige en de verhuizing naar het Oosten dienen echter verworpen te worden. Wat de vierkante vorm betreft, deze is, zo lang geen behoorlijke opgra- 
vingen zijn gedaan, niet na te gaan. $\mathrm{Zij}_{\mathrm{ij}}$ is echter karakteristiek voor de latere kraton Plèrèd (1647-77).

\section{Sénapati's verheffing tot panembahan.}

Over Sénapati's nieuwe titel na de nederlaag van ad. Demak is de Babad (100) opvallend kort.

$\mathrm{Na}$ de plechtige aanstelling van pg. Benawa tot sultan keerde Sénapati huiswaarts en ,trad daarop op als sultan van Mataram. Maar zo werd hij niet genoemd; het publiek noemde hem slechts panembahan Sénapati."

Hierop volgt een reeks bevorderingen van familieleden.

De Serat Kanḍa (593) deelt mede, dat Sénapati op de 8e dag na zijn aankomst in Mataram plechtig op de paseban, omgeven door zijn ganse familie, terwijl ki Djuru-Martani voor hem zat, door zijn volk verheven werd tot panembahan, onder aanhouding van zijn oude naam Sénapati Ingalaga.

De moeilijkheid is hier, dat er zoveel onzekerheid bestaat omtrent de Javaanse titels der 16e eeuw. Het ,panembahan” komt, afwisselend met „pangéran”, pas zéker bij sultan Agung voor, doch kan ook wel eerder zijn voorgekomen. Een promotie op dit tijdstip van overwinning is trouwens aannemelijk.

Sénapati had ook bijna de titel van de vorst van Padjang, n.l. die van sultan. Doch wij weten, dat de Padjanger vermoedelijk nooit sultan heeft geheten, zodat ook Sénapati er moeilijk mee kon pronken. Wij bespraken deze kwestie reeds elders, waarbij wij tot de slotsom kwamen, dat de z.g. sultan van Padjang feitelijk niet meer dan pangéran adipati zal zijn geweest, terwijl Sénapati misschien pangéran Ingalaga genoemd werd.

$\mathrm{Bij}$ een vorstelijke verheffing behoren tevens bevorderingen van familieleden, broeders en zonen, zo mede die van de rijksbestuurder.

Enige der hier genoemde verheffingen verdienen een nadere beschouwing, n.l. die tot pg. Singa-Sari, pg. Puger en pg. Djuminah. Nu staat Djuminah voor Blitar (H. J. de Graaf, De reis van Mangku-Rat IV naar Mataram. T.B.G. LXXXIII 1949 p. 353). Wij krijgen dan de namen van drie aaneensluitende gebieden, die echter van zodanige geringe betekenis zijn, dat men zich afvraagt, waarom juist naar deze, in de $17 \mathrm{e}$ eeuw schaars bevolkte streken, zo voorname pangérans genoemd werden. 
$\mathrm{Nu}$ draagt een dezer gewesten de wijd beroemde naam van SingaSari, Madja-Pait's voorloper. Dat Sénapati zijn broeder naar dit vermaarde rijk noemde, betekent een ernstige pretentie. Kennelijk wilde hij de heersers in de Oosthoek overtroeven door zijn broeder met een titel te versieren, welke voor ouder en oorspronkelijker dan Madja-Pait kon doorgaan.

Meer moeilijkheden bieden Blitar en Puger, beide in de $17 \mathrm{e}$ eeuw onaanzienlijke gebieden, zonder sterk levende historische herinneringen, zodat zij ook in de Pararaton ontbreken. Mogelijk wilde Sénapati in Oost-Java een spiegelbeeld vormen van het Mataramse rijk, zoals het er in 1588 uitzag, n.l. het eigenlijke Mataram in het midden met aan weerszijden Bagelen en Padjang. Zo zou Singa-Sari in het Oosten door Blitar en Puger geflankeerd worden. Met de verheffing van de pangérans Singa-Sari, Blitar en Puger bedoelde Sénapati dus wellicht een aanspraak op een dergelijk gebied in Oost-Java, als hij reeds in MiddenJava bezat. Zulk een aanstelling zou men dus als een soort regeringsprogramma, ja, wellicht als een oorlogsverklaring kunnen beschouwen.

Sénapati's daarop volgende reis naar de Oosthoek, om de priestervorst van Giri te bezoeken, kan tevens ten doel hebben gehad, diens steun voor dit programma te verwerven, terwijl het gewapend tegemoet treden van de vorst van Sura-Baja als een duidelijk antwoord op een ultimatum zou zijn te beschouwen.

Ook de benoeming van pg. Purbaja draagt een minder vriendelijke bedoeling. Purbaja is een oudere naam voor Madiun. Met deze aanstelling pretendeerde Sénapati dus ook het gezag over het gebied van zijn Oostelijke buurman. Naar Madiun zelve kon hij zijn verwant niet noemen, want men aapt geen eenmaal bestaande titel na. Hij koos, om te concurreren, een oudere, oorspronkelijker naam, zoals Singa-Sari ouder was dan Madja-Pait.

Een zelfde onvriendelijke strekking had wellicht ook de aanstelling van Sénapati's zevende zoon Djaja-Raga (= Djaga-Raga?), zo genaamd naar het gebied Djaga-Raga, dat tussen Padjang en Madiun gelegen was.

Het genoemd worden van een gewest betekent geenszins, dat men er ook bewind voert. Later blijken deze titelvoerders gans andere plaatsen te besturen, dan naar welke zij heten.

Opvallend is, dat géén dezer hoge heren naar Kediri heet. Hiermede blijkt ook later iets bijzonders aan de hand te wezen. Wilde Sénapati deze mogelijke bondgenoten niet voor het hoofd stoten?

In den vervolge blijkt ook, dat deze met schijntitels versierde groten, 
toch een zeer belangrijke rol in de Mataramse geschiedenis spelen. Men lette er slechts op, hoe de pangérans Blitar (Djuminah), Singa-Sari, Puger en Purbaja tijdens het tweede beleg van Batavia in 1629 opzettelijk naar voren worden geschoven en er na de mislukking ongestraft afkomen, in tegenstelling tot de kleinere goden met minder klinkende namen.

Ten slotte wijzen wij er op, dat ofschoon voor dergelijke hoge persoonlijkheden de Babad e.a. officiële geschriften meestal de titel van pangéran gebruiken, het waarschijnlijk moet worden geacht, dat deze heren het over het algemeen vóór omstreeks 1640 niet verder brachten dan kjai adipati. Voor het gemak blijven wij echter de pangéranstitel bezigen. 


\title{
SÉNAPATI'S STRIJD OM DE LEIDING. VOORSPOED.
}

\author{
De tocht naar Madja-Kerta.
}

$\mathrm{Na}$ Sénapati's verheffing tot panembahan dient de priesterlijke wijding te volgen, Babad 102-3:

Sénapati zond per bode een brief naar Giri, om zekerheid te verwerven omtrent de voorspelling, destijds aan de sultan van Padjang gedaan.

Sunan Giri ontving het schrijven in openbaar gehoor en nodigde Sénapati uit, zich persoonlijk van de juistheid der voorspelling te overtuigen, door tegen Oost-Java op te trekken. Daarop volgde de voorspelling, waarvan de slotsom was : ,de heer wordt knecht, de knecht wordt heer. Het bewijs is er al in Padjang en Mataram."

Sénapati aanvaardde de uitnodiging en besloot naar het voorbeeld van de sultan in de maand Mukaram te vertrekken. $Z_{\text {ijn }}$ oom, dip. Mandaraka zou de adipati's van Pați, Demak en Grobogan Oostwaarts leiden, zodat ze niet in Padjang behoefden te verzamelen.

Zo bereikte het leger Djapan (Madja-Kerta), waar ook een Oost-Javaans leger verscheen. De pangéran van Sura-Baja voerde het aan, vrezende, dat Sénapati de onderwerping van alle OostJavaanse rijken beoogde. Deelnemers waren de bupati's van OostJava en Madura, een luisterrijke schare.

Doch ook kwam in Djapan een afgezant uit Giri, die de aanvoerders en hun prijaji's in zijn tijdelijk verblijf samenriep. Hij las zijn geestelijke zonen van Mataram en Sura-Baja een brief voor, waarin de sunan van Giri hun verbood te strijden, om bloedvergieten te voorkomen en de kleine man te sparen. Voorts legde hij hun een raadsel voor: „Kiezen jelui.... nu: inhoud of vat!” Pg. Sura-Baja koos de inhoud en liet Sénapati het vat, waarmede deze genoegen nam. Aan zijn teruggekeerde bode verklaarde sunan Giri : ,.... Het vat.... is het grondgebied, de inhoud.... de mensen. Wanneer de mensen de eigenaar van de grond niet gehoorzamen, worden ze natuurlijk verdreven." Sénapati had dus inderdaad het beste gekozen.

De Serat Kanḍa (597-608) levert geen belangrijke verschillen op:

Schriftelijk verzoekt Sénapati bevestiging zijner verheffing tot panembahan door zijn bode, de mantri Pangalasan, en verkrijgt die vlot. 
Daarop besluit hij de Oosthoek te gaan onderwerpen en trekt er met 6000 man, nevens zijn oudoom, heen. Doch de pangéran van Sura-Baja brengt daartegen een 40.000 man te velde, afkomstig van naburige regenten, en zendt eerst bericht van zijn voorgenomen tocht aan de sunan van Giri. De beide scharen legeren zich tegenover elkaar. Al spoedig brengen 40 santri's uit Giri een antwoordschrijven van de sunan en begeven zich tussen de linies. Daarop nodigen telkens twee santri's de beide partijen uit, in het midden samen te komen. Onder een gele pajong wordt dan de brief geopend en gelezen. De inhoud is een aanmaning tot vrede. Het raadsel luidt: „Welke van beide ... verkiest gij het eerst te genieten, de vruchten van den tegenwoordige tijd, of al wat... Java in de toekomende tijden zal opleeveren?" Sénapati kiest natuurlijk de toekomst. Daarop verzoent men zich en scheidt in vriendschap. Aan de terugkerende 40 santri's bevestigt de sunan Sénapati's juiste keuze.

In hoofdzaak stemmen dus Babad en Serat Kanda overeen. Om twee zaken is deze geschiedenis bijzonder opmerkelijk.

Vooreerst is de eerste geestelijke, tot wie Sénapati zich om bevestiging zijner nieuwe waardigheid wendt, de ver afgelegen priestervorst van Giri. Hij zoekt het dus niet bij geestelijke grootheden in zijn naaste omgeving, zomin bij Kudus als Adi-Langu, wier glans vermoedelijk door die van de Giriër overstraald werd. Sunan Giri schenkt hem zijn zegen op de benoeming tot panembahan en legt zich derhalve neer bij de achteruitzetting van Padjang.

Ten tweede slaagt panembahan Sénapati er in, een groot deel van Midden-Java, van Zuid tot Noord, te zijnen behoeve in beweging te brengen. Hiertoe behoort dus niet alleen het oude gebied van Mataram en wat ten Westen daarvan lag, maar ook streken, die pas sedert kort met het lot van dit gebied verbonden waren, zoals Padjang. Doch zelfs met Pați werden de verbindingen weer aangeknoopt. De man, die de hoofden ten Noorden van het Kenḍeng-gebergte tot samenwerken met Mataram en tot oprukken naar het Oosten wist te brengen, was de oude adipati Mandaraka, befaamd om zijn wijs beleid.

Wat het doel van de tocht, Oost-Java, betreft, dit moet zich reeds vóór, doch zo niet, dan toch ten gevolge van de gebeurtenissen in Padjang van Midden-Java hebben afgewend. Daar weigerde men dus voortaan bevelen uit Padjang of Mataram te ontvangen en het moest Sénapati's bedoeling zijn, de Oost-Javanen terug te brengen tot de vroegere gehoorzaamheid, waaraan Padjang hen gewend had. Wellicht 
hoopte hij dit doel met een enkele veldtocht, gesteund door het geestelijk gezag van Giri, te kunnen bereiken.

Indien hij zich dit had voorgesteld, dan heeft hij zich wel schromelijk vergist. De regenten van Oost-Java, onder leiding van de pangéran van Sura-Baja, waren op hun hoede en stuitten de Mataramse aanval in het dal van de Brantas bij Madja-Kerta, niet ver dus van het historische Madja-Pait. Mataram's eerste onstuimige stormloop op het Oosten van Java was mislukt.

Wat Madiun betreft, het ware ondenkbaar, dat Sénapati met zijn bondgenoten tot Madja-Kerta zou hebben kunnen doordringen met dit gewest als openlijke vijand in de rug. Het is dus zeker, dat op dat ogenblik Madiun nog niet van Midden-Java was afgevallen. Het komt dan ook nog niet onder de bondgenoten van de pangéran van Sura-Baja voor en pas het volgende jaar liep het naar het Oost-Javaanse verbond over.

Wat de datering betreft, het meest voor de hand ligt, dat deze tocht naar Madja-Kerta plaats vond in het jaar na de nederlaag van adipati Demak, dus in 1589 , zijnde het jaar vóór de slag bij Madiun, die wij in 1590 zullen moeten stellen.

Merkwaardig is het bericht in de Serat Kandia over het spoedig sterven van de sunan van Giri, enige maanden na zijn voorspelling aan Sénapati. De opvolger van deze sunan Parapén voerde slechts de titel van panembahan, aangezien het ontzag en de eerbied voor zijn persoon niet zo groot meer zouden geweest zijn, als voorheen. Daardoor verkreeg de pangéran van Sura-Baja groter vrijheid, om te doen en te laten wat hij wilde, wat zich o.a. uitte in belastingheffing.

De moeilijkheid hierbij is, dat Wiselius het einde van deze laatste sunan van Giri in 1587 stelt, terwijl wij voor het incident te MadjaKerta het jaar 1589 meenden te vinden. Voorshands houden wij ons aan het laatste jaartal, aangezien wij omtrent Wiselius' bronnen in het duister tasten. Evenwel is het tijdsverschil niet zo groot, dat het ons bijzonder verontrust.

Volgens Wiselius was sunan Parapén's opvolger, panembahan Kawisguwa, van 1587 tot 1614 aan het bewind.

Hageman meent de achteruitgang van Giri's invloed reeds aan de sultan van Padjang te moeten toeschrijven, wat zich moeilijk laat controleren. 


\section{Afval en verovering van Madiun.}

$\mathrm{Na}$ de mislukte tocht naar Madja-Kerta viel Madiun af. De Babad (104) vertelt hierover:

Pg. Sura-Baja zond een gezant, om een bupati in Warung (Blora) aan te stellen. Daar de grond aan Sénapati behoorde, wilde hij deze onderwerpen, anders zou hij geen toelating krijgen. Daarop onderwierp zich de bupati ; evenzo de omgeving. ,Zij, die zich verzetten, werden verslagen." Toen sloot Madiun zich bij de Oostelijke bupati's aan.

De Serat Kanḍa (609-11) meldt niets over Warung, doch deelt eenvoudigweg mede, dat Sénapati, ansluitende bij de beslissing van sunan Giri, afzag van de belasting van het eerste jaar, doch aanspraak maakte op die der volgende. Madiun's afval wordt geweten aan de jaloersheid van zijn regent, de jongste zoon van sultan Trenggana. Voor de aanval op Mataram verbond deze zich met Pana-Raga en riep schriftelijk de hulp der Oost-Javanen in.

Ofschoon zij vrede hadden gesloten, verlangden beide partijen strijd. Sénapati haakte naar de voorspelde opperheerschappij, die het gezag over Padjang inhield. De tegenstanders wilde de macht van de parvenu vernietigen, zoals men een vonk dooft door er water op te gieten.

Warung was een belangrijk strategisch punt. Als vooruitgeschoven post van Sura-Baja bedreigde het tevens Pați en Madiun. Waaraan Sénapati zijn aanspraken op dit gebied ontleende, wordt niet vermeld. Mogelijk in verband met de nabuurschap van Pați en Séla. Voelde Madiun zich bedreigd door Sénapati's verwerving van Warung? Er moeten meer factoren geweest zijn, die hem van deze opkomeling verwijderden.

Panembahan Madiun was de jongste zoon van sultan Trenggana van Demak, derhalve genaamd pg. Timur. Na de dood van zijn vader was hij door de vorst van Padjang meegenomen en aan diens hof opgevoed. Denkelijk bevond hij zich daar nog, toen pg. aria Panangsang een aanslag op het leven van zijn voogd liet plegen, aan welke, indien deze geslaagd was, hij zelve evenmin ontkomen zou zijn. Later werd hij door sultan Padjang over Madiun aangesteld (Babad 46, 105) en verkreeg toen waarschijnlijk de titel van panembahan Madiun of panembahan Emas ing Madiun (Sadjarah Dalem gen.175). Hij huwde met de dochter van pg. ad. Sabrang-Kulon ing Demak en verwekte 24 kinderen. Zijn schoonvader zou een zoon van Demak's eerste vorst geweest zijn en 
reeds tijdens het leven van zijn vader zijn overleden. Velen zijner kinderen sloten ook deftige huwelijken, zodat de panembahan van Madiun een zeer voornaam heer zal geweest zijn (vide Sadjarah Dalem gen.176).

Deze aristocraat moet de opkomst van Sénapati, die ten koste ging der beide vorstenhuizen van Demak en Padjang, met lede ogen hebben aangezien. De verwerving van Warung door de Matarammers kan de druppel zijn geweest, die de emmer deed overlopen.

Met de overgang van Madiun grensde het gebied van Sénapati's vijanden tot aan Padjang, zodat zijn gezag in onmiddellijk gevaar verkeerde. Dit gevaar steeg nog, toen zijn tegenstanders Madiun als punt van uitgang voor de aanval op Mataram gebruikten. Hierover is de Babad (104-6) zeer uitvoerig:

De verbondenen brachten een zeer groot leger te Madiun op de been. Sénapati, door een spion gewaarschuwd, riep het zijne bijeen en brak juist in de maand Mukaram op. Bewesten Madiun aan de Kali-Daḍung betrokken ze kwartieren, enkel door de rivier van de stad gescheiden.

Ziende, dat de vijandelijke troepen de zijne verre overtroffen, bedacht Sénapati met zijn oom een list. Adi-Sara, een schone hofdienares, zou schijnbaar onderwerping aanbieden, in de verwachting, dat de pan. Madiun zijn legers zou ontbinden. 40 DjajaTaka's torsten en begeleidden haar draagkoets. Niemand viel haar lastig, toen ze fraai uitgedost de linies passeerde.

Onaangediend verscheen zij voor de pan. Madiun, welke ontstelde. Na lezing van Sénapati's brief van onderwerping, nam hij deze aan. Zijn opgeroepen bupati's zond hij weer naar huis. Adi-Sara verzocht daarop het waswater van pan. Madiun tot drinkwater voor haar meester, en verkreeg het ook. De verrukte Madiuner nam Sénapati aan als zoon.

Volgens de Serat Kanḍa (612-17) trekt de pg. Sura-Baja met 70.000 man op en legert zich ten Oosten van de rivier. Sénapati weet slechts 8000 man bijeen te krijgen en schaart zich aan de Westzijde. Ook hier brengt de zending der niet bij name genoemde, welbespraakte vrouw een ommekeer te weeg bij pan. Madiun, die zijn krijgsvolk laat aftrekken.

Het gebruik van vrouwen in de politiek is bij de Javanen gans niet ongewoon. Dat Sénapati, de zwakste zijnde, tot list zijn toevlucht neemt, is begrijpelijk. Als gewoonlijk is de Babad meer schilderend en heeft b.v. alleen de waswater-anecdote.

De Babad (106-7) geeft een kort tussenspel, n.l. het tussentijds bezoek van Sénapati aan sunan Kali-Djaga te Adi-Langu, ter verwer- 
ving van het baadje kj. Gundil of Anta-Kusuma, een tovermiddel voor strijders, waardoor dezen niet getroffen worden. Daar dit een der vier grote rijks-pusaka's is geworden, blijkt uit dit ingelast verhaal, dat in de Serat Kanḍa ontbreekt, welke grote betekenis men aan de komende gebeurtenissen hechtte. Een bezoek aan sunan Kali-Djaga omstreeks die tijd is alleen al hierom zeer weinig waarschijnlijk, omdat deze vermoedelijk reeds gestorven was. Doch men kent de grote voorliefde van de Babad voor deze figuur, die ook daar optreedt, waar hij niet kan optreden.

Over de slag zelve verhaalt de Babad het volgende (107-8):

De volgende dag bemerkte Sénapati het vertrek van een deel der vijanden, terwijl het overschot weinig op zijn hoede was. Hij beval een aanval in 3 kolonnes, voor zonsopgang. Sénapati met het baadje $\mathrm{kj}$. Gundil, gezeten op de vos Puspa-Kentjana nam persoonlijk deel aan de hevige strijd. Tegen 9 uur werd het paard gedood, doch draafde nog tot 12 uur door, toen oom Mandaraka er opmerkzaam op maakte. Sedert mocht niemand uit zijn geslacht meer een vos berijden. Daarop nam hij zich voor, de kraton in te gaan.

De schrijver van de Serat Kanḍa (618-23), vermoedelijk een militair, is, zoals wel vaker, over de krijgsgebeurtenissen uitvoeriger:

Eerst tast Sénapati die van Pana-Raga aan, welke schimpende op de Madiuners, die hen in de steek lieten, moeten vluchten.

De volgende dag zal de strijd tegen de pg. Sura-Baja en zijn aanhang plaats vinden. Dezen steken de rivier over, waar Sénapati hen verwacht in een goede opstelling: pg. Mangku-Bumi op de linker-vleugel; pg. Singa-Sari met de Demakse troepen op de rechter; ad. Mandaraka met de adipati's van Pați en Padjang in het midden. Sénapati laat zijn centrum halt houden en de vleugels oprukken, terwijl hij zelve met 100 ruiters de overgestoken vijanden in de rug aantast. Daardoor wordt het ganse Oost-Javaanse heir vernietigd. De Matarammers plunderen daarna en rukken tegen de kraton op.

Het verslag in de Serat Kanḍa ziet er degelijker uit, dan het sprookjesverhaal in de Babad. Men zou haast menen, dat de schrijver van de Serat Kandia Livius' slag bij Cannae gelezen had.

Het verbod aan Sénapati's nazaten om vossen te berijden herinnert aan een dergelijk verbod, dat reeds eerder in de Babad (60) voorkomt.

$\mathrm{Na}$ deze zege met kris en piek behaalde Sénapati nog een overwinning 
op Amor's terrein, welke de Babad (108-9), belust op dgl. anecdoten, als volgt uitbuit:

Pan. Madiun was ontsteld over de nederlaag en zeide: „Ik had niet gedacht, dat dit de bedoeling van Sénapati was. Men kan hem met recht nektar en vergif (marta-wisa) noemen: uiterlijk nektar, innerlijk vergif."

Daarop vertrok hij met de zijnen naar Wira-Saba en liet slechts zijn dochter Retna-Djumilah achter, gewapend met de kris Gumarang. $\mathrm{Na}$ van een flauwte bekomen te zijn, kleedde de prinses zich als krijger met kris, pistool en werpspies. Zo verwachtte ze Sénapati in de binnen-kraton. Deze held bleek onkwetsbaar voor haar wapenen, zelfs voor een scheermes. Ten slotte werd zij door hem in zijn armen genomen en tot zijn gemalin gemaakt.

De Serat Kanḍa (623-25) voegt er nog de bijzonderheid aan toe, dat de strijd tussen de maagd en Sénapati 24 uur duurt.

Aan dit romantische verhaal hechten de Javanen groot gewicht en terecht. Door dit huwelijk werd de nieuweling Sénapati opgenomen onder de hoogste adel. $Z$ ijn verworven bruid was n.l. een kleindochter van Trenggana, laatste vorst van het zelfstandige Demak. Thans bestaan in de Vorstenlanden nog dansen, die de strijd tussen Séna-Pati en Retna-Djumilah verbeelden en waardoor de Babad-schrijvers zich mogelijk hebben laten inspireren. Men denke b.v. aan het pistool als wapen der schone maagd, welk uitheems wapen toch wel een zekere vertrouwdheid met de Europese sfeer veronderstelt.

De gedachten van panembahan Madiun over zijn tegenstander Sénapati lijken niet ver van de waarheid te zijn.

Een noodlottige invloed had het Madiunse huwelijk van Sénapati op zijn verhouding tot de verwanten in het Noorden, Babad 109:

Toen de dipati van Pati vernam van het huwelijk, was hij zeer ontstemd. Hij vroeg verlof, om huiswaarts te keren onder voorwendsel, dat zijn gebied gevaar liep. Sénapati wilde hem tegenhouden, doch vergeefs, hij wou toch naar huis en vertrok. Sénapati vreesde zijn afval en maakte zijn oom deelgenoot van zijn zorgen. Dip. Mandaraka was hierdoor ook onaangenaam getroffen.

In de Serat Kanda (626) staat het iets anders. Op de hofdag na het huwelijk gaat de adipati van Pați, de zoon van ki Pandjawi, zonder afscheid weg, gebelgd, omdat dit huwelijk gesloten wordt in een tijd van veel bloedstorting. Sénapati, de reden radende, laat hem gaan. 
Deze adipati van Patii is, gelijk boven reeds wordt vermeld, de zoon van kj. gedé Pamanahan's medestander ki Pandjawi, en wordt meestal adipati Pragola (I) genaamd. Zijn vader moet dus onderwijl gestorven zijn. De opgegeven redenen voor zijn breuk met Sénapati lijken onvoldoende. Blijkbaar vreesde hij de macht van Sénapati, die door de overwinning bij Madiun te overmatig groeide. Of mogelijk achtte hij zijn zuster, die met Sénapati getrouwd was, door dit Madiunse huwelijk achteruit gezet.

Deze breuk met Pați is nooit meer volkomen geheeld. $Z$ ij heeft geleid tot twee geweldige opstanden (1600 en 1627). Na de laatste was Paṭi een puinhoop.

Het jaartal, dat Babad Sengkala, Babad Momana en Raffles' Chronological Table eenstemmig voor deze gebeurtenis geven, is A.J. 1513, dus : A.D. 1591. Doch aangezien zij alle voor een stellig hierná volgend feit, n.l. de actie bij Kediri, het Javaans jaar 1512 (A.D. 1590) opgeven, moeten beide jaartallen waarschijnlijk verwisseld worden. Wij krijgen dus voor de slag bij Madiun 1590; voor de gevechten bij Kediri : 1591.

Het loont voorts de moeite na te gaan, hoe het verder de Madiuners gegaan is.

Van pan. Madiun's 24 kinderen vermeldt de Babad er slechts twee, t.w. de reeds genoemde Retna-Djumilah en mas Lontang, die later regent van Djapan zou worden (B.T.Dj. 111).

Retna-Djumilah huwde Sénapati en droeg als zijn gemalin de titel rd. aju Djumilah. Drie zonen schonk zij hem: rd. mas Djulig; rd. Bagus, later genaamd: rd. ad. Djuminah, en ten slotte tot panembahan verheven; rd. mas Kanitrèn, later: pg. ad. Marta-Laja ing Madiun.

De tweede is ons uit de Nederlandse bronnen bekend als pg. ad. Djuminah (d. J. V, 140 en 149) en is wellicht dezelfde als de kj. ad. Madiun, die elders vermeld wordt (d. J. V, 151). Hij nam deel aan het tweede beleg van Batavia in 1629. Waarschijnlijk hebben hij en zijn nakomelingen weer over Madiun geregeerd als passend verbindingslid tussen het Mataramse en Madiunse huis, daar hij een zoon van Sénapati en een kleinzoon van het laatste zelfstandige hoofd over Madiun was.

In 1669 wordt de dood van een dipati Madiun onder treurige omstandigheden in de Babad Sengkala vermeld en drie jaar later blijkt de plaats vacant te zijn, want dan is er even sprake van, om een zekere kj. Wiratmaka van Japara daar aan te stellen (d. J. VI, 186).

Daarnaast wordt nog als regent van Madiun genoemd een zoon van 
Sénapati's broeder pg. Mangku-Bumi, bagus Pétak. Het eenvoudigst lijkt mij, dat Sénapati eerst zijn neef bagus Pétak over Madiun aangesteld heeft, en dat pas later, toen zijn eigen zoon rd. ad. Djuminah oud genoeg was, deze in Madiun mocht opvolgen.

\section{De strijd met Pasuruhan.}

$\mathrm{Na}$ Madiun's val volgt een gewoonlijk zeer overschatte episode, de strijd met Pasuruhan, Babad 110-11:

De dipati van Pasuruhan voorzag een aanval van Sénapati en besloot zich te onderwerpen, waartoe hij reeds een geschenk gereed hield. Zijn onderhorige bupati Kanitèn nam evenwel op zich, tegen Sénapati een tweegevecht te voeren, waartoe hij inderdaad van zijn meester de opdracht kreeg.

Sénapati, dit vernemende, trok hem vanuit zijn pasanggrahan te paard tegemoet, donkerblauw gekleed, met 40 evenzo uitgemonsterde piekeniers, de Numbak-Tjemeng's, voor wier aanvoerder hij zich slechts uitgaf. De strijd ontbrandde en het geleide keek juichende toe. $\mathrm{Na}$ een gebed tot Allah wist Sénapati zijn tegenstander aan de knie te raken, waardoor deze uit het zadel gelicht, verdoofd neerviel. Ki Kanitèn werd daarna op een ongezadelde kreupele merrie, met een dik touw als teugel naar zijn heer in Pasuruhan teruggezonden, onder geleide der 40 Numbak Tjemeng's.

Deze deelde zijn veldheer mede, wie hem verslagen had, waarop hij zeide : „Als ik zo even geweten had, dat.... die met mij vocht, Sénapati was, zou ik niet hebben durven terugkeren; ik zou de dood verkozen hebben."

De dipati, hierdoor vertoornd, beval ki Kanitèn te onthoofden, doch de bijl brak. Daarom werd hem gesmolten lood in de keel gegoten, zodat hij stierf. De dipati beloonde daarna de 40 man van Sénapati en stuurde een bode met schatting aan hun heer ,als een teken van onderwerping en overgave van het rijk Pasuruhan."

Sénapati verheugde zich hierover en zei tot de bode: „....zeg ....dat ik meteen naar Mataram terugkeer, en dat je heer in zijn gebied bevestigd blijft. Maar wanneer er bevelen komen voor de Oost-Javaanse bupati's, laat hij die dan opvolgen.” Daarop keerde Sénapati naar Mataram terug.

De afwijkingen van de Serat Kanda (627-34) zijn de volgende:

Ad. Kanitèn stelt zijn heer voor, met 2000 onderhorigen Sénapati aan te tasten. Deze trekt de Pasuruhanner vanuit Madiun tegemoet. Eerst heeft een gewone veldslag plaats, waarbij de Matarammers de moed verliezen. De volgende morgen een tweegevecht tussen Sénapati en ki Kanitèn. Sénapati's paard krijgt een wond aan de kop en rent 
weg. Reeds heft het volk van Pasuruhan een gejuich aan, wanneer Sénapati terugkeert. Hij wondt Kanitèn aan de linkerdij met zijn piek kj. Plèrèd, die daardoor enigszins beschadigd wordt. Kanitèn valt ter aarde en eist de doodsteek. Sénapati laat hem evenwel achterste voren op de merrie zetten en onder geleide van 40 man terugbrengen. Het slot wijkt niet noemenswaard af. Het geschenk is in natura : rijst, herten, buffels en koeien, en wordt onder veel verontschuldigingen aangeboden.

De Babad is weer wat meer anecdotisch, de Serat Kanda wat meer militair, maar groot zijn de verschillen niet. Pasuruhan moet in die tijd een korte bloeitijd doorgemaakt hebben (vgl. Rouffaer in: Eerste Schipvaart II, 338 noot).

Dit avontuur van Sénapati is in de litteratuur opgeblazen tot de volledige verovering en inlijving van Pasuruhan bij het Mataramse rijk. Doch de stad wordt zo min aangevallen als bemachtigd. Het zendt wat schatting in natura en daarmede is Sénapati volmaakt tevreden. Onjuist is het daarom, deze plaats als een machteloze vazal van de Matarammer te beschouwen, daar het zich juist in de volgende jaren sterk ten koste van het naburige Balambangan uitbreidt.

$\mathrm{Ki}$ Kanitèn moet anders wel een bijzondere figuur geweest zijn. In de Babad Momana wordt onder A.J. 1432 (A.D. 1510) de „dadosipun Bupati Kanitèn” vermeld; in de Babad Sengkala eenvoudig: „Ing Kanitèn” en bij Raffles: „Era of Kanitèn”. Als wij deze gegevens pogen te combineren, zouden wij komen tot het begin van een nieuw, vermaard geslacht, waaruit dan onze ki Kanitèn zou stammen. Erg helder is het niet.

Wij verbazen ons intussen over een gevecht met Pasuruhan te lezen, terwijl Sénapati in Sura-Baja en Kediri nog niets te zeggen heeft. Daartegenover blijkt uit de Babad Sengkala, dat in die jaren de lieden van Pasuruhan soms ver van huis gingen. Voor A.J. 1501 (A.D. 1579) wordt daar gemeld, dat Keḍiri te gronde gaat, bevochten door de lieden van Pasuruhan, die in drommen oprukken. Waar deze mensen een dozijn jaren vóór het gevecht met ki Kanitèn zich nog van Keḍiri konden meester maken, daar behoeven wij ons over een ontmoeting van Sénapati met een troep uit Pasuruhan ergens buiten de muren van Madiun niet meer te verwonderen.

Wat het tijdstip betreft, kan dit gevecht volgens de Serat Kanda niet lang na de verovering van Madiun hebben plaats gevonden, daar Sénapati, Madiun verlatende, ki Kanitèn ontmoet. De vrij betrouwbare 
Babad Sengkala is het hiermede eens en vermeldt voor hetzelfde jaar 1513 (1591) de strijd bij Kali Ḍaḍung (Madiun) en Pasuruhan.

De Babad Sengkala geeft voor dit jaar ook nog een plundering van Djipang ,duk kabojong Djipang"; de Babad Momana vermeldt niets van die aard, doch Raffles heeft voor het jaar 1591: „The people of Jipang carried into captivity after the battle of Kalidádung, actions in Pasúruan and Pranarága”. Hageman geeft twee jaar later: „Djipang onder Mataram gekomen".

Dat er iets met Djipang moet voorgevallen zijn, doet wel een ander jaartal onderstellen, n.l. Babad Sengkala A.J. 1520 (A.D. 1598) : „Kala ambangun kita Djipang, tunggil warsa Padjang agilir nambut karjèng Djipang", d.i. dus de wederopbouw van Djipang, waarbij de Padjangers om beurten herendiensten verrichtten.

$\mathrm{Bij}$ de roof-en plundertochten, die het tijdperk na de verovering van Madiun kenmerkten, is dus ook Djipang blijkbaar het slachtoffer der Mataramse benden geworden.

\section{Sénapati in het Westen.}

Hoe en wanneer Mataram's macht zich in het Westen gevestigd heeft, is niet zeer helder. Wij zagen reeds, dat de volkshoofden van Bagelèn, de mantri's pamadjegan, op weg zijnde, om in Padjang hun hulde te bewijzen, de avonturier Sénapati als heer erkenden. De Babad vermeldt verder niets over deze streken tot op de vermaarde vlucht van MangkuRat I Tegal-Wangi, en wij dienen ons tot andere bronnen te wenden. Daar hebben wij vooreerst Jacob Couper's „Verhaal van het geslagt der Cherribonse princen, en tegenwoordigen Zousouhounang, en hoe verde die van Cheribon in den Sousouhounang gehouden zijn" (Dagreg. $1 / 10-1684)$.

Hij vertelt daarin, hoe de „Pangerang Senapattij ingh Mataram” zijn geluk willende beproeven, alle „sultans” gevangen nam, „die hij om hals liet brengen, zijnde en blijvende zoo meester van de geheel Oostcust Java". Dat zijn dus de bloedige oorlogen, die Sénapati in Noordelijke en vooral in Oostelijke richtingen heeft gevoerd.

Doch daarop wendde hij de blik naar het Westen, want hem ontbrak nog slechts de sultanstitel, „die hij sogt met bewilliging en toestemming van al het volcq en den Sultan van Chirribon". Te dien einde stuurde hij afgezanten naar de Tjerebonse heerser, met de uitnodiging naar 
Mataram te komen, en hem de sultanstitel te verlenen, of, indien dit onmogelijk was, hem die dan maar schriftelijk toe te kennen.

Doch de panembahan Ratu van Tjerebon zou zelve naar Midden-Java vertrokken zijn en Sénapati daar een titel geschonken hebben, die klonk als een.klok: sultan Abdul Kahar ibn Mataram. Met deze reis naar Mataram en sultansverheffing aldaar staat evenwel de Tjerebonse bron alleen. Sénapati heeft nimmer een sultanstitel gekregen, zelfs niet van de Tjerebonse vorst. Kennelijk is hier een vergissing in het spel met de reis van de Tjerebonner naar Mataram in 1636, toen er inderdaad sprake van geweest moet zijn sultan Agung (en niet zijn grootvader) met een ratu-titel te bedenken, hetgeen deze afsloeg (zie alle plaatsen hierover in de Haan's Priangan III par. 60). Overigens zijn de Tjerebonners er natuurlijk op uit, om de Mataramse grootheid van hun stad te laten uitgaan.

Doch hetgeen volgt, lijkt niet zonder betekenis : „Den Sultan Mataram (= Sénapati) ijet tot vergeldingh.... willende doen, zont een groot getal menschen den Panembahan (van Tjerebon) na, om met zijn believen een stad te bouren, gelijk is geschiet, die met een steenen muur van een ongemeene dikte wierd omtrocken, gelijck de overblijfselen daarvan nogh aanwijsen". Bovendien schonk hij enige stukken geschut.

En niet slechts waren de overblijfselen van deze bijzonder dikke muur in 1684 nog aanwezig, doch reeds in 1596 moet zij hebben bestaan, aangezien de berichtgever van de Eerste Schipvaert schrijft over „de stadt Charabaon, die seer fraeij met een dicke muer versterckt was”. Zowel in 1596 als in 1684 viel de dikte van de wal op.

Vóór 1596 moet dus deze muur voltooid zijn, anders kan het gerucht daarvan niet tot schipper Houtman en de zijnen doorgedrongen zijn. Dezen deden immers Tjerebon zelve niet aan en zijn ongetwijfeld door de Portugezen ingelicht (men lette op de uitgang van Charabaon!).

Valentijn, die eveneens een Tjerebons bericht opgevangen heeft, ofschoon hij Sénapati door de sultans van Demak en Padjang vervangt, deelt iets mede over de muurbouw (IV, 69): „Ontrent drie maanden daar na verschenen gezanten van beide deze Sulthans by den nieuwen Soesoehoenan (van Tjerebon), bragten van de strandvolkeren vyf of zes duizend man mede, en gaven last.. om een bemuurde stad hier te bouwen, die 800 vadem lang, en breed, en waar van de muuren 2 vadem dik, en 3 vadem hoog zouden zyn...."

Daarentegen schrijft de Babad Tjerbon, uitgegeven door Brandes en Rinkes (Verh. Bat. Gen. LIX, II 1e ged.) de muurbouw toe aan de sultan van Demak. In Zang XXVI slaat men de wali sunan Gunung 
Djati voor, patih van Demak te worden, doch hij weigert en wordt slechts pandita.... Geheel Java is nu bekeerd. $R d$. Sëpět een patukangan van Madja-Pait verfraait Demak.

De sultan van Demak leert nu nog bij Sunan Gunung Djati en bouwt voor hem de kuța Tjerbon en de kĕdaton aldaar met behulp, van de genoemde Raden Sěpět.

Het belangrijkste in deze mededeling lijkt mij niet zozeer het bouwheerschap van de Demakse sultan, als wel het verhaal omtrent de uit Madja-Pait afkomstige bouwtraditie, die in Demak en Tjerebon haar voortzetting vindt. De nog aangetroffen monumenten bevestigen deze mededeling, ook al is de Chinese invloed in Tjerebon sterk geweest.

Gezien de gang van de cultuur, n.l. van Oost naar West, lijkt het niet waarschijnlijk, dat Tjerebon vanuit het Zuiden tot de bouw van een muur is geinspireerd. De Mataramse overlevering maakt het trouwens niet aannemelijk, dat in Tjerebon het initiatief tot muurbouw zou zijn gekomen uit een gebied, waar zovele belangrijke bouwwerken op aansporing van vreemdelingen zijn tot stand gekomen.

Duidelijk is, dat volgens de overlevering de verhouding tussen Mataram en Tjerebon vriendschappelijk geweest is, en weinig pleit daartegen. Rijklof van Goens, die zijn indrukken een dertig jaar eerder dan Couper opdeed, verklaart ook (p. 358) dat omstreeks 1619 de Mataramse vorst „nae veel bloedstorten verwinner (is) gebleeven van 't geheele landt, excepto Jacatra, Bantham, Cheribon en Balambanghan". Tjerebon werd dus niet na een bloedige worsteling onderworpen. Daarmede had Sénapati zelfs "groote correspondentie en goede vreede" onderhouden (p. 357), wat hij op zijn sterfbed zijn zoon had aanbevolen, „quansuijs, omdat den Cheribonder vóór hem 't gelooff hadde aengenoomen ende een heijlige man was".

Inderdaad, in Tjerebon heersten nog steeds de afstammelingen van de heilige Sunan Gunung Djati, met welke Mataram in het midden der $17 \mathrm{e}$ eeuw in een goede verstandhouding leefde, zodat hun stamvader geredelijk als leermeester der Matarammers kon gelden.

Later is ook geen sprake van hevige rancune der Tjerebonners jegens hun Mataramse overheersers, ook al ging de vriendschap op den duur in onderwerping over en moesten de Tjerebonse vorsten zich noodgedwongen in Mataram vestigen. 


\title{
SÉNAPATI'S STRIJD OM DE LEIDING. TEGENSPOED.
}

\author{
Het overlopen der Kediriërs.
}

$\mathrm{Na}$ de verovering van Madiun heeft Sénapati geen grote, opzienbarende successen meer behaald. Het buitenland kreeg zelfs de indruk, dat zijn zaken achteruit gingen en dat de Mataramse oppermacht een voorbijgaande episode was.

Wij zullen deze geringe voorspoed wel dienen toe te schrijven aan het ontbreken der medewerking van Pați, dat zich na Sénapati's huwelijk met de Madiunse prinses had terug getrokken.

Een belangrijke versterking, meer naar hoedanigheid dan naar hoeveelheid, ontving Sénapati uit Keḍiri, Babad 111-12:

De meeste door Sénapati overwonnenen vloden naar Sura-Baja, b.v. de zoon van pan. Madiun, mas Tjalontang. Hij werd er schoonzoon van pg. Sura-Baja en bupati van Djapan (MadjaKerta). Ook in Wira-Saba werd een bupati aangesteld: rangga Premana. De Kedirische bupati, pg. Mas had 4 broeders: Sénapati van Kediri, Sara-Dipa, kéntol Djedjanggu en Karti-Masa. $\mathrm{Na}$ de dood van pg. Mas werden die 4 gepasseerd en een ratu Djalu over Kediri aangesteld.

De 4 broeders voelden zich gekrenkt en schreven aan Sénapati: ze wilden in zijn dienst treden. Hun afgezant heette Jakarti.

Sénapati, door dit nieuws zeer verheugd, beval pg. WiraMenggala naar Kediri te gaan, de overlopers tegemoet. Hij kreeg mee: de mantri's pamadjegan en de bupati's van Padjang, Demak en Djaga-Raga met hun troepen, en tg. Alap2 als raadsman. Ook de bode moest mee, doch terwijl Wira-Menggala, zodra Sénapati van Keḍiri zich bij hem gevoegd had, diende terug te keren, zouden de overigen de tocht naar Rawa voortzetten.

De Mataramse troepen legerden zich nu in Pakuntjèn, ten Westen van Kediri. Ook ratu Djalu maakte zich gereed. 's Nachts verlieten de afvallige groten (totaal een 200 zielen) heimelijk de kota. Toen ratu Djalu hen opmerkte, zette hij hen na en haalde hen in bij Krakal. Een gevecht ontbrandde, de Matarammers schoten te hulp. Na een korte, hevige strijd sloeg ratu Djalu op de vlucht en sloot de poort der vesting achter zich. De Matarammers achtervolgden hen niet. Slechts Sénapati van Kediri's schoonzoon werd gewond. Wira-Menggala keerde daarop naar 
Mataram terug met Sénapati Keḍiri, en te Djaga-Raga hielden zij halt.

Onderwijl trok tg. Alap2 voort naar Rawa, dat hij uitplunderde. Daarna vervoegde hij zich ook in Djaga-Raga, waarna zij samen naar Mataram opbraken. De buit werd aan Sénapati getoond, de nieuwe bondgenoten voorgesteld. Dezen kregen een woning en mooie kleren. Sénapati Kediri werd door de vorst als zoon geadopteerd en ontving 1500 bouwgrond, zijn broeders evenredig.

De Serat Kanḍa (634-44) is in hoofdzaak gelijk, met enige opmerkelijke leemten, toevoegingen en afwijkingen. De reden van Sénapati Keḍiri's ontevredenheid wordt niet vermeld. Sénapati belooft hun in Mukaram hulp en zendt dan niet Wira-Menggala, doch zijn zoon pg. Purbaja. Deze krijgt in Mataram 1000 man mede en moet in Padjang drie dagen wachten, aleer de troepen daar marsvaardig zijn. Kediri krijgt op verzoek 1000 man versterking uit Sura-Baja met nog krijgsvolk der Mantja-Nagarase bupati's. Pg. Purbaja ageert vanuit KertaSana. Alvorens uit te rukken houdt de adipati van Kediri hofdag, waarvan Sénapati Kediri wegblijft, ziekte voorwendende. Een onbeslist gevecht beëindigt de nacht, gedurende welke Sénapati Kediri met 100 der zijnen deserteert. De volgende morgen zet ad. Keḍiri hen met 500 man achterna, doch dezen worden met Mataramse hulp afgeslagen. 's Avonds belanden ze veilig in Purbaja's kamp. Nadat met nog 1000 man Rawa geplunderd is, verzamelt men zich in Djaga-Raga. Sénapati laat zijn zoon in Randu-Gunting afhalen en zendt kleren voor Sénapati Kediri en de zijnen. Deze wordt 's vorsten zoon en krijgt 1000 tjatjah's. Hij belooft de Oosthoek te vermeesteren.

Dit verhaal in zijn beide lezingen is zo uitvoerig, bevat zoveel namen en overtollige bijzonderheden, dat we er een bijzondere graad van historiciteit aan dienen toe te kennen. Verschillende deelnemers aan deze gevechten hebben ook nog lang daarna een belangrijke rol gespeeld. Zo werd Sara-Dipa later tot bupati bevorderd onder de naam van Marta-Laja. Als zodanig streed hij in 1617 nog tegen Pasuruhan. Tg. Alap-Alap trad in 1627 op bij de strijd tegen Pați. Hun mondeling getuigenis kan de eerste optekenaars dezer feiten dus bekend zijn geweest.

Dat pg. Sura-Baja een aantal bolwerken tegen de verwachte Mataramse aanvallen poogt op te werpen, is volkomen redelijk. Alle drie de genoemde plaatsen liggen in het Brantas-dal, de eerstvolgende verdedigingslinie, nadat Madiun verloren was gegaan.

De Matarammers behalen dan ook slechts voorbijgaande successen. 
Er wordt wat gevochten, zij helpen ontevredenen overlopen, zij plunderen de een of andere plaats. De grootste winst is, dat twee dezer overlopers voortreffelijke helpers blijken te zijn: Sénapati van Keḍiri en Sara-Dipa, al. Marta-Laja.

Zoals wij reeds zagen viel deze actie in het jaar 1591.

\section{Sénapati Kediri als bouzomeester.}

Niet onmiddellijk betreedt Sénapati Keḍiri het oorlogsveld, Babad 112:

Sénapati wilde Mataram omwallen, waartoe hij witte en rode baksteen bezigde, de kuta Batjingah. Sénapati Kediri had er toezicht op. In 1509 was de tweekleurige muur gereed. Schietgaten ontbraken echter, daar de bouwmeester trots opmerkte: "Als er vijanden komen, trek ik hun tegemoet buiten de stad...." Toen Sénapati daarna sprak over de voorzegde val en verwoesting van de kraton door de Oost-Javanen, merkte zijn veldheer op: „Zo lang ik leef, zal dit wschl. niet gebeuren, want ik neem op mij, de Oost-Javanen te verdelgen."

Op de laatste woorden na ontbreekt dit verhaal in de Serat Kanḍa. Het kan op een historisch feit teruggaan: muurbouw, welke, gelijk wij reeds zagen, in het oude Mataram nog al eens moet hebben plaats gevonden. Het jaartal 1509 (A.D. 1587) komt, gelijk wij opmerkten, op de kelir van de eerste poort der moskee voor en zal dus daaraan wel ontleend zijn. Voor deze muurbouw was ruimschoots gelegenheid in de drie jaren rust, welke de Serat Kanḍa (645) na Sénapati Keḍiri's overlopen vermeldt.

De Babad Sengkala stelt de bouw van een ,kița bata putih” in A.J. 1514 (A.D. 1592); de Babad Momana in ditzelfde jaar de ,marnate lampahing Kraton”; Raffles in het volgende jaar de "Construction of Kótah Batu Púteh”. Wij hebben dus de keuze tussen 1592 en 1593.

Dertig jaar na dit laatste jaartal werd Sénapati's kraton voor het eerst door een Nederlander, dr. De Haan, bezocht en beschreven. Wij vinden zijn verslag in het niet door De Jonge in deel 5 van zijn Opkomst van het Nederlandsche Gezag gepubliceerde gedeelte van zijn Journael, hetwelk wij daarom dienen na te lezen in no. 992 van het Koloniaal Archief.

Op 30 Juni 1623 verliet dr. De Haan de kraton Karta van sultan Agung en volgde met zijn bereden gezelschap eerst een „cleene weg”. Daarna kwam hij op een „schoone breede wegh" uit, langs welke hij 
de ,stadt Mataram” bereikte. Na daar doorheen gereden te zijn, naderde men een tweede stad. De afstand tussen beide steden bedroeg „omtrent een musquetschot" en er stroomde ook een rivier tussen. Hun namen luidden: „Cota Saba (en) Cota Dalm ofte Mataram, alwaer des Conincks vader eertijts gewoont heeft". Genoemde steden waren zeer uitgestrekt en werden door een ontelbare menigte bewoond. Er liepen „seer schoone en breede weeghen" doorheen en men vond er verschillende pasars. De muren waren omstreeks 24 tot 30 voet hoog en 4 voet dik, en daarbuiten stroomde nog een „rivier” (wschl. een natte gracht).

In de ene stad woonde kj. dip. Mandura-Redja, en in de andere kj. dip. Upa-Santa. Laatstgenoemde had zijn woning vlak bij de ,poort, in 't uijtvaren", dus waar dr. De Haan de tweede stad verliet, om naar Pingit door te reizen.

De Jonge's onderstelling, dat wij hier met vestingen te maken zouden hebben, welke Karta moesten verdedigen, lijkt ten minste onvolledig. Meer voor de hand ligt, dat wij hier met de kraton van Sénapati te maken hebben. Behalve, dat de naam Mataram ons in die richting wijst, pleit hiervoor, dat 's konings vader, d.i. pan. Krapjak, er zou gewoond hebben. Daar wij van deze vorst geen verhuizing kennen, bewoonde hij dezelfde kraton als zijn voorganger Sénapati. Derhalve is het door De Haan aanschouwde Mataram of Kuṭ Dalem het huidige kuta Gedé, Sénapati's vroegere kraton, thans zijn graf. De grote, brede, druk begane weg, langs welke onze gezant in deze plaats kwam, moet dan de weg van kuṭa Geḍé naar Ima-Giri wezen, welke inderdaad door kleinere vanuit Karta te bereiken is.

Echter, de Haan onderscheidt naast een kuṭa Dalem nog een kuta Djaba, dus behalve een binnen-kota, nog een buiten-stad. Beiden liggen op een musketschot ongeveer van elkander en worden gescheiden door een rivier. De ene doet voor de andere in afmetingen en volksrijkdom niet onder. De binnenstad meenden wij reeds te vinden, doch waar ligt de buitenstad?

Tussen Karta en Pingit, punt van vertrek en aankomst van dr. De Haan, stromen slechts twee rivieren, t.w. de kali's Gadjahwong en Tjodé. Eerstgenoemde doet kuṭa Geḍé aan, doch men krijgt niet de indruk, dat hij twee afgezonderde steden of wijken van elkander scheidt. Dit is wèl het geval met de diepe en brede kali Tjodé, daar deze tussen twee aanzienlijke steden loopt, t.w. het reeds genoemde kuṭa Gedé en de huidige hofstad Jogja-Karta. Tussen beide stadscomplexen is ook duidelijk op de kaart een open ruimte te onderkennen, 
die thans wel wat wijd lijkt voor een musketschot, doch die eertijds kleiner kan geweest zijn.

De huidige kraton zou dus op dezelfde plek liggen, als waar eertijds een stichting van Sénapati lag, die toen kuṭa Djaba genaamd werd, terwijl kuṭa Geḍé kuṭa Dalem heette. Inderdaad komt men ook, na Jogja-Karta gepasseerd te zijn, vrij spoedig te Pingit aan. Dit ligt een kleine K.M. ten Westen van de bekende Pal Putih, welke zich weer juist in de as van de tegenwoordige kraton bevindt.

Het nauw verband tussen deze binnen- en buitenstad vindt voorts zijn uitdrukking in het feit, dat beide stadsdelen door een broederpaar bewoond werden, t.w. de zonen van pg. Mandura, die in Gambiran begraven lag (Babad $121 \&$ vlg.). Dit Gambiran lag ten Westen van kuṭa Geḍé en is thans een der kampongs van deze plaats. Deze pg. Mandura was weer de zoon van Sénapati's raadsman adipati Mandaraka. Daar de rijksbestuurder geacht werd de vorst te verdedigen en zijn woonplaats, de kepatihan, derhalve vaak op een plek lag, waar men de vijand verwachtte, is er misschien toch wel iets voor De Jonge's onderstelling omtrent vestingen te zeggen.

Doch het verwonderlijke blijft, dat Sénapati's residentie blijkbaar nog een voorstad bezat. Was deze kuṭa Djaba, later Jogja-Karta, soms het kuṭa Batjingah uit de Babad, waaraan Sénapati Kediri nog gewerkt heeft?

Sénapati Kediri sneuvelt bij Uter.

Dat Sénapati Mataram in de verdediging gedrongen was, bewijst wel de geschiedenis van het sneuvelen van zijn veldheer, Sénapati Kediri, Babad 112-13:

De Oost-Javaanse bupati's kwamen te Madiun bijeen met het doel, Mataram te veroveren. Aanvoerders waren de dipati's Gending en Pesagi. De eerste trok met de helft der troepen ten Noorden van de Lawu, de andere met de rest ten Zuiden daarvan.

De vorst, door spionnen ingelicht, verzamelde al zijn troepen. Zoons, verwanten en bupati's waren voltallig bijeen. Bijna was hij zelve ook gegaan, doch Sénapati Kediri vroeg verlof voor hem het leger te mogen aanvoeren. In Tadji splitsten zich de Matarammers; pg. Purbaja voerde de Noordelijke, Sénapati de Zuidelijke troepen aan. Alleen de laåtsten komen nog ter sprake. Bij Uter ontmoetten elkander de legers. Sénapati streed man tegen man met zijn oom, dip. Pesagi, zijn persoonlijke vijand. Beiden sneuvelden gelijktijdig. De Mataramse sentana's, hierover verwoed, vielen hevig aan en vaagden de Oost-Javanen weg. $Z \mathrm{ij}$ keerden terug met krijgsgevangenen en Sénapati's lijk, dat op bevel van de vorst te Weḍi begraven werd. 
Alle krijgers van het zegevierende leger werden beloond en sommigen bevorderd, t.w.: Sara-Dipa werd bupati Marta-Laja ; ki Djedjanggu dip. Supanta; ki Karti-Masa Sara-Dipa. De nog onvermelde ki mas Sari werd dipati van Demak enz.

De Serat Kanḍa (645-60) geeft als zo vaak hierover veel meer militaire bijzonderheden en cijfers. Het leger der Oost-Javanen telt 50.000 man, dat hunner tegenstanders 20.000. Sénapati Keḍiri krijgt van zijn vorst een gouden baḍong (borstsierplaat). In Padjang wordt het leger opgesteld, spionnen uitgezonden. Van een splitsing ten Noorden en Zuiden van de Lawu is niet duidelijk sprake, wel misschien van twee legers, nl. dat van pg. Purbaja (in het Zuiden) en dat van Sénapati Kediri, Mangku-Bumi c.s. met de hoofdmacht (in het Noorden?), die echter nauw samenwerken en de vijanden tussen elkander verpletteren. Op de vlucht der Oost-Javanen vindt het heroïsche tweegevecht plaats tussen Sénapati Keḍiri en zijn oom, ad. Pesagi, waarin beiden vallen. $\mathrm{Na}$ de slachting der vijanden en de plundering van hun kampement vieren de Matarammers de ganse nacht luidruchtig feest. Mangku-Bumi zendt twee boden, om de vorst van het sneuvelen van zijn veldheer op de hoogte te stellen; deze beveelt het lijk in Wedi te begraven. Daarop volgen beloningen in klederen en de bovengenoemde bevorderingen.

Nadat ad. Mandaraka gevraagd heeft, of hij nog Oost-Java zal aantasten, antwoordt de vorst, dat het nu nog geen tijd is, doch dat zijn nakomelingen dit zullen ondernemen.

Wederom zijn de hoofdzaken gelijk, de onderdelen verschillend. Het Mataramse leger weet een gevaarlijke aanval, op het hart des rijks gericht, met moeite af te slaan en aan weerszijden sneuvelt een aanvoerder. Hoe bedenkelijk de toestand was, blijkt wel daaruit, dat de Oost-Javanen zich van Madiun konden meester maken. Een herovering door de Matarammers wordt wel niet gemeld, doch zal niet achterwege zijn gebleven.

Terwijl we van Sénapati Kediri's oom noch vroeger noch later iets vernemen, treffen we naderhand een bupati Gending aan als ondergeschikte van een Mataramse grote, pg. Puger van Demak. Deze bupati Gending stookt zijn meester op tegen diens broeder pan. Krapjak (Babad 118). Wellicht vindt dit raadsel zijn oplossing in de Nederlandse mededeling, dat Demak het tijdens zijn verzet tegen Mataram het met Sura-Baja, dus de Oost-Javaanse vijanden hield. 
Zowel de Babad als de Serat Kanda onderscheiden een Noordelijke en een Zuidelijke troep, waarvan er een door 's vorsten broeder pg. Purbaja wordt angevoerd, doch daarmede is dan ook de ganse overeenkomst in krijgszaken ten einde.

Wat de plaatsen betreft: Uter is òf Wana-Giri òf Uteran, dat bij Madiun ligt. In het verhaal past het laatste beter, mede omdat de slag ook wel die van Djati-Sari genoemd wordt (Babad Momana A.J. 1517). Daar er bij Uteran in het Madiunse tevens een Djati-Sari gevonden wordt, zal de slag dus bij Madiun hebben plaats gevonden, dat toen misschien tegelijkertijd heroverd is. Weḍi, Sénapati's Keḍiri's begraafplaats, ligt bij het heiligdom Tembajat.

De voorspellende woorden van Sénapati in de Serat Kanḍa kan men als een opgeven der Oostelijke veroveringspolitiek beschouwen, doch tevens als een in zijn mond gelegde voorspelling omtrent de veroveringen van sultan Agung. Hierbij zal de tot Marta-Laja gepromoveerde Sara-Dipa nog een belangrijke rol spelen.

Wat de datering betreft, de Babad Sengkala geeft voor A.J. 1515 (A.D. 1593): „Duk prang Pahuter tunggal warsa pagut prang Djatisari”. Dit betreft dus het samenvallen van twee dichtbij elkander plaats vindende gevechten, zoals bij de slagen van Jena en Auerstadt, Waterloo en Belle Alliance. De Babad Momana stelt de slag op A.J. 1517 (A.D. 1595). Raffles heeft in zijn Chronological table voor hetzelfde jaar: Battles of Jatasari \&c fought by Senapáti. Bij Hageman ontbreekt het jaartal.

De strijd had dus in 1593 of 1595 plaats, zijnde 2 of 4 jaar na het overlopen der Kediriërs, dat wschl. in 1591 plaats vond. Nu meent de Serat Kanda, dat tussen dit overlopen en Sénapati's dood drie vredesjaren liggen. Dit klopt dus vrij aardig.

\section{De aanvallen op Tuban.}

$\mathrm{Na}$ de slag bij Uter en het sneuvelen van Sénapati Kediri ( \pm 1594$)$ vermelden Babad en Serat Kanḍa niets meer dan de grote opstand van Pati uit 1600. De jaartal-babads verraden evenwel, dat er toch wel wat belangrijks in dat zevental jaren voorgevallen is, al kunnen wij niet steeds het gewichtige ervan beseffen door de kortheid der mededelingen.

Zo hebben wij voor 1594 een verandering of verwisseling in WanaKerta (= Padjang?). Slaat dit soms op een verwisseling van personen, b.v. het optreden van de laatste Padjangse vorst pg. Benawa Jr.? Wij kunnen slechts gissen. 
Voor 1596 meldt de Babad Momana een geschil tussen de regenten van Oost-Java, verdeeld in een gele en zwarte partij, toegestaan door sunan Giri. Heeft dit misschien betrekking op de strijd van Pasuruhan tegen het hindoeïstische Balambangan? Dit zou zeer zeker door sunan Giri toegejuicht zijn.

Voor 1598 en 1599 heeft de Babad Sengkala weer belangrijk nieuws, t.w. voor beide jaren een Mataramse aanval op Tuban. Deze moet gefaald hebben, want de stad was bij de jaarovergang 1598-99 nog in volle fleur en de bewoners noemden hun koning de machtigste vorst van Java.

Daar juist in die tijd de Nederlanders van de tweede Schipvaert naar Oost-Indië deze havenstad aandeden en er in hun journalen een beschrijving van gaven, zullen wij de zeldzame gelegenheid benutten, om door het oog van een buitenstaander een blik te werpen in het Java van Sénapati, al is het dan nog niet in echt Matarams gebied.

Volgens Begin ende Voortgangh (III, 9) was „Tuban ... een fraye koopstadt", doch wat wij er van horen, draagt een sterk feodaal karakter. De stad is ,rondsom bemuert en met houten poorten beset... seer net op haer maniere ghemackt".

Volgens de bewoners was hun vorst „de machtighste Koningh van gantsch Iava", die, zo nodig, binnen 24 uur enige duizenden manschappen te velde kon brengen, te paard en te voet. De rest der beschrijving is bijna geheel aan die koning en zijn hof gewijd. Deze „was een dick vet man, van middelbare stature", de Nederlanders welgezind. Hij droeg een zwart fluwelen jasje met wijde mouwen, een doek om 't (onder)lijf en een kris aan de riem. Dit wapen bezat een gouden heft, waarop een „duyvelstronie”. In het huisken op zijn statie-olifant zat de vorst met gekruiste benen en had de beleefdheid de Nederlanders aan het strand tegemoet te rijden, om hen daarna in zijn "paleys” te begeleiden. Dit gebouw was zeer groot en telde vele vertrekken. De muren waren van baksteen en de vloer was geplaveid met estriken. De toegangspoorten leken over het algemeen nauw en laag. Er vóór stonden de olifanten onder afdaken, 13 stuks, w.o. één heel groot en woest beest. Verschillende afdelingen werden de bezoekers vertoond: de bagagiekamer, het hanenhuys, het papegayenhuys, het hondenhuys, het eendenhuys, het vrouwenhuys (waar de Nederlanders vier ,ghetroude wyven" en wel 300 bywyven te bewonderen kregen). Daarbij passeerde men steeds enige poorten, onder welke een, ,daer een dick man niet wel door en soude komen". (p. 11). Ten slotte kwam de 
„kamer van de Tortelduyven, zynde zyn slaep-kamer”, en de „peerdestallen", zeven in getal.

Uit de beschrijvingen en zeer gebrekkige afbeeldingen krijgt men de indruk, dat de Tubanse gebouwen op die te Bantam geleken. W. F. Stutterheim (De Kraton van Majapahit p. 110-111) noemt dit het „Majapahit-type” of „Balische type”, omdat men dit thans nog slechts op Bali aantreft. Het is de ,open balé- of pendapa-constructie op een hoog soubasement, al dan niet met gordijnen of wandvlakken afgesloten" (p. 110 sub 2).

Dit is dus wel een duidelijk blijk van het voortleven der MadjaPaitse cultuur in de Pasisir.

De vorst, die dit laat-Madja-Paitse paleis bewoonde, voerde het liefst een gesprek over krijgszaken, als hij niet met zijn dochtertje speelde, dat een slavin naar hem toebracht.

De handel werd door de adel bedreven. Als echte lieden van hoge geboorte hadden zij daarnaast ,grooten sin ende genoeghte in peerden”. Hierop volgt een uitvoerige beschrijving hunner opgetuigde paarden en van het ,tornoy-spel” (p. 13). De schrijver woonde zulk een spel „op de Marckt" bij, van veel Edelluyden... tot een vereeringhe van onse Koopluyden" gegeven. De koning was er ook, soms te paard, dan weer op zijn olifant. Elk edelman bereed meerdere paarden. Zij maakten niet de indruk van naarstige kooplieden, integendeel. Zelf voerden zij niets uit, doch zonden hun schepen door de ganse Archipel heen, tot in de Philippijnen toe. Verlieten zij hun woning, het was niet zonder een statig gevolg van 10 of 12 dienaars, welke hun betelgerei meedroegen.

Zo waren de Tubanners dus half koopman, half edelman, evenals de Bantammers.

\section{Ondergang van Kali-Njamat.}

Gelukkiger dan tegen Tuban moet Sénapati tegen het rijk JaparaKali-Njamat geweest zijn.

Onder A.J. 1521 (A.D. 1599) meldt de Babad Sengkala: „,beḍahé Kali-Njamat". Toen zou het rijk van Japara pas te gronde zijn gegaan.

De koningin was toen vermoedelijk reeds lang niet meer aan het bewind, want in 1593 was er een koning aan de regering, die zich in dat jaar van het eilandje Bawean of Lubak meester maakte en daar 
een ,ridder" met 100 man plaatste (Beghin ende Voortgangh 1646 p. 95).

Vijf jaar later regeerde er nog steeds een koning. Toen passeerde er de vloot van de eerste Schipvaert en de Nederlanders vernamen, dat Djapara weliswaar slechts door palissaden omgeven was (dus niet door stenen muren, zoals vele andere zeehavens), doch nog steeds, sedert véle jaren een koning had, ,die seer machtigh is, soo te water als te lande". In 1599 moet diens macht een einde genomen hebben, ofschoon Djapara's roem niet zo spoedig uit de herinnering verdween.

Immers in 1613 is er nog wel in de Nederlandse geschriften sprake van de ,coninghen van Japara ende Coutis” (= Kudus), ook al wordt er tevens aan toegevoegd, dat zij "beyde onder den Mataram staen” (d. J. IV, 15), van welke zij bevelen ontvangen. In 1615 is de gewone titel bij de Nederlanders dan ook gouverneur geworden, in tegenstelling tot het hoofd van Sura-Baja, dat men tot het bittere einde (in 1625) koning zal blijven noemen (d. J. IV, 58).

De Nederlanders wisten toen nog uit de Portugese historie, dat in Djapara ,eertyts den stapel van de negotie plach te wesen, ... dat doen ter tyt geen ander Coninck noch plaetse dan Japara voornemelyck vermaert ware, ende alle andre plaetsen van Java tot syne devotie stonden" (d. J. IV, 53).

Misschien dateert nog uit die gulden koningstijd het hoge ambt van „kjai demang Laksamana" (= admiraal), dat wij in de Nederlandse brieven van 1622 tot 1634 vermeld vinden (d. J. IV, 296, 297, 304, 305, 314 ; V, 39, 51, 175, 192, 209, 216). Wij troffen dit ambt vermoedelijk reeds aan bij De Couto in 1574 in de verbasterde en afgekorte vorm "Quilidamâo" (kjai demang) en in de Sadjarah Bantěn voor het jaar 1580 als kjai demang Laksamana van Japara (p. 37-39).

Een stoffelijke herinnering aan het vroegere koningschap te Djapara was het oude „koningshof”, gelegen op de plek van de huidige kabupatèn. Nicol. de Graeff achtte het ,gantsch onaangenaam gebouwd”, terwijl A. Bogaert in zijn Historische reizen (p. 450) meende, dat het meer op een doolhof, dan op een paleis geleek. Het bestond uit talrijke stenen en houten gebouwen, en allerlei gedierte, zoals olifanten, waren er te aanschouwen. Deze laatste diersoort moet wel sterk de indruk van een vorstelijke woning gewekt hebben. Op het einde der $17 \mathrm{e}$ eeuw is het afgebroken en vervangen (Babad 235).

1) In 1678 schijnt het ambt, waarvan een bijzonder prestige uitging, hersteld te zijn (Corte beschrijving etc. Ms. Kon. Inst. H 73, p. 14). 
Kort voor Sénapati's dood vond eindelijk de lang gevreesde afval van het verwante Pați plaats, B.T.D. 113-16:

Niettegenstaande de pogingen zijner familie, wilde de dipati van Pati in opstand komen. Daarom zond hij een bode naar Mataram, om het bestuur over alle dorpsgronden ten Noorden van het Kenḍang-gebergte te verzoeken, zo mede 100 piekpunten met passende schachten. Sénapati stond alles toe, behalve de schachten, wat oorlog betekende. Mandaraka was er diep van onder de indruk.

$\mathrm{Na}$ de terugkeer van zijn bode beval dip. Pati de grens te overschrijden en alle dorpelingen ten Noorden van het Kendenggebergte te onderwerpen. Allen onderwierpen zich, behalve Demak, dat zich binnen zijn muren wapende.

Toen ad. Pați (Pragola) genoeg krijgers had, trok hij op tegen Mataram en liet zijn troepen onderweg plunderen. Ad. Padjang waarschuwde Mataram, waarop Sénapati de kroonprins uitzond met order, slechts bij noodzaak geweld te gebruiken, opdat de zaak in der minne geschikt zou worden. De kroonprins trok naar Prambanan; het Patische leger naar Kemalon, waar het rustte en verder marcheerde. De kroonprins met de dragers der waardigheidstekenen trok alleen vooruit. Toen Pragola hen zag, werd hij verlegen en geërgerd. Hij wenste de vader van de prins te ontmoeten, om zich met deze in kracht en onoverwinnelijkheid te meten.

De kroonprins, driftig geworden, stak meermalen met de piek naar zijn oom, zonder deze te wonden. Pragola stootte zijn neef met het achtereinde van zijn piek van zijn paard. Deze werd naar Prambanan gebracht en Pragola hield halt, verschanste zich bij de Dengkeng in een benteng van klapperstammen.

Toen Sénapati aan zijn gemalin, oudere zuster van Pragola, vertelde, dat haar broeder zijn neef met een piek gestoken had, antwoordde zij: "In dat geval heb ik er vrede mee, dat hij gedood wordt, want dan is hij slecht."

Sénapati trok er nu zelve op uit, te paard. Te Prambanan werd overnacht. Kort na middernacht vertrok men weer. Bij de benteng van Pragola hief men een geschreeuw aan en sloeg op het bekken ki Bitjak, dat een dreunend geluid gaf. Mandaraka slaagde er in, met zijn kris $\mathrm{kj}$. Tjuli de verschansing van klapperstammen in drieën te delen, zodat Sénapati te paard kon binnenrijden. Pragola vluchtte, terwijl de Dengkeng door een vulkanische modderstroom buiten zijn oevers trad.

Toen Pragola in Pați aankwam, ontbood hij de naburige bupati's, die zich snel in slagorde schaarden. De achtervolgende Matarammers vielen aan en versloegen hen. Velen verdronken in een overstromende rivier. 
„Het was niet bekend, of de dipati van Pați dood was of nog leefde."

De overeenkomst met de Serat Kanḍa $(660-669)$ is verrassend. Slechts begin en slot zijn anders. Het ultimatum van Pați ontbreekt, evenals de verdediging in Pați. Wij aanvaarden de kortere lezing als de oorspronkelijke, mede omdat het bandjiren van de rivier van Pați een herhaling lijkt van de overstroming der kali Dengkeng. De aanval op Pați zelve zal dus niet hebben plaats gevonden.

De strijd tussen Mataram en Pați was in zekere zin een broederstrijd. Op de goede onderlinge verhouding kort voor de breuk wijst het verhaal van rd. Rangga's bezoek aan zijn oom, de dipati. van Pați. Deze ruwe zoon van Sénapati vertoont daar een van zijn sterkste staaltjes van krachtpatserij (Babad 100).

Behalve neven waren Sénapati en Pragola ook nog zwagers. De eerste had de zuster van de laatste gehuwd. Des te pijnlijker voelden de latere Matarammers het als een verwijt, dat hun de schuld van Pragola's dood kon verweten worden. Vandaar al de pogingen in het bovenstaande gedeelte, om zich van deze schuld vrij te pleiten. Het pleidooi is drieledig: $1^{\circ}$ het is niet eens zeker, of Pragola wel dood is; $2^{\circ}$ zijn eigen daden bewijzen zijn schuld; $3^{\circ}$ zijn bloedeigen zuster vond, dat hij maar gedood moest worden. Het zou ons daarom ten zeerste verwonderen, als hij niet door de Matarammers om het leven was gebracht.

De kroonprins, pg. Adipati Anom is ongetwijfeld de latere pan. Krapjak. Men kan niet zeggen, dat zijn sterkste zijde hier belicht wordt. Hij blijkt zich niet te kunnen beheersen tegenover zijn vasthoudende oom, die Sénapati's list, om hem met een zacht lijntje mee te tronen, wel degelijk doorziet.

Ki Bitjak is het bekende bekken. Als het een krachtig geluid geeft, betekent dit voorspoed.

Aannemende, dat het Mataramse leger niet naar Pați is doorgemarcheerd, verbaast het ons niet, wanneer wij Pragola I rustig zien opgevolgd door zijn zoon Pragola II.

\section{Sénapati's dood.}

Over Sénapati's sterven is de Babad (116-17) zeer kort:

Voor zijn dood gaf de vorst toestemming, dat zijn zoon Djolang hem als vorst zou opvolgen, hoewel hij nog jong was. Overtreders dezer beschikking werden met Allah's toorn bedreigd. Mandaraka en Mangku-Bumi moesten hem installeren. 
Nadat Sénapati drie jaar vorst geweest was, werd hij ziek en stierf. Men begroef hem ten Zuiden van de moskee aan het voeteneinde van het graf van zijn vader.

De Serat Kandia (670-72) zegt hetzelfde, doch drukt nog duidelijker uit, dat de kroonprins, hier Mangku- Nagara geheten, reeds enige maanden te voren voorbestemd is, om op te volgen.

Sénapati heeft dus vóór zijn dood gezorgd, dat de erfopvolging op regelmatige wijze zou plaats vinden. De titel van de kroonprins is in de $18 \mathrm{e}$ eeuw steeds Mangku-Nagara.

Dat enige oudere familieleden de trooncandidaat tot vorst verheffen komt in de 17 e en 18 e eeuw regelmatig voor. Een en ander zal deze vlotte en rustige erfopvolging begunstigd hebben.

Gezien Sénapati's postume naam Séda ing Kadjenar, moet Sénapati te Djenar bij Sragen overleden zijn, hetgeen Raffles bevestigt.

\section{Datering van Pati's opstand en Sénapati's dood.}

Voor de bepaling van Sénapati's sterfjaar bezitten wij een uitstekend hulpmiddel in de gelijktijdigheid van een zonsverduistering. De Babad Sengkala geeft n.l. voor het Javaanse jaar 1523 (A.D. 1601) op: De dood van panembahan Sènapati, de verhuizing van dip. Puger naar Demak en een zonsverduistering.

Prof. D. Brouwer, directeur van de Sterrewacht te New Haven, deelde mij mede, dat er op 30 Juli 1601 een totale zonsverduistering plaats had, „waarvan het totaliteitsgebied net Noord-Java raakte. Het is zeer wel mogelijk, dat die zonsverduistering in Midden-Java totaal was. In elk geval was het daar bijna het geval...". Aldus prof. Brouwer, die als bron opgaf: Oppolzer, Canon der Finsternisse. Wien 1887.

Hageman en de Babad Momana stellen Sénapati's sterfjaar eveneens in 1601, doch niet Raffles, die voor Sénapati's dood het Javaanse jaar 1521 geeft (A.D. 1599) en de zoneklips op 1522 stelt (A.D. 1600). Dit laatste is, naar wij hierboven zagen, onjuist.

Bovendien hebben wij nog steun aan een Nederlands bericht. Pan. Krapjak stierf kort na het vertrek van de Gouverneur-Generaal P. Both uit Japara op 29 Sept. 1613, dus ongeveer in de maand October 1613. Volgens de Babad (121) had hij toen 12 jaar geregeerd. Dit brengt ons dus al weer tot 1601 , hoewel Oct. 1601 wat te laat zou wezen.

De opstand van Pați wordt in de Babad één jaar voor Sènapati's 
dood gesteld. Voor het eerste geeft de Babadschrijver n.l. het foutieve jaartal A.J. 1551, voor het tweede het al even onjuiste A.J. 1552. Het verschil van één jaar is in dit verband het belangrijkste.

In de jaartallenlijsten worden beide feiten niet genoemd, tenzij wellicht in de Babad Sengkala, die voor A.J. 1522 (A.D. 1600) geeft: „Pedjahé Dipati Mesir, pinedjahan éndjang”. Is deze dipati van Mesir soms gelijk te stellen met de dipati van Pați? Misschien wel!

Prof. Pijper ontwikkelde eens de hypothese, dat de Moslimse Javanen in de streek om de berg Muria het heilige land en omgeving hebben willen herkennen. Mekka ware dan terug te vinden in Demak, naar welke beide plaatsen immers bedevaarten worden ondernomen. Staat een zevenvoudig bezoek aan de zeer heilige moskee in Demak niet gelijk met een bedevaart naar de Kaäba van Mekka?

Medina met het graf van de Profeet staat dan gelijk met Adi-Langu, waar sunan Kali-Djaga de dag des Oordeels verwacht.

Kudus, een der zeer weinige plaatsen op Java met een Arabische naam, staat voor Jeruzalem, dat de Arabieren Al Kuds noemen.

En in dit verband zou Pati best Mesir (= Egypte) genoemd kunnen worden. 


\section{SAMENVATTING.}

Pogen wij thans kort samen te vatten, hetgeen wij op onze onderzoekingstocht tegenkwamen.

Ten aanzien van Sénapati's voorouders was onze oogst vrij schaars. Slechts zijn vader, kjai geḍe Mataram vermochten wij als historische figuur te handhaven.

Ook zijn rol in de grote strijd tussen Padjang en Djipang bleek hoogst twijfelachtig te wezen. Hieruit volgt, dat de vestiging in Mataram moeilijk het gevolg kon zijn van de toekenning van dit gebied wegens in de strijd tegen aria Penangsang bewezen diensten. Mataram moet met geweld veroverd wezen.

Vaste grond krijgen wij eigenlijk pas onder de voeten bij de dood van Séna-Pati's vader. Daarná vertoont onze held neigingen tot zelfstandigheid, die bij zijn heer in Padjang bezorgdheid opwekken.

Mogelijk in samenwerking met de afstammelingen van een vroeger Padjangs heersersgeslacht, verheft Séna-Pati de vaan des opstands, rukt tegen zijn heer op en verslaat deze te Prambanan. De vorst van Padjang sterft daarop onder verdachte omstandigheden, doch Sénapati aarzelt, om op de leeg geworden zetel plaats te nemen.

Een Demaks tussenspel volgt, door Sénapati behoorlijk uitgebuit. Met de Padjangse pretendent verovert hij de kraton voor de tweede maal. Hoewel hij aan Padjang slechts een schijnbestaan gunt, waagt hij het nog niet, de vorstelijke titel te aanvaarden. Wel poogt hij door bemiddeling van de Girische priestervorst zich van Oost-Java meester te maken, doch voorlopig eindigt dit met een mislukking. Zelfs Madiun valt af.

De laatste moeilijkheid weet Sénapati schitterend te boven te komen. Door list vernietigt hij de Madiunse heerschappij en huwt een Madiunse prinses, welk vorstenhuwelijk de eeuwen door vermaard zal blijven. Doch dit huwelijk verwijdert tevens van hem Pați's geslacht, dat, als verwanten (?) hem tot dusver trouw had bijgestaan.

Daarom kan Sénapati sedertdien minder belangrijke successen boeken, hoe vermaard ook het incident met Pasuruhan in de overlevering moge zijn geworden.

De tocht naar Kediri verschaft hem slechts enige bekwame veldheren, 
niet deze plaats zelve. Evenmin vermag hij Tuban te vermeesteren. Slechts een strook tot aan de Noordkust, die Japara en Demak bevat, wordt Mataram's blijvend bezit.

Van de nood des rijks getuigt ook de openlijke afval van Pați, welks heerser zelfs tot Prambanan weet door te dringen, doch het ten slotte aflegt.

Wanneer de grote aanvoerder eindelijk de ogen sluit, is wel MiddenJava van Zuid- tot Noord-kust onder het Mataramse gezag gebracht, doch Oost- en West-Java laten zich daaraan nog maar weinig gelegen liggen. De grondslagen voor het bijna gans Java omspannende gezag van zijn kleinzoon, sultan Agung, zijn evenwel gelegd.

Zie daar in het kort de slotsom, waartoe wij meenden te moeten komen. 


\section{JAARTALLENLIJST 1546-1601.}

1546 Oorlog van het Moslimse Demak tegen Panarukan. Dood van sultan Trenggana.

1549 Pg. aria Panangsang laat de susuhunan van Prawata vermoorden.

1550 le expeditie der ratu Kali-Njamat tegen Malakka.

1558 Nederlaag van pg. aria Panangsang van Djipang(?).

1559 Jaartal in de moskee van Kali-Njamat.

1564 Dood der Atjehse gezanten te Demak.

1566 Jaartal op de poort bij het graf van sunan Bajat.

$1572 \mathrm{Kj}$. geḍé ing Sura wijkt naar Palembang uit vrees voor Padjang.

1574 2e expeditie der ratu Kali-Njamat tegen Malakka.

1578 Stichting van Kuța Geḍé. Padjang verovert Wira-Saba.

1580 Francis Drake bezoekt Balambangan.

1581 Sultan Padjang's reis naar Giri, waar hij bevestigd wordt door sunan Prapèn.

1584 Dood van kj. geḍé Pamanahan (Mataram).

1587 le Verovering van Padjang door Sénapati. Sultan Adi-Widjaja sterft. Jaartal op de moskee van Koța Geḍé.

1588 2e Verovering van Padjang. Ondergang van Demak. Sénapati wordt panembahan.

1589 Tocht van Sénapati tegen de Oost-Javaanse regenten te Madja-Kerta.

1590 Verovering van Madiun. Sénapati huwt Retna-Djumilah. Pați trekt zich terug.

1591 Overlopen van Sénapati Keḍiri.

1592 Muurbouw te Mataram.

1594 Slag bij Uter. Sénapati Kediri sneuvelt.

1596 Pasuruhan geraakt in oorlog met Balambangan.

1598 le Aanval der Matarammers op Tubań.

1599 2e Aanval op Tuban. Ondergang van het zelfstandige Djapara.

1600 Opstand van Pați. Pragola I verdwijnt.

1601 Sénapati sterft te Djenar. Zonsverduistering (30 Juli 1601). 


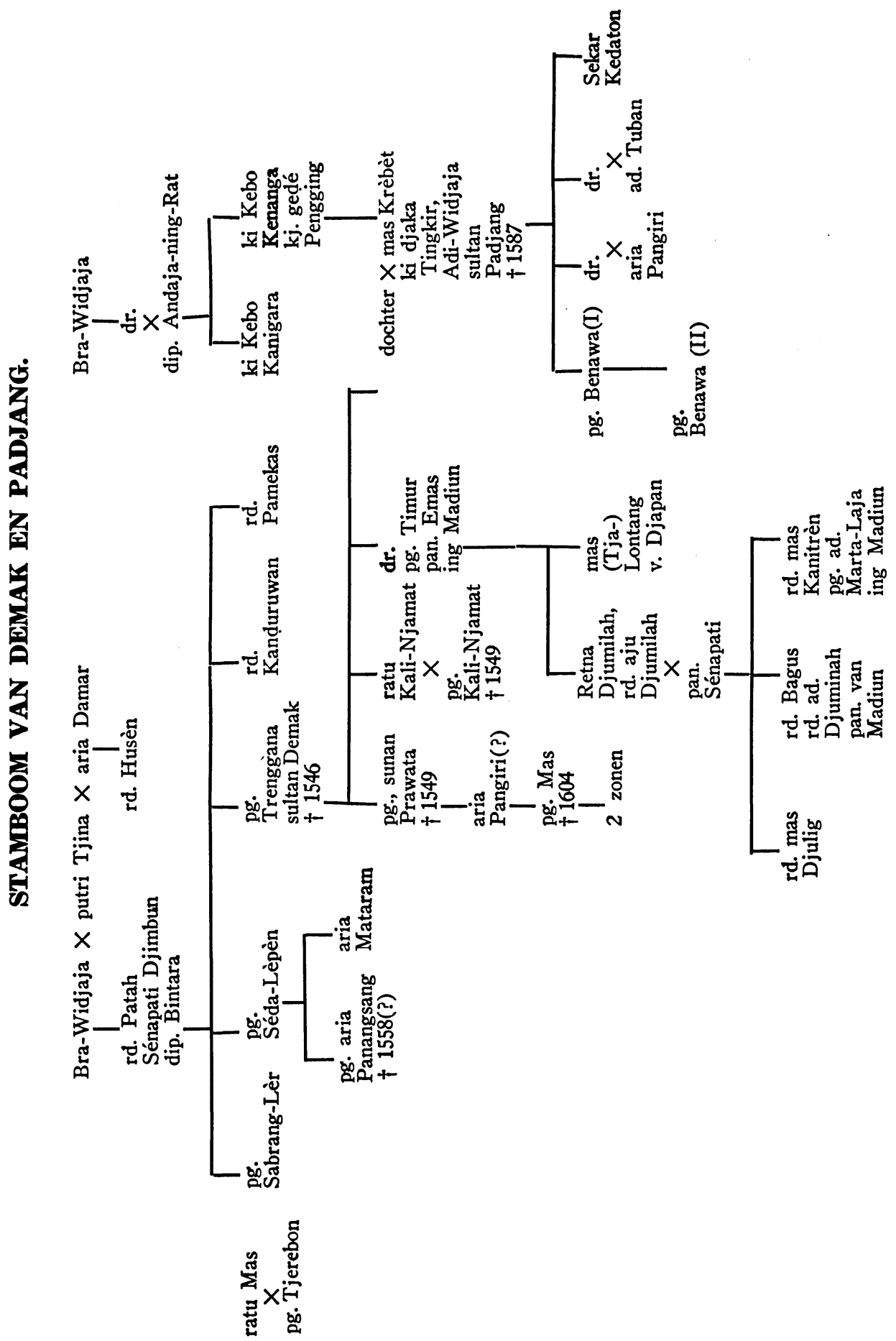




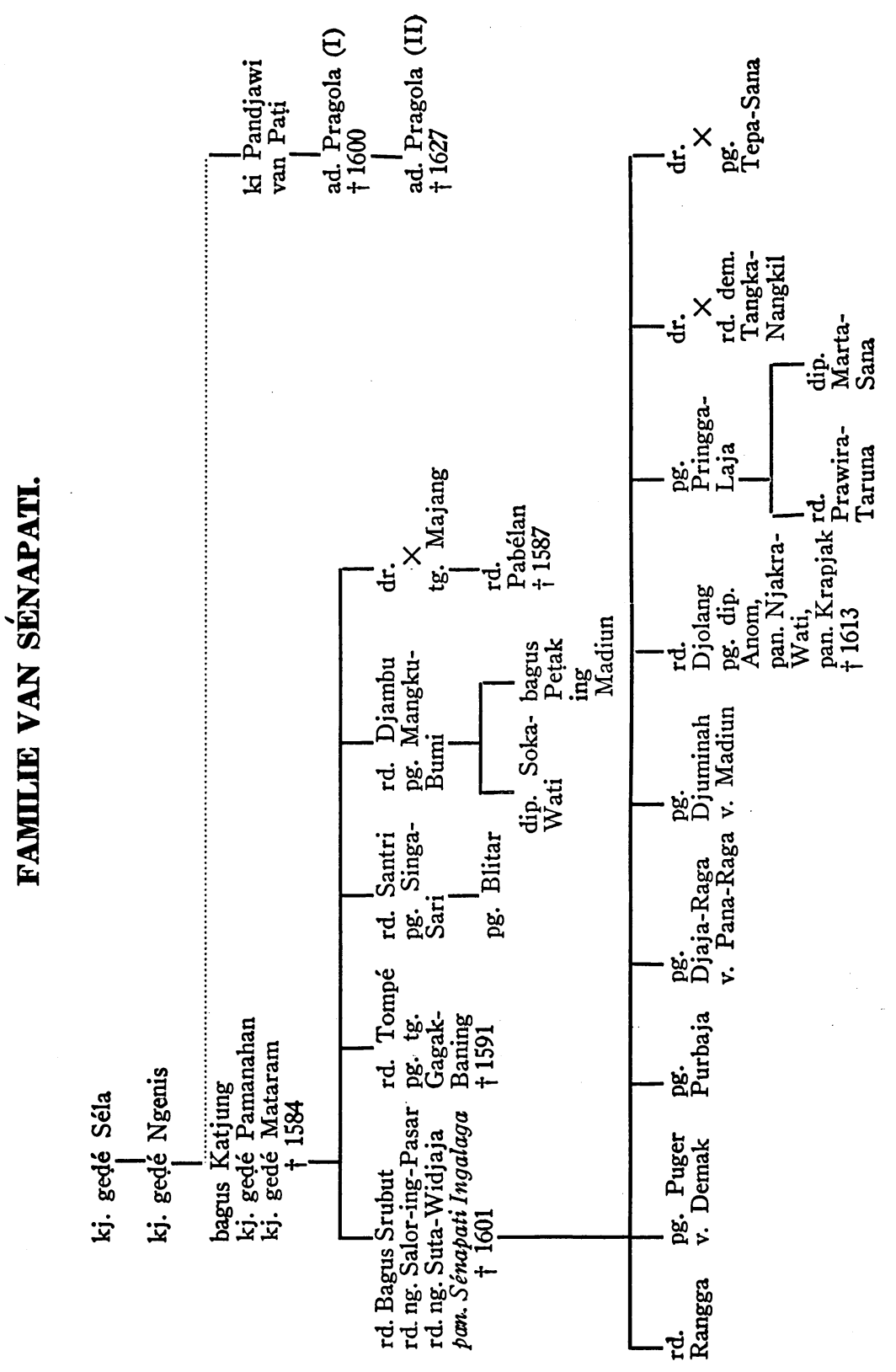




\section{BIBLIOGRAPHIE.}

\section{Javaanse bronnen.}

In handschrift:

Soerjanagara, Pg. Arja. Babad Sangkalaning Momana. Ms. K.B.G.

Babad Sengkala. Afschr. v. h. Bijbelgenootschap 87 (XIII). Ms. K.B.G. 608 Br. Sadjarah Regen Soerabaja. Ms. K.B.G. Br. 474.

Serat Kandia. Ned. Vert., beginnende met het verhaal van Adji Saka. 4 dln. Ms. K.B.G. no. 540.

\section{Gedrukten :}

Babad Pasir, volgens een Banjoemaasch Handschrift. Met vert. van J. Knebel. Verh. K.B.G. LI 1e st. Bat.-'s-Hage 1898.

Babad Tanah Djawi, in proza. Jav. geschiedenis... tot... 1647 der Jav. jaartelling. In ... opdracht v. h. Kon. Instituut... naar de uitgave van J. J. Meinsma ..., vertaald door W. L. Olthof. 's-Grav. (1941) (afgekort: Babad).

Babad Tjerbon. Verh. K.B.G. LIX ii le ged.

Cense, A. A. De kroniek van Bandjarmasin. Santpoort 1928.

Djajadiningrat, Hoesein. Critische beschouwing van de Sadjarah Bantěn. Bijdrage ter kenschetsing van de Jav. geschiedschrijving. Haarlem 1913 (afgekort: Sadj. Bant.).

Edel, J. Hikajat Hasanoedin. Meppel 1938.

Padma-Susastra (Ki), Sedjarah Dalem pangiwa lan panengen... Sam. 1902 (afgekort: Sadj. Dalem).

Pararaton (Ken Arok), of het boek der koningen van Tumapel en van Majapahit, uitgegeven... door J. L. A. Brandes. 2e dr. bew. door N. J. Krom... 's-Grav.-Bat. 1920.

Verh. Bat. Gen. LXII 1920.

Prawirawinarsa (rd.) \& Djajengpranata (rd.a.), I. Babad alit... Welt. 1921. Serie... Volkslectuur no. 577.

\section{Europese bronnen.}

\section{Boekwerken :}

Begin ende Voortgangh van de Ver. Ned. Geoctroyeerde O.I. Compagnie. Vervattende de voornaemste Reysen... I. Veerthien Voyagien. II... twaalf Voyagien... A'dam 1646. $2 \mathrm{dln}$.

Berg, C. C. De Middeljavaansche historische traditie. Santpoort 1927.

Bruin, C. de. Reizen over Moskovië, door Persië en Indië... Amsteldam ... 1719.

Coen, Jan Pz. Bescheiden omtrent zijn bedrijf in Indië, verz. door H. T. Colenbrander. 's-Grav. 1919-23. 5 dln. Uitg. Kon. Instituut.

Couto, Diogo de. Da Asia... Decada IV-XII. Lisboa 1778-88. 10 tomos.

Crawfurd, J. History of the Indian Archipelago... Edinb.-Lond. 1820. 3 vols.

Dagh-Register gehouden int Casteel Batavia... 1663, 1668, 1676. Bat.-'s Hage 1891-1903 (afgekort: D.).

Filet, P. W. De verhouding der vorsten op Java tot de N.I. regeering. 's-Grav. 1895. 
Haan, F. de. Priangan. De Preanger-regentschappen onder het Ned. bestuur tot 1811 ... 4 dln. Bat. 1910-12. Uitg. K.B.G.

Hageman Jcz., J. Handleiding tot de kennis der geschiedenis. aardrijkskunde, fabelleer en tijdrekenkunde van Java. Bat. 1852. 2 dln.

Hoëvell, W. R. v. Reis over Java, Madoera en Bali in ... 1847 ... Amst. 1849-54. $3 \mathrm{dln}$.

Jonge, J. K. J. de. De opkomst van het Ned. gezag in Oost-Indie... dl. I-X. 's-Grav.-Amst. 1862-78 (afgekort: d. J.).

Kartini, Rd. Adj. Door duisternis tot licht... Sem.-Soer.-'s-Grav. 1911.

Kern, R. A. De verbreiding van den Islam. In: Gesch. v. N.-I., onder leiding van F. W. Stapel. dl. I. Amst. 1938.

Krom, N. J. Hindoe-Javaansche geschiedenis 2e herz. dr. 's-Grav. 1931. Uitg. Kon. Inst.

Krom, N. J. Inleiding tot de Hindoe-Javaansche kunst. 2e herz. dr. 's-Grav. 1923. 3 dln.

Palmer van den Broek, W. Gesch. v. h. vorstenhuis van Madoera, uit het Jav. vertaald. T.B.G. XX 1873 , p. $241 \& 471$.

Pigeaud, Th. Javaansche Volksvertoningen. Bijdrage tot de beschrijving van land en volk. Bat. 1938.

Oudheidkundig Verslag 1930. Uitg. K.B.G. Bat. 1931. Oudheidkundige Dienst in Ned.-Indië.

Pinto, Fern. Mendez. Les Voyages Advantvrevx. Trad. du Port. par B. Figuier. T. 3e. Paris 1830 .

Pires, Tomé. Suma Oriental. London 1944. 2 vols. Hakluyt Society. Sec. series. nos. LXXXIX \& XC.

Poerbatjaraka, Rd.Ng. Pandji-verhalen onderling vergeleken. Band. 1940. Bibliotheca Javanica. Uitg. K.G.B.

Raffles, Th. St. The History of Java. London 1817. 2 vols.

Rapport van de Commissie in Ned.-Indië voor oudheidkundig onderzoek op Java en Madoera. 1910. Uitg. K.B.G. Bat.-'s-Grav. 1911.

Schipvaert (De eerste) der Nederlanders naar Oost-Indië onder Corn. de Houtman 1595-97. dl. I-II. 's-Gravenhage 1915-25. Werken... Linschoten-vereeniging VII \& XXV.

Schoel, W. F. Alphabetisch register v. d. administratieve... en adatrechtelijke indeeling van Ned.-Indië. dl. I : Java en Madoera. Bat. 1931.

Stutterheim, W. F. A Javanese period in Sumatran History. Surakarta 1929.

Stutterheim, W. F. De Kraton van Majapahit. 's-Grav. 1948. Verh. Kon. Inst. VII.

Valentijn, Fr. Oud en Nieuw Oost-Indie... Dordr.-Amst. 1724-26. 5 dln. (afgekort: Val.).

Veth, P. J. Java... historisch. 2e dr. I. Oude Gesch., II, Nieuwe Gesch.... Haarl. 1896-98. 2 dln. (afgekort: Veth).

Winter, C. F. Javaansche Zamenspraken. 3e dr. Amst. 1882.

\section{Handschriften.}

Corte Beschrijving van het Noord-Oostelijk gedeelte van Java's voortgang. Ned. Ms. Kon. Instituut. No. H 73.

Schrieke, B. O. J. Studiën over vorst en rijk op Oud Java. Ms. bewaard op het Kon. Instituut voor de Tropen.

\section{Tijdschriftartikelen.}

Bosch, F. D. K. Het Lingga-Heiligdom van Dinaja. T.B.G. LXIV 1924, p. 227-85. 
J. L. A. Brandes, Arya Penangsang's rechten en pogingen tot herstel daarvan. T.B.G. XLIII 189.

Coen, Jan Pz. Vertoogh van den staat der Ver. Nederlanden in... O.-Indien. Kron. Hist. Gen. te Utrecht. Utr. 1855.

Goens, R. M. v. Reijsbeschrijving van den weg uijt Samarang nae... Mataram (en) Corte beschrijving van 't eijland Java ... B.K.I. IV 1855 (afgekort : v. G.)

Graaf, H. J. de. Het Kadjoran-vraagstuk. Djawa XX 1940.

Graaf, H. J. de. De reis van Mangku-Rat IV naar Mataram, T.B.G. LXXXIII 1949, p. $340-69$.

(Gijsels, Artus). Grondig Verhaal van Amboyna. 1621.

(Gijsels, Artus). Verhaal van eenige oorlogen in Indië. Beide uit het Arch. v. Hilten. Kron. v. h. Hist. Gen. te Utrecht. 27e Jrg. 1871. Utr. 1872.

Hageman, Jczn., J. Algemeene Geschiedenis van Java, van de vroegste tijden af aan tot op onze dagen. Indisch Archief. Tijdschrift voor de Indiën. le en 2e Jrg. dl. I-IV 1850-51.

Neyens, M. De geheimzinnige klok. T.B.G. LXXVI 1936, p. 81-96.

Oorspronk van de eerste heerschappye van de Javaanse regeringen op het eijland Groot Java (door H. v. d. Horst) opgesteld wyt de oude Jav. schriften ende verhaalen. Biäng-Lala. Ind. Leeskabinet IV dl. I Bat. 1855, p. 262-81.

Pigeaud, Th. Alexander, Sakènḍèr en Sénapati. Djawa VII 1927, p. 321-61.

Poensen, C. Mangkubumi. Ngajogjakarta's eerste Sultan (n.a.v. een Jav. Hs.) B.K.I. LII 1901, p. 223-361.

Roo de la Faille, P. de Studiën over Lomboksch Adatrecht. Adatrechtbundel XV: Bali en Lombok.

Roo de la Faille, P. Uit den Palembangschen sultanstijd. Feestbundel K.G.B.... 1928. d1. II.

Rouffaer, G. P. Voorwoord bij: De val van de kraton van Padjang door toedoen van Senapati ( \pm 1586 ) volgens de Babad Tanah Djawi. B.K.I. L 1899, p. 284-89.

Rouffaer. G. P. Wanneer is Madjapahit gevallen? Het tijdperk van godsdienstovergang (1400-1600) in de Maleische Archipel. 1e bijdr. B.K.I. L 1899, p. 111-99.

Rouffaer, G. P. Een duistere plaats van Java's staatkundige toestand tijdens Padjang ... opgehelderd. Album-Kern 1903, p. 267-74.

Wessels, C. De eerste Franciscaner-Missie op Java ( \pm 1584-1599) ... Studiën N. Reeks. 62e Jrg. 113e dl. 1e halfjr., p. 117-26.

Wiselius, J. A. B. Historisch onderzoek naar de geestelijke en wereldlijke suprematie van Grisse op Midden- en Oost-Java gedurende de $16 \mathrm{e}$ en $17 \mathrm{e}$ eeuw. T.B.G. XXIII 1876, p. 458-509. 


\section{ALPHABETISCH REGISTER.}

\section{Enige afkortingen:}

$\begin{array}{ll}\text { ad. } & \text { adipati } \\ \text { ag. } & \text { ageng } \\ \text { dip. } & \text { dipati } \\ \text { g.g. } & \text { gouverneur-generaal } \\ \text { kdj. } & \text { kangdjeng } \\ \text { ng. } & \text { ngabéhi }\end{array}$

Abdul Kahar ibn Mataram, sultan: 115. Abdullah, maulana: 81.

Adi (sunan) : 29, 51, 77.

Adi-Baja (nj. ag.) : 5 .

Adi-Langu: 21, 28, 105, 108, 130.

Adipati (kj.) : 103 .

Adipati (Sang): 33 .

Adipati Anom (pg.) : 128.

Adi-Sara: 108.

Adi-Widjaja, sultan of vorst van Padjang: $22,27,28,30,62,85,91$.

Agung (sultan) van Mataram: 1, 3, 12, $13,41,48,60,88,89,115,123,132$.

Alap-Alap (tg.) : 117, 118.

alcatief : : kleed 63 .

Alexander de Grote: 74, 88.

Al-Kuds: = Jeruzalem 130.

Allah : 72, 73, 75, 76, 78, 79, 82, 85, 93-95, $112,128$.

alun-alun ( $=$ voorplein) : 94, 95.

Amboina, Ambon: 36, 61.

Andajaningrat van Pengging: 16.

Anḍap Tulis: 50.

Angrok (kén) : 89.

Anta-Kusuma (bloem): 109.

Arabië: 99, 100.

Archipelago (Indian) : 84.

Aria (pg.) van Demak: 24.

Aria (pg.) van Bantam: 35 .

Atjeh(-ers): 34, 35, 68.

Babad Banju-Mas: 64.

Babad Meinsma: 3.

Babad Padjadjaran: 74.

Babad Pasir: 74.

Babad Sengkala: 4, 24, 30, 43, 54, 61, 62 , $64,65,87,89,97,111,113,114,119$, $123,124,129,130$.

\author{
nj. njai \\ pan. panembahan \\ pg. pangéran \\ rd. radèn \\ rg. rangga \\ tg. tumenggung
}

Babad Sengkalaning Momana: 4, 12, 54, $64,97,111,113,114,119,123,129$.

badong: = borstsierplaat 123 .

Bagelèn: 114.

Bagus (rd.): = Sènapati 22, 111.

Bagus (rd.) $:=$ de latere rd. ad. Djuminah 111 .

Bajat (of Tembajat): 81 .

Bajat (sunan): 81.

Balambangan: $24,55,56,67,113,116$, 124.

Baléga: 58.

Bali, Baliërs: 31, 37, 56, 61, 67, 94, 125.

balé : = hal 125 .

balé kentjur: 85 .

Banda: 37.

Bandang (Dato'ri): 61.

Bandjarmasin : 22, 55.

Bangsri: 7.

Bangsri (nj ag.): $5,7$.

Banju-Biru: 17.

Banju-Mas : 65, 74.

Bantam (of Bantěn), Bantammers: 35, $36,65,67,85,97,98,116,125$.

Bantěn (ad.) : 32, 84, 85.

Barros (João de) : 67.

Batavia: 103.

Batjingah (kuta) : 119, 121.

Batu Putih: 119.

Batu Renggong: 61.

Bawean: 125.

bed̦aja: = hofdanseres 50 .

Benawa (rd. of pg.) : $22,77,78,83,86$, 91-97, 99, 100.

Benawa (pg.) Jr. 99, 100, 123.

Berg (C. C.) : 61.

Beruk (kdj. ratu) : 50, 51.

Bitjak (kj.): 9, 83. 84, 127, 128. 
Blitar (pg.): 101-103.

Blora: 58, 107.

Bodjo-Nagara : 42, 48, 55.

Boeginezen : 94, 95.

Bogaert (A.) : 126.

Bolton (Willem) : 66 .

Bokong (nj. ag.) : 3 .

Bonang (sunan): 29.

Bonḍan-Kedjawan (rd.) : 5-7.

Bonḍan-Kedjawan (kj.) : 48.

Bosch (F. D. K.) : 10.

Both (g. g. P.) : 129.

Botjor : 74.

Botjor (ki) : 74, 75.

Brahmaan: 89.

Brandes (J. L. A.) : 1, 115.

Brantas : 64, 106, 118.

Brata-Juda : 94.

Bra-Widjaja : 5.

Brondong: 67.

Brouwer (D.) : 129 .

Brumund (ds. J. E. G.) : 25.

Bujut (kj.): 17.

buta: demon 41 .

Butuh: 59, 87, 89, 91.

Butuh (kj. ag.) : 17.

Çailendra: 10.

Cannae: 109.

Castioeng: $=$ Katjung (bagus) 22 .

Celebes: 61.

Cense, A. A. : 22, 55, 61.

Ceylon: 59.

China, Chinezen: 7, 95.

Cnoll, Govert: 97.

Coen (G. G. J.Pz.) : 13, 14, 42, 47).

Compagnie (Ned. O.I.) : 1, 95.

Couper (Jacob): 13, 14, 20, 47, 53, 54, 89, 114, 116.

Couto (Diego de) : 33, 58, 67, 68, 85, 126.

Crawfurd (J.) : 84 .

Daḍaptulis (aria): 50 .

Daha (= Kediri) : 62 .

dalem (= huizing): 53 .

Dalem (kuta) : 120, 121.

Dalem (sunan) : 60 .

Damar (aria) : 7

Danang of Danar (rd. bagus): 22 .

Dana-Redja : 29, 32, 47.

Dato (= datu?): 35 .

Demak of vorst van Demak: passim.

Demak (ad.) : 91-95, 98, 101, 106.

Demak (tg.) : 78, 83, 85, 91.
Demak (moskee van) : 9, 17, 24, 29, 130.

Dengkèng (kali): 127, 128.

Depok: 7.

Depok (rd.) : 7 .

Dienst (Oudheidkundige) van N.I.: 43.

Dinaja: 10.

Dipa-Nagara : 46.

Djaba (kuța) = Jogja-Karta? 120, 121.

Djaga-Pati : 6, 20, 42.

Djaga-Raga: 102, 117, 118.

Djajadiningrat (H.) : 13, 82.

Djakarta : 116.

Djaja Lengkara (Pandji) : 59.

Djaja-Raga (= Djaga-Raga) : 102 .

Djaja-Taka: 108.

Djaka Tingkir: $8,11,12,16-18,24,25$, $27,31,75,82$.

Djalu (ratu) : 117 .

Djamiloe (perdana): $36,37$.

Djapan (= Madja-Kerta): 62, 104, 111, 117.

Djapara (pg.) : 35, 36 .

Djapara (ratu) : vorstin van Japara 35.

Djapara: $27,32-37,43,55,67,111,125$, 126, 129, 132.

Djapara (pangéran van): 37 .

Djapara (vorstin van) : $30,32,35,36,68$, 125.

Djati (nj. ag.) : 5 .

Djati-Djadjar: 81.

Djati-Sari : 123.

Djedjanggu (kènțol) : 117, 122.

djempana (of tandu) : 49.

Djenar: 129.

Djenggot (mas): 88.

djim's : $=$ geesten 82 .

Djimawal : 90 .

Djipang: = Bodjo-Nagara 13, 24, 26, 32, $39,40,42-44,48,53,55,58,91-94,114$, 130.

Djipang (aria): = pg. aria Panangsang $28,31,38$.

Djoero: 66.

Djohor: 33.

Djolang: (rd.) 128.

Djuana: 67, 68.

Djulig (rd. mas) : 111.

Djumilah (rd. aju): 111.

Djuminah (pg. ad.): 101, 103, 111, 112.

djuru-kuntji: 75, 85.

Djuru-Martani (kj.) : 19-21, 39-41, 44, 50, $70,72,75,76,79,82,83,88$.

Djuru-Taman: 77, 87-89.

dodot: = statiekleed 30 . 
Drake (sir Francis) : 67.

Engelhardt (gouv. Nic.) : 3 .

Engelsen: 98.

Europeaan: 77, 89.

Filet (P. W.) : 11.

Flines (E. W. van Orsoy de): 18 .

Gadja Boemi : 99.

Gadjahwong: (kali) 120.

Gagak Rimang : 39, 41.

Gagak Pranala (pg.) : 100.

Gagak Baning (pg.): 99, 100.

Gadja Boemi: 99.

Gala Gandjur: gamelan: 78, 79.

Gambiran: 121.

Gapoera : 25.

garebeg mulud: $=$ groot feest 10 .

Garendi (mas) : 59.

Gațaju (kj.) : 96.

Geḍé (kuța) : 119, 120.

Gedéng Sura (of Gedéng Soera) : 65, 66 .

Geḍong (kj.) : 94, 95.

Gending (dip.): 121.

Genḍing (bupati) : 122 .

Genootschap (Kon. Bataviaasch): 1, 3, 4, $64,65$.

Getas : 7.

Getas Pandawa: 5-7

Giri : 37, 59-64, 95, 98, 102, 104, 105.

Giri (Radja): 37, 61.

Giri (sunan): 45, 52, 53, 60, 62, 63, 104$107,124,131$.

Giring: 51.

Giring (kj. gedé of ag.) : 51, 52.

Goens (g.g. Rijklof v.): 47, 77, 116.

Graeff (Nicol. de) : 126.

Gresik, Grissee : 57, 58, 60, 67.

Grobogan: 7, 8, 12, 194.

Gumarang: 110.

Gundil (kj.) : 109.

Gunung Djati (sunan) : 47, 115, 116.

Haan (dr. F. de) : 115.

Haan (dr. H. de) : 88, 119, 120.

Hageman (J.) : 4, 54, 57, 58, 61-64, 66, $89,90,97-100,114,123,129$.

Hasanudin : 35.

Hative: 37.

Hitoe, Hitoeëzen : 61.

Hitoe (kapitein) : 36.

Hoëvell (ds. baron W. R. van): 11.

Hollanders : 97.
Horst (H. v. d.) : 22, 47.

Houtman, (Corn.): 98, 115.

Hurdt (Ant.) : 12 .

Ima-Giri : 120.

Indra: 10.

Indragiri : 67.

Ingalaga (pg.) : $=$ Sénapati 101.

Islam: 47, 60, 61, 74.

Italiaan: 88 .

Jakarti : 117.

Java: sparsim.

Java-oorlog: 11.

Jeruzalem : 130 .

Jipang: Djipang 114.

Jogja-Karta : 11, 12, 49, 51, 52, 55, 75, $120,121$.

Jonge (J. K. J. de) : 119, 121.

Jusup (Molana) van Bantam: 35, 36.

Kaäba : 130.

kabupaten: 126.

Kadaton: 42.

Kadjoran (rd.) : 52 .

Kali Dadung : 108, 114.

Kali-Djaga (sunan) : 12, 17, 18, 20, 27-29, 44, 45, 49-51, 76, 77, 79, 92, 108, 109.

Kali-Njamat : 27, 32, 33, 44-46, 55, 125.

Kali-Njamat (pg.) : 26, 27, 29, 30, 43, 92.

Kali-Njamat (ratu) $=$ vorstin van Japara: 29, 30, 32, 33-38, 43-45, 55, 125.

Kandadaha van Pasir: 74.

Kanitrèn (rd. mas) : 111.

Kanitèn (bupati) : 110, 113.

kapir (= ongelovige) : 66.

kaputrèn (= vrouwenverblvf) : $19,50,81$.

Karang-Lo: 49.

Karang-Lo (kj.): 49-51.

Karé (nj. ag.) : 5.

Karta (kraton): 119, 120.

Karta-Sura (kraton): 20, 89.

Karti-Masa: = Sara-Dipa 117, 122.

Kartini (rd. adjeng): 43.

Katjung (bagus) $:=$ kj. gedé Pamanahan 22.

Kawis-Guwa (pan.): 106.

Kebo-Kenanga (ki) : 16.

Kebo-Dengen (si) : 74 .

Keḍiri(ërs) : 58, 61, 62, 98, 102, 111, 113, $117,118,123,131$.

Ked̦iri (ad.) : 118.

Kedu: 73, 81.

kelir: = schut achter poort $90,119$. 
Kemalon: 127.

Kembang-Kuning: 53.

Kembang-Lampir : 44.

Kendal : 96.

Kendideng-gebergte :77, 105.

Kentjana (ratu) : 50, 51.

Kepatihan: = woning $\mathrm{v} / \mathrm{d}$ rijksbestuurder 121.

$\operatorname{Kern}$ (H.) : 19, 58.

Kern (R. A.) : 61 .

Kerta-Sana: 118.

Keyser (Pieter Dircksz.): 98.

Kidul (gunung) $:=$ Zuidergebergte 52 .

Kidul (rara) : = godin van de Zuidzee $76,79,82,83$.

Kidung Pamancangah: 61 .

klangenan: 88.

Klatèn: 13.

kobongan: = staatsielegerstede 10 .

Kotatengah : 61.

Kradjang Séla : 7

Krakal : 117.

krapjak: = wildbaan 88 .

Krapjak (pan.) : 3, 88, 120, 122, 128, 129.

kraton: 25, 53, 54, 75, 80, 89.

Krèbèt (mas) : = pan. Adi-Widjaja $16 ; 39$.

kris : $31,34,74$.

Krom (N. J.) : 11, 84.

ksatrija : = ridder, edelman 61 .

Kudus : 28, 31, 40, 62, 92, 126, 130.

Kudus (sunan): 16, 27-31, 38, 91, 105.

Kukulan (berg): 96.

kuluk: = staatsiemuts 25 .

Kuning (sunan): = mas Garendi 59.

Kunst (J.) : 79.

Kuța Dalem, Djaba, Geḍè : 120, 121.

Laksamana (demang): 34, 36, 126.

Lanang (kali): 31 .

Landsarchief te Batavia: 1.

Langsé (guwa): 76, 83, 84.

Lasem: 62.

Lawejan, Lawijan: 8, 20, 86, 87, 100.

Lawejan, Lawijan (kali) : 80 .

Lawu (gunung) : 121, 122.

Lemah Duwur (pan.): 58.

Lembu Peteng: $5,7$.

Lipura: 71, 75, 79.

Livius: 109.

Lodewijcksz (W.): 69.

Lohgawé: 89.

Lombok: 60, 61.

Lontang (mas): 111.
Lubak: 125.

Lurung Tengah (nj. ag.): 5.

Maandag: $=$ hofdag 70.

Madepandan: 66.

Madiun: 25, 55, 58, 62, 102, 106, 109,

$111-114,117,118,121-23,131$.

Madja-Kerta : 104, 106, 107, 117.

Madja-Pait: 5-7, 57, 102, 116, 125.

Madura: 55-59, 104.

Majang: 86.

Majang (tg. of ki): $50,70,80-83,86$, $87,95$.

Makam Adji : 98, 100.

Makassar: 61, 94, 95.

Malakka: 30, 33-35, 68, 98.

Malaja: 58.

Maleiers : 34 .

Manahan: 22.

Mandaraka (ad): = Djuru-Martani 70, 83, 85, 104, 105, 109, 110, 122, 127, 128.

Mandura (pg.) : 121.

Mandura-Redja (kj. dip.) : 21, 120, 121.

Mangku-Bumi (pg.) : = sultan Amengku-Buwana I van Jogja-Karta 51.

Mangku-Bumi (pg.) : 109, 112, 122, 128.

Mangku-Nagara VII (kdj. gusti) : 22.

Mangku-Nagara (kroonprins) : 129.

Mangku-Rat I (sunan): 75, 114.

Mangku-Rat II (sunan): 12, 52, 53, 59, 75.

Mangku-Rat III (sunan): 59.

Mangku-Rat IV (sunan): 76, 101.

Mantingan: 43.

Mantja-Nagara: 53, 73, 118.

Mantja-Nagara (aria of tg.): 25, 77, 78.

Mantri Geḍong: 95.

Mantri Pamadjegan: 73, 74, 79, 81, 114, 117.

Mantri Pangalasan: 77, 93, 104.

Marta-Djoeta : 37.

Marta-Laja (pg. ad.) ing Madiun: 111, $118,119,122,123$.

Marta-Nagara : 25.

Marta-Wisa: 110.

Mas (sunan) : = Mangku-Rat III 59.

Mas (pg.): 65, 66, 97, 98, 107, 117.

Masahar (kj. bujut) : 5 .

Mataram: passim.

Mataram (kj. gedé of ki ageng) : $=\mathbf{k j}$. gedé Pamanahan 14, 42, 46, 49, 51-54, 62-64, 70, 82, 131.

Mataram (aria): 39, 40, 44. 
Mataun: 40, 41.

Mataun (ki) : 39-41.

Matjan-Guguh (kj.): 96.

Medina: 130.

Mekka: 61, 130.

menara: = minaret 31 .

Menḍang Kamulan: 10, 12.

Mendjangan Bang: 44, 45.

Merapi (gunung): 7, 75, 76, 82-84.

Merbabu (gunung): 7 .

Merta-Nagara (tg.) : 71 .

Mesir : = Egypte 130.

Midden-Java : $29,57,75,76,81,102,105$, 106, 129, 132.

Minangkabauer: 61 .

Moekmin (prijaji): 24.

Molukken: $35-37$.

Moslim(s): 62, 72, 95.

Mukaram: 1e maand 104, 108, 118.

Muria (gunung): 130 .

muurbouw: 71, 76, 77, 114, 119.

Nagarakrtagama : 19.

Nawang-Sih en Nawang-Wulan: 5, 6.

Nederland (-ers) : 1, 13, 124.

Neyens (M.) : 56.

New Haven (Conn.) : 129.

Ngampèl-Denta : 56, 60 .

Ngenis (kj. ag.) : 5, 6, 8, 19-21, 86, 100.

Ngerang (kj. ag.) : 5, 6, 17.

Nglipura: $=$ Lipura 75 .

Njaykabawang: 36 .

Noord-Java : 129.

Noort (Ol.v.) : 60 .

Numbak-Tjemeng: 111.

Oendaan: 25.

Oosthoek (Java's): 37, 63.

Oost-Indië: 13, 69.

Oostkust (Java's): 3 .

Oost-Java : $55,57-59,64,67,73,102,104$ $107,114,118,119,121,122,124,132$.

Opak (kali) of Oempak: 59, 51, 76, 83, 84.

Oppolzer: 129.

Pabélan (rd.) : 80.

Padèrèsan: 51.

Padjadjaran: 13, 67.

Padjang (ad.): 127.

Padjang (dip. van): 82.

Padjang (dip.) : = pg. Gagak-Bening 99.

Padjang (pg.): zoon van bovengend. 100.
Padjang (en: vorst van Padjang) : $=\mathrm{Ki}$ Djaka-Tingkir, Adi-Widjaja passim.

Padma-Susastra (ki) : 1, 7.

Pagelèn : $=$ Bagelèn 73, 102.

pager bumi : 77.

Pakis: 7.

Pakis (nj. ag.) : 5, 7.

Pakis-Dadu (nj. ag.): 5 .

Paku (rd.): = prabu Satmata 60.

Paku-Buwana I (sunan): 59.

Paku-Buwana II (sunan) : 20.

Paku-Buwana III en IV (sunan) : 50.

Pakuntjèn: 117.

Palar: 13.

Palembang: 55, 65-67.

Palmer v/d Broek (W.): 58.

Pamanahan ( $\mathrm{kj}$. geḍé of ki ageng) : = kj. geḍe of ki ageng Mataram 5-7, 13, $16,19-23,32,38-40,44-55,62,64,100$, 111.

panakawan: := hoveling 88 .

Panangsang (pg. aria) van Djipang: 25-32, 37-41, 43, 44, 54, 55, 92, 107, 130.

Pana-Raga: 53, 58, 107, 109.

Panarukan: 16, 24, 26, 37, 56, 57.

Panḍan Arang (kj. ageng): 81.

panḍita: $=$ wijze leraar 60 .

Pandjawi (ki): 19-23, 39, 40, 41, 44, 45, 110, 111.

Pandjuwed : 21, 48.

panembahan $=$ edelman, heilige : $101,106$.

pangéran: = prins 56, 101.

Pangiri (aria): 66, 92, 98.

Panião: $=$ Padjang 68.

Parakan: 96, 99.

Parakan (sunan) : 96.

Parang-Tritis : 76.

Pararaton: 89.

Parapèn (sunan) van Giri : 60-62, 106.

paséban: plek, waar men moet opkomen 101.

Pasir : 74.

Pasisir: 125

Pasuruhan: 37, 57, 58, 61, 62, 112-114, 118, 124, 131.

Patah (rd.): 7, 66

Patanèn (nj. ag.) : 5.

Pați : 13, 25, 29, 40, 41, 44, 45, 48, 54, $55,62,68,98,104,105,107,109-111$, $117,118,123,126,127-132$.

Pați (kj. ageng) : 46.

Pați (dipati) : 110, 127, 128.

patinggi of petinggi $=$ dorpshoofd: 36 , $70,71$. 
Patut (meer): 62 .

Pekik (pg.): 56, 57, 59, 60.

penḍapa: = voorhal $19,126$.

Pengging: 16-18.

peranakans: = Indo-Chinezen 95.

peri : $=\operatorname{nimf} 82$.

Pesagi (dip.): 121, 122.

Péțak (bagus) : 112.

Philippijnen: 125.

piagem: $=$ oorkonde $45,49,53,70,71$.

Pigeaud (Th.): 9, 13, 23, 28, 53, 74, 88.

Pijper (G. F.) : 130.

Pingit: $120,121$.

Pinto (Mendes) : 16, 24, 25, 37, 56.

Pires (Tomé) : 31 .

Pisammanis : 25, 56.

Plèrèd (kraton): 54, 101.

Plèrèd (kjai) : 39-41.

Poensen (C.) : 51.

Poerbatjaraka (dr. rd. ng.): 10, 22, 50, 64, 88, 89, 100.

Pondan (Pate): 56.

pondok: 40, 93.

Portugezen : $33,34,36,37,56,61,84,85$, 98, 115.

Pragola I van Pați : 21, 41, 98, 110, 111, 127, 138.

Pragola II van Pați : 25, 41.

prajangan: =geesten 82 .

Prambanan: 78, 82-85, 127, 131, 132.

Prana-Raga: = Pana-Raga 114.

Prawata: 24, 25, 28, 32, 44, 55.

Prawata (pg. of sunan): 25-30, 92.

Priangan: 115.

Premana (rg.): 117.

Puger: 102.

Puger (pg.): 101-103, 122, 129.

Purbaja (pg.) : 102, 103, 118, 121-123.

Purna (nj. ag.) : 5.

Purwa-Dadi : 7.

pusaka's : $=$ erfstukken $9,44,45,74,83$, 84, 96, 97, 109, 127, 128.

Puspa-Kentjana: 109.

Putih (pal) : 121.

Radja Boekit of Bukit: 37, 61.

Raffles (Th. 51): 4, 9, 10, 54, 57-59, 61, $62,64,90,97,111,113,114,119,123$, 129.

Rahmat (sunan of rd.) van NgampèlDenta: 56, 57, 60 .

Randu-Gunting : 78, 94, 118.

Ranḍu-Lawang : 77, 82.
Rangga (rd.): 21, 78, 79, 128.

Rangkud: 29.

Ratu (pan.) van Tjerebon: 115.

Rawa: 117, 118.

Retna-Djumilah: 110, 111.

Ridjali : 36.

Rijksarchief in den Haag: 1, 119.

Rinkes : 115.

Roo de la Faille (P. de) : 60, 65.

Rouffaer (G. P.) : 1, 4, 19, 54, 58, 60, 64, 69, 113.

Sá (Franc. de) : 67.

Saba (njai ag. of geḍé): 5, 19.

Sabrang Kulon (pg. ad.) : 107.

Sabrang Lèr (pg.): 26.

Sadjarah Bantěn: $6,7,18,20-23,28,35$, $47,48,50,59,65,82,98,126$.

Sadjarah Dalem: 1, 7, 14, 22, 58, 59, 100, 108.

Sakèndèr: 74, 87.

Sa-Lor-ing-Pasar : 22, 70.

Samarang: 4, 68, 80, 81, 96.

Samarang (pg.): 81.

Sanjaya, Senjaya : 11, 12.

Santa Guna: 56.

santri's : = godsdienst-leerling, vrome, 105.

Sara-Dipa: 117-119, 122, 123.

Sari (ki mas) : 122.

Sasaks : 60.

Satmata (prabu) : 60 .

Schoel (W. F.) : 42.

Schrieke (B.): 10, 11, 89.

Scot (Edm.): 98.

Séda-Lèpèn (pg.) : 26, 27.

Séda-ing-Kadjenar: = Sénapati 129.

Séda-Margi : 60.

sedekah: $=$ heilmaal 91.

Sekar-Delima : 96.

Sekar-Kaduaton : 80.

sekti : = kracht 7.

Séla of Seséla (Cecela) : 7, 8, 10-12, 15, 16, 19-21, 23, 44, 107.

Séla of Seséla (kjai geḍé of ag.: 5-13, $15-19,84$.

Séla of Seséla (lieden van) : 13, 32, 37, $40,41,44,45,48,54$.

Sélaparang: 60 .

sembah : = groet 76 .

Sénapati : 16, 21-23, 41, 47, 50, 54, 66, 67,70 enz.

Sénapati-ing-Alaga Sajidin Panatagama: 70. 
Sénapati (pg.) I en II : 74.

Sénapati Keḍiri : 117-119, 121-123.

sentana: = volgeling 121 .

Sepet (rd.) : 116.

Seséla Sepuh(nj. ag.): 7.

Setoto: 32.

Serat Baron Sakèndèr: 74.

Sidaju: 56-58, 62, 67, 96.

Sida-Wini (rd.) : 99.

Singa-Sari : 13, 102.

Singa-Sari (pg.): 101-103, 109.

Sirabut: = rd. bagus Srubut 14, 22.

sitinggil: = rechtheuvel met audientiehal $4,25,95$.

slasih-bloemen: $86,87$.

Soerabaja (aria) : 66 .

Soka: 80.

Solo of Sala: 10, 22, 50.

Solo (rivier) : 42, 89.

Soré (Tjaket) kali : 31, 39, 40, 42.

Soro: 66.

Soude, Soedah, Soedoe: 42.

Speelman (g.g. Corn.) : 6, 20, 42.

Sragen: 129.

Srubut (rd. bagus) : = Sénapati 14, 22 .

Stapel (F. W.): 61.

Stutterheim (W. F.) : 10, 19, 125.

Sudaju (pati) : 25, 56.

Sumatra: 67.

Sumbawa: 56 .

Sumenep: 57.

Sunda: 67.

Sundjaja: 56.

Supanta (dip.): 122.

Sura : $65,66$.

Sura-Baja : 25, 37, 56, 57, 59, 60, 62, 63, $65,66,68,92,102,104-109,117,118$, $122,126$.

Sura-Baja (pg.): 117, 118.

Sura Geding : 65, 66.

Sura Jata: 27.

Sura-Karta (kraton): 12, 18, 51, 55, 89, 94.

Sura-Pati: 14.

Sura-Tanu: 80 .

Surja-Alam : 55.

Surja-Nagara (pg. aria): 4.

susuhunan: $24,25,66$.

Susuruh (rd.): 13.

Suta-Widjaja (rd. ng.): 22, 23, 41, 44, 45.

Tadji : 49-51, 121.

Takmung (Den): 6 . taman: $=$ tuin 88

Tambak-Baja (ki): 59.

tamtama: = lijfwacht $8,17,22,31,80$.

tandu: $=$ draagstoel 85 .

tapa: $=$ ascese $8,44,46,51,52,76,96$.

Tarub: 7, 11 .

Tarub (kj. ageng) : 5, 6, 11 .

Tegal-Wangi : 114 .

Tembajat: 52, 81, 85, 123.

Thijen (Willem v.) : 66, 67.

Timur (pg.) v. Madiun: 25, 55, 107.

Tingkir: 11, 16-18.

Tjaket (kali) : 39 .

Tirta-Wiguna (tg.) 59.

tjakal bakal: $=1 \mathrm{e}$ bewoner, ontginner $8,20$.

Tjalonțang (mas): 117.

tjaraka: 43.

tjatjah $=$ werkbare landbouwer, 46,53 , 118.

tjempaka: $=$ bloem 80 .

Tjerebon: $7,14,27,28,47,53,68,114$, 115.

Tjina (putri) : 7 .

Tjodé (kali) : 120 .

Tjoetjoe: 7 .

Tjojudan : 50 .

Tjuli (kj.) : 127 .

Toeban Besi (Perdana): 37.

Tolé (pg.) : 74.

Tompé (rd. bagus of rd.) : 99, 100.

Trenggana (sultan of pg.) : 16-18, 24, 26, $27,35,36,57,66,98,107,110$.

Truna-Djaja (rd.): 12, 58.

Tuban, -ners : 58, 62, 67, 78, 123-125, 132.

Tuban (ad. of tg.) : 77, 78, 83, 85, 86, 91.

Tunggul-Wulung: 76.

Uluk: $44,45$.

Uter: $121,123$.

Uteran: 123.

Upa-Santa (kj. dip.) : 120.

Ungaran : 81 .

Valentijn (ds. Franç.) : 13, 14, 20, 36, 47, $61,115$.

Veth (P. J.) : 64, 67.

Vorstenlanden: 11, 17.

Wana-Giri: 123.

Wana-Kerta: $=$ Padjang? 123.

Wanglu (nj. ag.): 5 .

wajang bèbèr: = prentenwajang 16 . 
Wanḍan-vrouw: 5.

Warga-Utama : 65.

waringin kurung: = omheinde war. old alun 28,70 .

Warung: 107, 108.

Weḍi : 121-123.

Weru: 93, 94.

West-Java : 14, 35, 47, 55, 132.

Wila-Marta (ng.) : 25, 71.

Winter (J. W.) : 51, 54.

Wira-Kentjana (patih) : 74.

Wira-Kerti : 80.
Wira-Menggala (pg.): 117, 118.

Wira-Merta (tg.): 71.

Wira-Redja (kj. tg.) : 50, 51 .

Wira-Saba: 58, 62, 64, 65, 110, 117.

Wiratmaka (kjai) : 111 .

Wirja-Krama (Pandji): 59, 60, 63

Wiselius (J. A. B.) : 60, 106.

Wuragil (ng.) : 71 .

Zuidergebergte : 82-84, 93, 94.

Zuidzee: 75, 76, 85. 


\section{INHOUD.}

Inleiding . . . . . . . . . . . . . . . . . . . . 1

De belangrijkste Javaanse bronnen. . . . . . . . . . . 3

Kjai gedé Séla . . . . . . . . . . . . . . . . . 5

De oudste stamboom . . . . . . . . . . . . . . 5

Kjai geḍe Séla volgens de overlevering . . . . . . . . 8

Het vuurceremonieel . . . . . . . . . . . . . 10

De Séla-traditie en Mataram . . . . . . . . . . . 12

Oudste Nederlandse berichten . . . . . . . . . . . 13

De lieden van Séla in Padjang . . . . . . . . . . . . . 16

Overleveringen omtrent Djaka-Tingkir . . . . . . . . 16

Padjangse oudheden . . . . . . . . . . . . . . 18

De verhuizing van Ngenis . . . . . . . . . . . . 19

De drie mannen van Séla . . . . . . . . . . . . 21

De worsteling tussen Djipang en Padjang . . . . . . . . 24

Padjang's eerzucht . . . . . . . . . . . . . . 24

Djipang's wraakzucht . . . . . . . . . . . . . . 26

Het ingrijpen der heiligen . . . . . . . . . . . . 27

De drie moordaanslagen . . . . . . . . . . . . . 29

Het evenwicht in Kudus . . . . . . . . . . . . . 31

Djapara's rol . . . . . . . . . . . . . . . . . . 32

De ratu Kali-Njamat . . . . . . . . . . . . . . 32

Djapara's aanvallen op Malakka . . . . . . . . . . 33

Djapaarse tochten naar Bantam en de Molukken . . . . 35

Djapara en het binnenland . . . . . . . . . . . . 37

De beslissende strijd. . . . . . . . . . . . . . . . 39

De overwinning op Djipang . . . . . . . . . . . . . 39

Nederlandse berichten omtrent de strijd Padjang-Panangsang 42

Datering van Djipang's val . . . . . . . . . . . . 43

De beloning der lieden van Séla . . . . . . . . . . . . 44

Toekenning van Pați en Mataram . . . . . . . . . 44

De mogelijkheid ener verovering van Mataram . . . . . 47

Kjai gedé Mataram . . . . . . . . . . . . . . . . 49

Karang-Lo . . . . . . . . . . . . . . . . . 49 
Giring . . . . . . . . . . . . . 51

Verblijf in Mataram . . . . . . . . . . 52

Datering der stichting van Mataram . . . . . . . . 54

Padjang in de Oosthoek . . . . . . . . . . . . . . 55

Omvang van het Padjangse rijk . . . . . . . . 55

„Pate Sudayo" van Sura-Baja . . . . . . . . . . . 56

Lemah Duwur van Madura . . . . . . . . . . . 57

Padjang's zege over Oost-Java . . . . . . . . . . 58

Sunan Parapèn van Giri . . . . . . . . . . . . . 60

Padjang's reis naar Giri . . . . . . . . . . . . . 62

Padjang verovert Wira-Saba . . . . . . . . 64

De eerste vorst van Palembang . . . . . . . . . 65

Padjang's hoogtepunt . . . . . . . . . . . . . 67

Eerste drie jaren van Sénapati . . . . . . . . . . . . 70

Sénapati's aanstelling. . . . . . . . . . 70

Sénapati blijft weg. . . . . . . . . . . . . . 71

Sénapati wint aanhangers . . . . . . . . . 72

Sénapati ondergaat wijdingen . . . . . . . . . . . 75

Het tweede Padjangse gezantschap . . . . . . . . . 77

Samenvatting der eerste drie jaren . . . . . . . . $7 \mathrm{~S}$

Sénapati verovert de kraton Padjang . . . . . . . . . . 80

De aanleiding tot de oorlog. . . . . . . . . . . . 80

De slag bij Prambanan . . . . . . . . . . . . . 82

Sultan Padjang's wijken naar Bajat. . . . . . . . . 85

De vervolging door de Matarammers . . . . . . . 86

De dood van sultan Padjang . . . . . . . . . . 87

Het Demakse tussenspel . . . . . . . . . . . . . . . . . 91

De twist over de opvolging . . . . . . . . . . . . 91

Adipati Demak is vorst van Padjang . . . . . . . . 92

Sénapati en Benawa veroveren Padjang . . . . . . . 94

De verdwijning van pg. Benawa . . . . . . . . . . 96

Ondergang van Demak . . . . . . . . . . . . . 97

Padjang tot zijn ondergang in 1617 . . . . . . . . . 99

Sénapati's verheffing tot panembahan . . . . . . . 101

Sénapati's strijd om de leiding. Voorspoed . . . . . . . . 104

De tocht naar Madja-Kerta . . . . . . . . . . 104

Afval en verovering van Madiun . . . . . . . . . . 107

De strijd met Pasuruhan . . . . . . . . . . . . . 112

Sénapati in het Westen . . . . . . . . . . . . . 114 
Sénapati's strijd om de leiding. Tegenspoed . . . . . . . . 117 Het overlopen der Kediriërs . . . . . . . . . . . 117

Sénapati Kediri als bouwmeester . . . . . . . . . . 119

Sénapati Keḍiri sneuvelt bij Uter . . . . . . . . . 121

De aanvallen op Tuban . . . . . . . . . . . . . 123

Ondergang van Kali-Njamat . . . . . . . . . . . 125

De opstand van Pați . . . . . . . . . . . . . 127

Sénapati's dood . . . . . . . . . . . . . 128

Datering van Pați's opstand en Sénapati's dood . . . . . 129

Samenvatting . . . . . . . . . . . . . . . 131

Jaartallenlijst . . . . . . . . . . . . . . . . 133

Stambomen. . . . . . . . . . . . . . . 134-135

Bibliographie . . . . . . . . . . . . . . 136

Alphabetisch Register . . . . . . . . . . . . . . . 139 